\title{
New approaches for immune modulation in Myasthenia Gravis
}

Citation for published version (APA):

Phernambucq, M. A. (2009). New approaches for immune modulation in Myasthenia Gravis. [Doctoral Thesis, Maastricht University]. Universitaire Pers Maastricht. https://doi.org/10.26481/dis.20091209mp

Document status and date:

Published: 01/01/2009

DOI:

10.26481/dis.20091209mp

Document Version:

Publisher's PDF, also known as Version of record

\section{Please check the document version of this publication:}

- A submitted manuscript is the version of the article upon submission and before peer-review. There can be important differences between the submitted version and the official published version of record.

People interested in the research are advised to contact the author for the final version of the publication, or visit the DOI to the publisher's website.

- The final author version and the galley proof are versions of the publication after peer review.

- The final published version features the final layout of the paper including the volume, issue and page numbers.

Link to publication

\footnotetext{
General rights rights.

- You may freely distribute the URL identifying the publication in the public portal. please follow below link for the End User Agreement:

www.umlib.nl/taverne-license

Take down policy

If you believe that this document breaches copyright please contact us at:

repository@maastrichtuniversity.nl

providing details and we will investigate your claim.
}

Copyright and moral rights for the publications made accessible in the public portal are retained by the authors and/or other copyright owners and it is a condition of accessing publications that users recognise and abide by the legal requirements associated with these

- Users may download and print one copy of any publication from the public portal for the purpose of private study or research.

- You may not further distribute the material or use it for any profit-making activity or commercial gain

If the publication is distributed under the terms of Article $25 \mathrm{fa}$ of the Dutch Copyright Act, indicated by the "Taverne" license above, 
New approaches for immune modulation in Myasthenia Gravis 
Copyright CMarko Alexander Phernambucq, Maastricht 2009 ISBN 9789052789002

New approaches for immune modulation in Myasthenia Gravis

Cover: Drawing of different species of electric rays. Torpedo marmorata and Torpedo californica were used in this research for the isolation of the acetylcholine receptor, derived from the electric organ of these fish.

All rights reserved. No part may be reproduced or transmitted in any form or by any means, electronic or mechanical including photocopying, recording or by any information storage and retrieval system, without permission, in writing, from the copyright holder.

Typesetting and layout: Marko Phernambucq and Datawyse, University Press Maastricht 


\title{
New approaches for immune modulation in Myasthenia Gravis
}

\author{
Proefschrift \\ Ter verkrijging van de graad van doctor aan de Universiteit Maastricht \\ op gezag van de Rector Magnificus, Prof. Mr. G.P.M.F. Mols \\ volgens het besluit van het college van Decanen \\ in het openbaar te verdedigen op woensdag 9 december 2009 om 16.00 uur \\ door \\ Marko Alexander Phernambucq \\ geboren 10 augustus 1979 te Goes
}

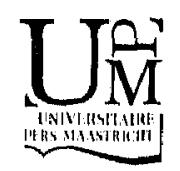




\section{Promotor}

Prof. dr. M. H. De Baets

\section{Copromotoren}

Dr. M. Losen

Dr. P. Martinez-Martinez

\section{Beoordelingscommissie}

Prof. dr. H. Steinbusch

Dr. P. Molenaar

Prof. dr. J. Weis

Prof. dr. V. Somers 


\title{
Abbreviations
}

\author{
$\alpha$-BT $\quad \alpha$-bungarotoxin \\ Ach acetylcholine \\ AChR acetylcholine receptor \\ BN rat brown norway rat \\ CFA complete freund's adjuvant \\ CMAP compound muscle action potential \\ CMS congenital myasthenic syndrome \\ CTLA-4 cytotoxic t-lymphocyte antigen 4 \\ EMG electromyography \\ EAMG experimental autoimmune myasthenia gravis \\ ELISA enzyme-linked immunosorbent assay \\ Fab antigen-binding fragment \\ IVIg intravenous immunoglobulin \\ MAC membrane attack complex \\ mAb monoclonal antibody \\ $M G$ myasthenia gravis \\ MIR main immunogenic region \\ MMF mycophenolate mofetil \\ MuSK muscle-specific kinase \\ NMJ neuromuscular junction \\ PBS phosphate buffered saline \\ RIA radioimmunoassay \\ shRNA short hairpin RNA \\ tAChR torpedo californica acetylcholine receptor \\ VAChT vesicular acetylcholine transporter \\ VGSC voltage gated sodium channel
}




\section{Contents}

Introduction

Chapter 1 Immunosuppression of Experimental Autoimmune Myasthenia

Gravis by Mycophenolate Mofetil

Chapter 2 Immunomodulatory effect of the dual altered peptide ligand PTR262 in experimental autoimmune myasthenia gravis in rats

Chapter 3 CTLA-4 polymorphisms are not associated with myasthenia gravis in Dutch patients.

Chapter 4 Silencing rapsyn in vivo decreases acetylcholine receptors and augments sodium channels and secondary postsynaptic membrane folding

Chapter 5 Prevention of acetylcholine receptor modulation in myasthenia gravis

Chapter 6 General discussion

List of publications

Acknowledgements

Curriculum Vitae 


\section{Introduction}

The immune system is a complex system which protects organisms from infection with layered defenses of increasing specificity. This specificity is necessary, not only to defend against and precisely target pathogens, but also to prevent this system from attacking and damaging the body's own tissues. Tolerance against selfantigens is a process which is established by positive and negative selection of $T$ cells in the thymus. In many autoimmune diseases, tolerance against self-antigens is lost, resulting in an immune response with a sometimes severe pathology.

The neuromuscular junction (NMJ) in particular is a target for a variety of immunological disorders. Antibodies directed to several targets in the NMJ cause numerous autoimmune-associated diseases which occasion some degree of muscle malfunctioning. Lambert-Eaton myasthenic syndrome (LEMS) is caused by antibodies directed against voltage gated calcium channels on the pre-synaptic membrane of the NMJ. Inhibition of the voltage-gated calcium channels prevents acetylcholine from being released from the pre-syntaptic terminal, and the subsequent stimulation of the post-synaptic terminal which would lead to muscle contraction (Lennon, Kryzer et al 1995). Another NMJ-targeted autoimmune disease is acquired neuromyotonia (NMT), a condition associated with muscle hyperactivity (Hart 2000). NMT patients are characterized by antibodies directed against the voltage-gated potassium channels (Vincent, Jacobson et al 1998).

Finally, there is myasthenia gravis, an almost prototypical example of an antireceptor antibody-mediated autoimmune disease caused by autoantibodies (Drachman 1994). Myasthenia gravis is characterized by the failure of neuromuscular transmission, which results from the binding of autoantibodies to proteins involved in signaling at the neuromuscular junction (NMJ). Most of these autoantibodles are directed against the acetylcholine receptor (90\%) or against the Muscle Specific Kinase (MUSK). In another $5 \%$ of patients, the specificity of the antibodies is unknown.

Currently many different therapies are available for MG patients, which all interact with a different aspect of $M G$. Immunosuppressive drugs like azathioprine, corticosteroids, cyclosporine A, tacrolimus, etanercept, and cyclophosphamide are the most common therapeutic agents used to treat $M G$. These immunosupressants cause considerable improvement in clinical symptoms among $80 \%$ of patients. The 
drawbacks of the above mentioned drugs are their serious side effects, which affect the quality of life, and their unpredictable or long onset before becoming clinically effective. Therefore we wish to explore and to list new approaches towards a more effective treatment of MG.

In Chapter 1, we test a potential new therapeutic agent for MG, which may have fewer side effects and induce a faster treatment effect. Mycophenolate mofetil (MMF) is an immunosuppressant, which is used to treat a wide variety of autoimmune diseases, including rheumatoid arthritis, lupus nephritis, Wegener's granulomatosis and some other autoimmune diseases. Furthermore it is effective in preventing rejection of transplanted organs. MMF operates through reduction of intracellular purine synthesis in both B- and T-lymphocytes, leading to inhibition of lymphocyte proliferation; consequently it acts as a pluripotent immunomodulator (Schneider-Gold, Hartung et al 2006).

In this chapter, we describe the treatment of Lewis rats with Experimental Autoimmune Myasthenia Gravis (EAMG) with MMF.

In Chapter 2, we tested a different type of potential treatment. We investigated if, and by which mechanism, an altered analog of two myasthenogenic peptides, p195-212 and p259-271, representing sequences of the acetylcholine receptor $\alpha$ subunit, is able to modulate the autoimmune response in EAMG rats. This approach to treating $M G$ is totally different from classical therapeutic MG drug, in the sense that instead of suppressing the immune response in MG, PTR 262 only alters the immune response to create a non-pathological response. We tested PTR262 in EAMG rats in a comparable experiment as was done with MMF.

In Chapter 3, we investigated if CTLA-4 polymorphisms are associated with MG. The CTLA-4 (CD152) gene at chromosome $2 q 33$ is expressed on the surface of activated T-celis, It plays an important role in the regulation of the immune response. Previous studies showed that CTLA-4 polymorphisms are associated with several autoimmune diseases. To study the association of genetic heterogeneity of the CTLA-4 gene in more detail, we determined $-1722 \mathrm{C} / \mathrm{T},-1661 \mathrm{~A} / \mathrm{G},-318 \mathrm{C} / \mathrm{T}$, and +49 $A / G$ genotypes of 97 Dutch patients with seropositive $M G$.

In Chapter 4, we studied the effect of silencing receptor-associated proteins of the synapse (rapsyn). The acetylcholine receptor ( $A C h R$ ) is clustered at high density in the postsynaptic membrane by rapsyn. Because rapsyn is crucial for the stabilization of the AChR, it might also play a role in the autoimmune disease myasthenia gravis (MG), where auto-antibodies against the AChR reduce the number of functional AChRs at the postsynaptic membrane. In order to obtain further insight into the role of rapsyn in adult muscle, we studied the effect of down-regulation of ran psyn by RNA interference (RNAi). Muscles in adult rats were transfected by in vivo electroporation using the mammalian expression vector PSUPER that directs the synthesis of short hairpin RNA (shRNA) transcripts. In this chapter, we explore ra- 
psyn's pivotal role in the postsynaptic folding and maintenance of the AChR in the NMJ of adult muscle.

The anchor protein rapsyn also plays a key part in Chapter 5. In MG, pathogenic antibodies reduce the number of receptors by antigenic modulation and complement activation. The importance of antigenic modulation in the disease was demonstrated in a rat EAMG model using the AChR clustering protein rapsyn. We tested whether rapsyn overexpression was able to prevent AChR modulation by bivalent antibodies. Furthermore, we tested if functionally monovalent $\lg G 4$ antiacetylcholine receptor antibodies could prevent damage to the postsynaptic membrane by preventing antigenic modulation, so we could investigate the possibility of preventing antigenic modulation as a promising therapeutic strategy for the treatment of MG.

\section{References}

Drachman, D.B., 1994. Myasthenia gravis, N Engl J Med 330, 1797-1810.

Hart, I.K., 2000. Acquired neuromyotonia: a new autoantibody-mediated neuronal potassium channelopathy. Am J Med Sci 319, 209-216.

Lennon, V.A., Kryzer, T.J., Griesmann, G.E., O'Suilleabhain, P.E., Windebank, A.J., Woppmann, A., Miljanich, G.P., Lambert, E.H., 1995. Calcium-channel antibodies in the Lambert-Eaton syndrome and other paraneoplastic syndromes. N Engl J Med 332, 1467-1474.

Schneider-Gold, C., Hartung, H.P., Gold, R, 2006. Mycophenolate moletil and tacrolimus: new therapeutic options in neuroimmunological diseases. Muscle Nerve 34, 284-291.

Vincent, A., Jacobson, L., Plested, P., Polizzi, A., Tang, T., Riemersma, S., Newland, C., Ghorazian, S., Farrar, J., MacLennan, C., Willcox, N., Beeson, D., Newsom-Davis, J., 1998. Antibodies affecting ion channel function in acquired neuromyotonia, in seropositive and seronegative myasthenia gravis, and in antibody-mediated arthrogryposis multiplex congenita. Ann N Y Acad Sci 841, 482-496. 


\section{Chapter 1}

\section{Immunosuppression of Experimental}

Autoimmune Myasthenia Gravis by Mycophenolate Mofetill

Sofie P.M. Janssen*, Marko Phernambucq*, Pilar Martinez-Martinez, Marc H. De Baets and Mario Losen

* Both authors equally contributed to this research 
CHAPYER 1

Abstract

Currently used non-specific immunosuppressive drugs often require intervention in myasthenia gravis (MG) and clinical improvement varies widely. To analyze the therapeutic effect of mycophenolate mofetil (MMF) in experimental autoimmune MG (EAMG), rats were immunized with acetylcholine receptors (AChRs) and subsequently treated with MMF or vehicle. MMF treatment resulted in a significant suppression of anti-rat AChR antibody titers. Interestingly, no abnormalities of neuromuscular transmission and adverse side-effects were detected in MMF-treated EAMG animals. Moreover, anti-rat AChR antibody titers correlated to an improvement of clinical outcome. In conclusion, our data suggest that MMF acts as a potent immunosuppressant drug in EAMG. 


\section{Introduction}

Myasthenia gravis (MG) is a potentially life-threatening but treatable organ specific autoimmune disorder, characterized by weakness and fatigability of voluntary muscles, i.e. ocular, bulbar, limb and respiratory muscles. In about $85 \%$ of patients (Lindstrom et al., 1976d), autoantibodies against the nicotinic acetylcholine receptor $(A C h R)$ in the postsynaptic membrane of the neuromuscular junction are responsible for these symptoms, and have been shown to destroy neuromuscular transmission by different mechanisms: cross-linking of AChRs leading to increased AChR turnover, functional blockade of the acetylcholine-binding sites, complementmediated damage to the postsynaptic membrane (Drachman, 1994), and destruction of proteins involved in neuromuscular formation (Martinez-Martinez et al., 2007). Moreover, autoantibodies that bind to the muscle specific protein kinase (MUSK), are present in a subgroup of patients with MG who do not have antibodies against the AChR (Hoch et al., 2001).

Currently many therapies are available for $M G$ patients, all intervening with different targets of the disease. Thymectomy is nowadays a widely accepted and practiced form of treatment for MG and is performed in an attempt to induce complete remission or to reduce long-term need for immunosuppression (Gronseth and Barohn, 2000). In contrast, anti-cholinesterase agents are frequently used in the early disease course to decrease MG symptoms as they inhibit acetylcholine esterase from hydrolyzing acetylcholine. The prolonged exposure time of acetylcholine to AChRs in turn leads to improved neuromuscular transmission and muscle strength, however without affecting the autoimmune attack itself (Richman and Agius, 2003). Intravenous immunoglobulin (Gajdos et al., 2006) and plasmapheresis (Gajdos et al., 2006; Lehmann et al., 2006) are mostly temporary treatments used to produce rapid improvement during myasthenic crises or acute exacerbations. Finally, long-term immunosuppressives like corticosteroids, azathioprine, cyclosporine A, tacrolimus, rituximab, etanercept, leflunomide and cyclophosphamide are nowadays considered to be the most consistently effective and easily usable therapeutic agents as they induce improvement in approximately $80 \%$ of patients. However, the onset of clinical improvement varies widely among these immunosuppressive agents and side effects are often very severe due to toxicity of the therapeutics (Ciafaloni, 2005; Garcia-Carrasco et al., 2007; Sieb, 2005). Currently, the best evidence based immunosuppressive therapy for $M G$ is the combination of prednisone with azathioprine. This combined treatment allows a reduction of required prednisone and concomitantly reduces, albeit incompletely, side effects such as malaise, back pain, visual deterioration, and rash (Palace et al., 1998). From this point of view, new effective and safe immunosuppressive drugs for MG patients are urgently required. 
Mycophenolate mofetil (MMF) is a potent immunosuppressive drug that was primarily licensed to prevent rejection of transplanted organs (European Mycophenolate Mofetil Cooperative Study Group, 1995) and then introduced for the therapy of autoimmune diseases of skin (Enk and Knop, 1997), gut (Neurath et al., 1999), and eye (Larkin and Lightman, 1999), in rheumatoid arthritis (Goldblum, 1993), lupus nephritis (Ginzler et al., 2005) and Wegener's granulomatosis (Nowack et al., 1999). In the last decennium it has also been used in patients with neuromuscular diseases like inflammatory myopathy and chronic inflammatory demyelinating polyradiculoneuropathy to achieve either symptom stabilization or remission (Chaudhry et al,, 2001). MMF operates through reduction of intracellular purine synthesis in both $B$ and T-lymphocytes, leading to inhibition of lymphocyte proliferation. Moreover, MMF does not only augment apoptosis of lymphocytic and monocytic cell lines (Cohn et al., 1999) and reduces the levels of immunoglobulin isotypes $M, G$ and $A$ produced by polyclonal activated B-lymphocytes (Eugui et al., 1991), it also inhibits glycosylation of adhesion molecules (Blaheta et al., 1998) and regulates the secretion of inflammatory and anti-inflammatory cytokines (Durez et al., 1999). Consequently, MMF acts as a pluripotent immunomodulator in numerous types of immunological diseases (Schneider-Gold et al., 2006).

The successful use of MMF in MG has already been described in several small clinical trials, with the main advantage of MMF being its tolerability and safety profile (Caponnetto et al., 2001; Chaudhry et al., 2001; Ciafaloni et al., 2001; Hauser et al., 1998; Lim et al., 2007; Meriggioli et al., 2003a; Meriggioli et al., 2003b; Mowzoon et al., 2001; Prakash et al., 2007; Schneider et al., 2001). However, data from 2 recently completed large phase 3 prospective, multi-center, placebo-controlled trials showed only little or no effect of the drug when used as an adjunctive treatment to corticosteroids (Hampton, 2007; Sanders et al., 2008; The Muscle Study Group, 2008). This suggests that further studies are needed to assess the benefits of MMF as primary or long-term therapy and therefore encourages the examination of its precise mechanism in an experimental animal model of MG.

Experimental autoimmune myasthenia gravis (EAMG) in rats induced by immunization with AChRs from the electric organ of Electrophorus electricus or Torpedo californica, is already known for decades to be a reproducible and characteristic chronic model of MG. Indeed, the presence of antibodies directed to rat muscle AChRs in the circulation of rats with EAMG provides evidence for the existence of autoimmunity in this experimental disease model. Moreover, similar to MG, antigenic modulation and complement-mediated focal damage of the postsynaptic membrane are the main pathogenic mechanisms that lead to muscular weakness, hunched posture, weight loss and electrophysiological abnormalities in these animals, and can be relieved by anti-cholinesterases (Lennon et al., 1975). For these reasons, EAMG in rats is an excellent model to examine the therapeutic effect of MMF. 


\section{Materials and Methods}

\section{Animal model}

Eight-weeks old female Lewis rats were obtained from the Department of Experimental Animal Services, University of Maastricht, The Netherlands, with permission of the Committee on Animal Welfare, according to Dutch governmental rules.

For immunization and intubation, rats were anesthetized by inhalation of $3-5 \%$ isoflurane in air enriched with $50 \%$ oxygen, supplied by a cylindrical cap held over the head. Euthanasia was performed by $\mathrm{CO}_{2} /$ air inhalation and subsequent cervical dislocation.

\section{Induction of chronic EAMG}

Animals were immunized at the base of the tail with $10 \mu \mathrm{g}$ Torpedo californica AChR (tAChR) in $0.1 \mathrm{~mL}$ of phosphate-buffered saline (PBS), emulsified in an equal amount of Freund's adjuvant with $0.1 \%$ Mycobacterium tuberculosis (Difco Laboratories, Detroit, USA) (Lennon et al., 1975). Blood samples were taken weekly from the vena saphena magna to measure anti-rat $A C h R$ antibody titers. Sham-immunization was performed under similar conditions using $0.1 \mathrm{~mL}$ of PBS and an equal volume of Freund's adjuvant with $0.1 \%$ Mycobacterium tuberculosis (Lennon et al., 1975).

\section{Administration of immunosuppressive drugs}

Mycophenolate mofetil (MMF; Roche Palo Alto LLC, California) was administered orally at a dose of $30 \mathrm{mg} / \mathrm{kg} /$ day in a $900 \mu \mathrm{L}$ autoclaved vehicle solution consisting of distilled water, $0.9 \%$ benzyl alcohol, $0.4 \%$ polysorbate $80,0.9 \%$ sodium chloride, $0.5 \%$ carboxymethylcellulose and $5.0 \%$ sucrose $(\mathrm{pH} 3.5)$.

\section{Experimental design}

Two different treatment regimes of MMF were investigated using 62 rats in total. For the first treatment regime, two groups of rats immunized with $t A C h R$ were given either vehicle (vehicle-treated EAMG rats, $n=10$ ) or MMF (MMF-treated EAMG rats, $n=10$ ) daily for 3 weeks, starting at the time of immunization, and were compared to sham-immunized controls $(n=10) 8$ weeks after immunization. For this series in particular, immunohistochemical analyses were performed together with determination of total muscle AChR content.

For the second treatment regime, two groups of rats immunized with $t A C h R$ received either vehicle (vehicle-treated EAMG rats, $n=18$ ) or MMF (MMF-treated rats, $n=10$ ) daily for 8 weeks, starting at the time of immunization. Four sham- 
CHABTEA

immunized rats were used as controls and were compared to the above-mentioned groups 8 weeks after immunization. More precisely, electromyographic measurements (EMG) during continuously intravenous curare infusions to induce decrement of compound muscle action potentials (CMAP) were performed.

For all rats, the body weights, clinical scores and anti-rat AChR antibody titers were measured regularly.

\section{Clinical scoring}

The severity of clinical signs in EAMG was scored weekly by measuring rats' muscular weakness through assessing their ability to grasp and lift repeatedly a 300 -g rack from the table while suspended manually by the base of the tail for 30 seconds (Hoedemaekers et al., 1997a). Clinical scoring was based on the presence of tremor, hunched posture, muscle strength and fatigability. Disease severity was expressed as 0 , no obvious abnormalities; I, no abnormalities before testing but reduced strength at the end; II, clinical signs present before testing i.e. tremor, hunched posture, head down, weak grip; III, severe clinical signs present before testing, no grip, moribund (Lennon et al., 1975).

\section{Measurement of serum anti-rat AChR antibody titers}

Anti-rat AChR antibody titer measurements were carried out at $4^{\prime \prime} \mathrm{C}$ by a doubleantibody radioimmunoassay (RIA) as described previously (Losen et al., 2005; Martinez-Martinez et al., 2007). Briefly, antibodies directed against rat AChRs were measured using a crude extract of denervated rat muscle (approximately $5 \mathrm{nmol} / \mathrm{L}$ AChR), labeled with an excess of ${ }^{2.5} \mathrm{l}$ - $\alpha$-bungarotoxin (IM109, $6.12 \mathrm{TBq} / \mathrm{mmol}, \mathrm{GE}$ Healthcare, Amersham Place, UK), and incubated overnight with $5 \mu \mathrm{L}$ rat test serum. Precipitation was induced by addition of $100 \mu \mathrm{L}$ goat anti-rat IgG serum, followed by 3 washing steps in PBS with $0.5 \%$ Triton $X-100$. Radioactivity counts were measured in a $\gamma$-counter (1480 Wizard 3", PerkinElmer, USA) and corrected for background measurements using normal rat serum. Antibody titers were expressed as nmoles of $a$-bungarotoxin binding sites/L.

\section{Immunohistochemical staining}

Left tibialis anterior muscles were frozen in isopentane cooled with liquid nitrogen to perform immunohistochemical staining as described previously (Losen et al., 2005; Martinez-Martinez et al., 2007) with the follawing modifications: $10 \mu \mathrm{m}$ cryosections were incubated with mouse anti-rapsyn mAb 1234 (1:500 in PBS with 2\% bovine serum albumin (PBSA), Sigma, USA), rabbit anti-vesicular acetylcholine transporter (VAChT-1:500 in PBSA, Sigma, USA), and Alexa 594-conjugated $\alpha$ - 
bungarotoxin (1:300 in PBSA, Molecular Probes, USA) for 1 hour. Subsequently, sections were incubated for 45 minutes with the appropriate secondary antibodies: biotinylated goat anti-mouse IgG (1:400 in PBSA; Jackson immunoresearch, USA) and Alexa 350-conjugated goat anti-rabbit (1:100 in PBSA; Molecular Probes, USA). Finally, the biotinylated secondary antibody was stained for 30 minutes with Alexa 488-conjugated streptavidin (1:2000 in PBSA; Molecular Probes, USA). All incubation steps were performed at room temperature.

\section{Immunofluorescence microscopy}

Pictures of triple stained muscle sections were taken using a Provis AX70 fluorescent microscope (Olympus, Hamburg, Germany) connected to a black and white digital video camera (U-CMAD-2, Olympus), equipped with AnalySIS software (Soft imaging Systems, Münster, Germany). All microscope settings were maintained constant during photographing, with the exposure time of the camera set to values that prevent saturation. Pictures were subsequently analyzed using Imagel software (version 1.37k; http://rsb.info.nih.gov/ij/). Neuromuscular junctions were identified as regions with presynaptic VAChT staining.

\section{Measurement of total muscle AChR}

The right tibialis anterior muscle of each rat was minced and homogenized with an Ultra-Turrax ( 3 times 30 seconds at $4^{\circ} \mathrm{C}$ ) in $10 \mathrm{~mL}$ extraction buffer (PBS mixed with $10 \mathrm{mM}$ sodium azide, $10 \mathrm{mM}$ ethylenediaminetetraacetic acid, $10 \mathrm{mM}$ iodoacetamide, and $1 \mathrm{mM}$ phenylmethyl sulfonyl fluoride). The homogenate was centrifuged at $22100 \mathrm{~g}$ for 30 minutes at $4^{\circ} \mathrm{C}$ and the resulting pellet was resuspended in $2.5 \mathrm{~mL}$ extraction buffer with an additional $2 \%$ Triton X-100. Extraction was performed on a reciprocal shaker for 1 hour at $4^{\circ} \mathrm{C}$, followed by centrifugation at $22100 \mathrm{~g}$ for 30 minutes at $4^{\circ} \mathrm{C}$. AChR concentrations were then measured by RIA using an access of ${ }^{13 \mathrm{k}} \mathrm{l}-\alpha$-bungarotoxin (IM209, $74 \mathrm{TBq} / \mathrm{mmol}$, GE healthcare, Amersham Place, UK) as described previously (Losen et al., 2005). Total muscle membrane AChR concentration was calculated per $g$ of fresh muscle and thus expressed in $\mathrm{fmol} / \mathrm{g}$.

\section{Electromyography}

Decrement of CMAP during repetitive nerve stimulation was measured during concurrently continuous curare (D-tubocurarine chloride, ICN Biomedicals, Illkirch France) infusions in left tibialis anterior muscles of rats 8 weeks after immunization using the EMG system Viking IV (Nicolet Biomedicals Inc., Madison, USA) as previously described (Losen et al., 2005; Martinez-Martinez et al., 2007; Seybold et al., 
1976) with the following modifications: curare infusions (Terfusion syringe pump, model STC-521, Terumo, Japan; $1 \mathrm{~mL} / \mathrm{h}, 0.33 \mu \mathrm{g}$ curare $/ \mathrm{min}$ ) were proceeded after intubation and catheterization of the tail vene. To detect a decrementing response, series of 8 supramaximal stimuli were given to the nervus tibialis at $3 \mathrm{~Hz}$ with stimulus duration of $0.2 \mathrm{~ms}$ and an interval of 2 minutes. The signal was considered positive when both amplitude and area of the fourth negative peak of the CMAP showed a decrease of at least $10 \%$ when compared to the first response (Losen et al., 2005; Martinez-Martinez et al., 2007). To demonstrate reproducibility, a minimum of three recordings were made with an interval of at least 30 seconds between the repetitive stimulations. During the measurements, skin temperature was kept between $35^{\circ} \mathrm{C}$ and $37^{\circ} \mathrm{C}$ by means of a heating pad.

\section{Statistics}

GraphPad Prism 4 version 4.00 was used to perform statistical analyses. Comparison between normally distributed values was performed using an unpaired t-test or one-way analysis of variance (ANOVA) in which differences between means were subsequently assessed using Tukey's multiple comparison post hoc testing. For notnormally distributed values, a Mann-Whithney test or Kruskall-Wallis test with Tukey's multiple post hoc comparison analysis was performed to assess differences between mean values. Correlations were expressed using Pearson's correlation coefficients and represented by non-linear regression using the $95 \%$ confidence interval. A two-sided probability value $<0.05$ was considered significant. Values are expressed as means \pm standard deviation unless stated otherwise.

\section{Results}

MMF treatment suppresses the development of anti-rat AChR antibodies in EAMG As new effective and safe immunosuppressive drugs are urgently required to improve MG therapy, MMF was tested for its immunosuppressive action in an animal model of MG. In the present study, EAMG rats were treated for 3 or 8 weeks with $M M F$, starting from the day of immunization. Subsequently, anti-rat AChR antibody titers were measured weekly for 8 weeks to determine whether MMF may act immunosuppressive.

Data of both 3 and 8 weeks of MMF treatment are represented together since statistical analyses confirmed similar results in antibody titers during the whole time course. As expected, sham-immunized control rats did not develop anti-rat AChR antibodies. Anti-rat AChR antibody titers of vehicle-treated EAMG rats started to develop 2 weeks after immunization, and continuously increased until the end of treatment $(9.0 \pm 7.0 \mathrm{nmol} / \mathrm{L}$; Fig. $1 \mathrm{~A})$. Interestingly, anti-rat $\mathrm{AChR}$ antibody titers of 
EAMG animals treated for 3 weeks with MMF remained fully suppressed up to 4 weeks after immunization. From week 5 on, anti-rat $A C h R$ antibodies increased slightly, reaching a maximum value of only $0.9 \pm 1.3 \mathrm{nmol} / \mathrm{L}$ at the end of the experimental period. A similar increase occurred also in rats that continued MMF treatment during the entire experimental period. Consequently, the average antibody titer of MMF-treated EAMG animals was however significantly different from vehicle-treated EAMG rats ( $p<0.001$; Fig. 1 B). Although, on the one hand $35 \%$ of MMFtreated rats still possessed antibody titers between 1.0 and $5.4 \mathrm{nmol} / \mathrm{L}$, on the other hand $30 \%$ of MMF-treated EAMG rats did not develop detectable anti-rat AChR antibodies at all (Fig. 1 B); unlike in the untreated EAMG group, where all animals developed detectable anti-AChR titers.

\section{Reduction of anti-rat AChR antibody titers improves clinical outcome in EAMG}

\section{Clinical assessment}

To examine the relation between low or high anti-rat AChR antibody titers and the incidence of MG symptoms, rats were scored weekly for clinical signs. At the time of immunization, body weight was similar for all groups of rats both in the 3 and 8 weeks MMF treatment study (average values of $145 \pm 7$ and $150 \pm 9 \mathrm{~g}$, respectively). Eight weeks later, body weight was equally increased in all animals, reaching average values up to $196 \pm 10$ and $204 \pm 9 \mathrm{~g}$ after 3 and 8 weeks of treatment, respectively (Fig. $2 \mathrm{~A}$ ). In the vehicle-treated EAMG group 6 animals developed mild to severe EAMG signs, 3 of which had to be euthanized in advance due to more than $15 \%$ of weight loss and very severe clinical signs (score III). In comparison, in the MMFtreated EAMG group, only one animal exerted moderate clinical EAMG signs (score II; Fig. 2 B). In conclusion, MMF-induced suppression of anti-rat AChR antibody titers clearly decreased the severity of clinical signs. Importantly, in the MMF-treated animals no adverse side effects such as loss of body weight, fever, diarrhea, dehydration or breathing difficulties were observed.

Neuromuscular transmission and total muscle membrane AChR concentration The clinical efficiency of suppressed anti-rat AChR antibody titers was investigated by quantitative assessment of neuromuscular transmission in the left tibialis anterior muscle during intravenous curare infusion in rats treated for 8 weeks with MMF or vehicle. Curare is known to specifically bind the nicotinic $A C h R$, thereby inhibiting normal functioning of the AChR ion channel. From this point of view, the amount of curare needed to observe decrement of the CMAP was used as a measurement for rat's clinical status.

Fig. 3 A shows that MMF-treated EAMG rats exerted decrementing responses at curare doses in the range of sham-immunized control rats (average values of $8.8 \pm 1.9$ vs $11.6 \pm 1.2 \mu \mathrm{g}$, respectively), while decrement was observed at significantly lower curare doses in vehicle-treated EAMG animals $\{5.8 \pm 2.1 \mu \mathrm{g} ; \mathrm{p}<0.01$ vs MMF- 
EAMG; $p<0.001$ vs Control). Interestingly, an exponential correlation was found between anti-rat AChR antibody titers and the amount of intravenously infused curare in order to observe decrementing responses $\left(y=5.1^{*} \mathrm{e}^{-0.48 x}+5.3 ; p<0.001\right.$; $\mathrm{R}^{2}=0.60$; Fig. $3 \mathrm{~B}$ ). In particular, it seemed that increases in anti-rat $A C h R$ antibody titers above $1 \mathrm{nmol} / \mathrm{L}$ already provoked decrementing responses at about 50\% lower curare levels compared to healthy control animals. Since $88 \%$ of MMF-treated EAMG rats studied under this experimental condition could suppress anti-rat AChR antibody titers even below $1 \mathrm{nmol} / \mathrm{L}$, MMF efficiently improves neuromuscular transmission in EAMG.

To further analyze the effect of MMF immunosuppression on the neuromuscular junction, the AChR concentrations were determined in tibialis anterior muscles of rats treated for 3 weeks with MMF or vehicle. Surprisingly, average membrane AChR concentrations of vehicle-treated and MMF-treated EAMG rats $(9 \pm 3$ and $11 \pm 2$ $\mathrm{fmol} / \mathrm{g}$, respectively) were both significantly decreased by about $45 \%$ when compared to sham-immunized control rats $(18 \pm 3 \mathrm{fmol} / \mathrm{g}$; post hoc $\mathrm{p}<0.001)$. However, several individual AChR concentration values of MMF-treated EAMG animals were in the range of those of sham-immunized controls, and showed thus no evidence of muscle membrane AChR breakdown. Similarly to the aforementioned curare resistance measurements of neuromuscular transmission, a exponential correlation was found between anti-rat AChR antibody titers and total muscle AChR concentration (Fig. $3 \mathrm{C}$ ). Indeed, only a slightly increased anti-rat AChR antibody titer of about 1.0 $\mathrm{nmol} / \mathrm{L}$ was already sufficient to reduce the normal amount of total membrane AChRs by half $\left(y=8.7^{*} e^{-2.96 x}+8.8 ; p<0.001 ; R^{2}=0.68\right)$.

Fluorescent immunohistochemical studies on contralateral tibialis anterior muscles of the same rats treated for 3 weeks with MMF or vehicle confirmed the impact of different anti-rat $A C h R$ antibody titers on the postsynaptic membrane of the neuromuscular junction (Fig. 4). Indeed, compared to controls, triple fluorescent staining of neuromuscular endplates showed a clearly reduced postsynaptic AChR staining in almost all vehicle-treated EAMG rats while the AChR concentration in the neuromuscular junction of MMF-treated animals was variable. More precisely, in MMF-treated EAMG rats with anti-rat AChR antibody titers below about $0.5 \mathrm{nmol} / \mathrm{L}$, almost all neuromuscular junctions stained intensely for AChRs, comparable to those of control rats, while most AChRs seemed to be broken down in rats expressing higher anti-rat $A C h R$ antibody titers. Similar findings were observed for the staining intensity of the receptor associated protein rapsyn. As expected, presynap. tic VAChT staining did not differ between the groups. In conclusion for these biochemical and histochemical findings, it seemed that MMF could prevent breakdown of total muscle membrane AChRs as a result of decreased anti-rat AChR antibody titers. 


\section{Discussion}

Auto-antibodies directed against the a-subunit of the AChR on the postsynaptic membrane of the neuromuscular junction are thought to be the main cause of neuromuscular transmission failure in $M G$, resulting in skeletal muscle fatigue and weakness (De Baets and Stassen, 2002). From this point of view, one of the therapeutic approaches often used for autoimmune MG includes immunosuppressive therapy. Unfortunately, all currently used immunosuppressive drugs carry serious side effects and are not tolerated or do not cause an adequate response in some patients (Ciafaloni, 2005; Garcia-Carrasco et al., 2007; Sieb, 2005). Therefore, the possibility of a new effective, safe and specific immunosuppressive agent to add to the list of MG treatments is very attractive (Ciafaloni, 2005).

The successful use of MMF in MG was first described a decade ago in a girl who had previously failed treatment with azathioprine, prednisone and cyclosporine (Hauser et al., 1998). This case report subsequently prompted investigators to study the effects of MMF in more detail in MG. Adverse events are thought to be absent during treatment, as MMF only interferes with proliferating $B$ - and T-lymphocytes, due to inhibition of inosine monophosphate dehydrogenase type II (IMPDH II), a key enzyme in the de novo pathway of purine synthesis (Allison and Eugui, 2000; Schneider-Gold et al., 2006). Furthermore, as IMPDH II is not involved in the hypoxantine guanine phosphoribosyl transferase salvage pathway of purine synthesis, MMF does not inhibit key enzymes of other cell tissues, which is different from other immunosuppressants that are nowadays used for treatment of MG patients (Patel et al., 2006; Schneider-Gold et al., 2006). For example, azathioprine exert its immunosuppressive effect on both the de novo pathway of purine synthesis and the hypoxantine guanine phosphoribosyl transferase salvage pathway; thereby causing not only inhibition of B- and T- lymphocytes proliferation but also inhibition of purine synthesis in other tissues leading among other side effects to bone marrow suppression (Derijks et al., 2004; Gunnarsdottir and Elfarra, 1999). On the other hand, cyclosporine only inactivates T-helper lymphocytes by blockade of interleukin2 signaling and therefore does not interfere directly with B-lymphocyte proliferation (Hagberg et al., 1988). Since MG is a T-cell dependent and antibody-mediated disease, MMF is not only thought to be a safe, but also a potent immunomodulator for MG (Allison and Eugui, 2000).

In the present study we have demonstrated the beneficial effects of MMF on rats immunized with $t A C h R$, as MMF to our knowledge has not yet been tested in an animal model of MG. MMF did not only act as a potent and safe immunosuppressive drug but also clearly improved neuromuscular transmission in EAMG animals. This experimental disease has previously been shown to be an appropriate model for human MG by different criteria such as cellular and humoral immunological responses, decrementing responses of muscle action potentials in electromyog- 
raphic examinations, as well as transitory improvement by anti-cholinesterase drugs (Lennon et al., 1975).

To test whether MMF could prevent the onset of MG in rats, MMF was administered orally for 3 or 8 weeks, starting from the day of immunization. A dose of 30 $\mathrm{mg} / \mathrm{kg} /$ day was chosen as this dose has already been proven to be efficient in other experimental diseases (Gibson and Hayden, 2007; Tran et al., 2001; ZandmanGoddard and Shoenfeld, 2005). Moreover, MG patients daily receive an oral dose of 1.0-2.0 g, which is in the range of the body weight related dose of MMF used in the present study (Schneider-Gold et al., 2006). The results showed that MMF was able to suppress anti-rat AChR antibody titers to values to $0.9 \pm 1.3 \mathrm{nmol} / \mathrm{L} 8$ weeks after immunization in both experimental regimes. The immunosuppressive properties of MMF in the present study were moreover consistent with findings in MG case reports where antibody titers could already be reduced up to $50 \%$ after one month of MMF treatment (Meriggioli et al., 2003b; Schneider et al., 2001).

Compared to other immunosuppressive agents, the improvement in tolerability and safety profile of MMF is already clearly established in several small studies. Indeed, while most therapeutic immunosuppressive drugs are known to exert severe nephrotoxic and hepatotoxic side effects, clear adverse effects of MMF treatment have been shown to be absent in most MG patients (Garcia-Carrasco et al., 2007). Although we did not rigorously test for side effects of MMF in our experimental model, none of the MMF-treated animals in this study developed overt side effects such as fever, diarrhea, dehydration or breathing difficulties or immunosuppression related infections. Furthermore, MMF seemed to be highly efficient in preventing clinical MG symptoms in $95 \%$ of immunized animals. Single case reports and several small clinical studies concerning MMF treatment in MG confirm the above-mentioned observations as most patients were able to reach pharmacological remission, and improved manual muscle testing and quantitative MG score after several months of treatment (Caponnetto et al., 2001; Chaudhry et al., 2001; Ciafaloni et al., 2001; Hauser et al., 1998; Lim et al., 2007; Meriggioli et al., 2003a; Meriggioli et al., 2003b; Mowzoon et al., 2001; Prakash et al., 2007; Schneider et al., 2001). In contrast, two recently completed large phase 3 prospective, multicenter, placebo-controlled trials showed little or no effect of MMF when it was used as an adjunctive treatment to corticosteroids. Indeed, no improvement was observed in baseline Quantitative Myasthenia Gravis score for disease severity and in the ability to decrease the dose of corticosteroids and cholinesterase inhibitors, as AChR antibody titers decreased equally in both groups by about $50 \%$. However, the obtained results are likely due to a higher than expected response to prednisone alone (Hampton, 2007).

To study the effects of MMF-induced low anti-rat AChR antibody titers on clinical characteristics in more detail, EMG measurements of tibialis anterior muscles were performed during continuous curare infusions. The results indicated a signifi- 
cant improvement in neuromuscular transmission after MMF administration to EAMG rats. Moreover, no significant differences could be observed between MMFtreated EAMG animals and sham-immunized control rats, indicating that the immunosuppressant action of MMF was indeed highly efficient in improving neuromuscular transmission, which is in accordance with the clinical EAMG score discussed earlier. Patient data fully support these findings as improvements in functional status, manual muscle testing and jitter in single fiber EMG were reported after MMF treatment in MG (Chaudhry et al., 2001; Ciafaloni et al., 2001; Hampton, 2007; Meriggioli et al., 2003a; Meriggioli et al., 2003b; Mowzoon et al., 2001; Prakash et al., 2007). Interestingly, the anti-rat AChR antibody titers observed in the present study were moreover exponentially correlated with curare resistance of neuromuscular transmission. Indeed, values above $1.0 \mathrm{nmol} / \mathrm{L}$ of antimrat $A C h R$ antibodies seemed to be responsible for provocation of decrementing responses at about $50 \%$ of the normal curare dose. This indicates that in the present setup only $30 \%$ of all MMFtreated EAMG animals would suffer from as severe neuromuscular deficits as occurring in vehicle-treated EAMG rats, since short-term administration of MMF was able to suppress anti-rat $A C h R$ antibody titers below $1.0 \mathrm{nmol} / \mathrm{L}$ in $70 \%$ of immunized rats (Fig, $1 \mathrm{~B}$ ). These findings suggest the possibility that very low, or even undetectable anti-AChR antibody levels can cause the neuromuscular junction transmission defect in MG patients. At the basis of a high susceptibility of some patients to low levels of auto-antibodies might be genetic differences in the expression levels of postsynaptic proteins. As a case in point, it has been shown that rapsyn, utrophin and s-laminin expression determine disease severity in rats susceptible to EAMG (Hoedemaekers et al., 1998; Losen et al., 2005; Martinez-Martinez et al., 2007).

In relation to neuromuscular transmission, tibialis anterior $A C h R$ concentrations were also determined. The results were rather surprising as $A C h R$ concentrations of both vehicle-treated and MMF-treated EAMG animals were equally decreased by about $45 \%$ when compared to sham-immunized controls, whereas anti-rat AChR antibody titers of MMF-treated EAMG rats were 10 times lower in comparison with vehicle-treated EAMG animals. On the other hand, correlation analysis revealed that the anti-rat $A C h R$ antibody titer is an important determinant in breaking down the AChRs of the muscle. Indeed, a similar relation was observed between antibody titers and muscle AChR concentration when compared to the previously discussed correlation between anti-rat $A C h R$ antibodies and neuromuscular transmission. Severe AChR breakdown up to $50 \%$ of normal values already seemed to occur with an anti-rat $A C h R$ antibody titer of about $1.0 \mathrm{nmol} / \mathrm{L}$. Immunohistochemical analyses of endplate regions fully confirmed these findings. Vehicle-treated EAMG rats seemed to have an overall breakdown of neuromuscular junction AChRs, while endplate AChRs of MMF-treated EAMG animals were not equally destructed. In particular, it seemed that overall endplate AChRs were intact with extremely low antibody titers while AChR breakdown was observed in several neuromuscular junc- 
tions of MMF-treated animals with higher anti-rat AChR antibody titers. It is possible that the membrane AChR loss measured in muscle extracts is in part due to loss of unclustered and more susceptible extrasynaptic AChRs. The electromyoghrapical measurements during challenge with curare are however certainly suggestive of $A C h R$ protection at the neuromuscular junction as a result of MMF treatment.

In summary, these data show that short-term administration of MMF is able to act as a highly immunosuppressive drug in an animal model of MG and consequently improves clinical characteristics by enhancing neuromuscular transmission. Moreover, these data strengthen the case for using MMF as a treatment of human MG, although further large clinical trials are required to determine the exact use of MMF as a sole therapeutic or as an adjunctive treatment to other immunosuppressive drugs.

\section{Acknowledgements}

The authors sincerely thank Aspreva Pharmaceuticals, Palo Alto, United States for their financial support and for providing the MMF.

\section{References}

Allison, A.C., Eugui, E.M., 2000. Mycophenolate mofetil and its mechanisms of action. Immunopharmacology 47, 85-118.

Blaheta, R.A., Leckel, K., Wittig, B., Zenker, D., Oppermann, E., Harder, S., Scholz, M., Weber, S., Schuldes, H., Encke, A., Markus, B.H., 1998. Inhibition of endothelial receptor expression and of T-cell ligand activity by mycophenolate mofetil. Transpl Immunol 6, 251-259.

Caponnetto, C., Rossi, E., Primavera, A., 2001. Mycophenolate mofetil: a new immunosuppressive approach. Successful treatment in a case of myasthenia gravis associated with incomplete lupus erythematosus syndrome and hepatitis $C$ virus infection. Eur Neurol 46, 53-54.

Chaudhry, V., Cormblath, D.R., Griffin, J.W., O'Brien, R., Drachman, D.B., 2001. Mycophenolate mofetil: a safe and promising immunosuppressant in neuromuscular diseases. Neurology 56, 94-96.

Ciafaloni, E., 2005. Mycophenolate mofetil and myasthenia gravis. Lupus 14 Suppl 1, s46-49.

Ciafaloni, E., Massey, J.M., Tucker-Lipscomb, B., Sanders, D.B., 2001. Mycophenolate mofetil for myasthenia gravis: an open-label pilot study. Neurology 56, 97-99.

Cohn, R.G., Mirkovich, A., Dunlap, B., Burton, P., Chiu, S.H., Eugui, E., Caulfield, J.P., 1999. Mycophenolic acid increases apoptosis, lysosomes and lipid droplets in human lymphoid and monocytic cell lines. Transplantation 68, 411-4.18.

De Baets, M., Stassen, M.H., 2002. The role of antibodies in myasthenia gravis. I Neurol Sci 202, 5-11.

Derijks, L.J., Gilissen, L.P., Engels, L.G., Bos, L.P., Bus, P.J., Lohman, J.J., Curvers, W.L., Van Deventer, S.J., Hommes, D.W., Hooymans, P.M., 2004. Pharmacokinetics of 6-mercaptopurine in patients with inflammatory bowel disease: implications for therapy. Ther Drug Monit 26, 311-318.

Drachman, D.B., 1994. Myasthenia gravis. N Engl I Med 330, 1797-1810.

Durez, P., Appelboom, T., Pira, C., Stordeur, P., Vray, B., Goldman, M., 1999. Antiinflammatory properties of mycophenolate mofetil in murine endotoxemia: inhibition of TNF-alpha and upregulation of $1 \mathrm{~L}-10$ release. Int J Immunopharmacol 21, 581-587.

Enk, A.H., Knop, J., 1997. Treatment of pemphigus vuigaris with mycophenolate mofetil. Lancet $350,494$. 
Eugui, E.M., Mirkovich, A., Allison, A.C., 1991. Lymphocyte-selective antiproliferative and immunosuppressive activity of mycophenolic acid and its morpholinoethyl ester (RS-61443) in rodents. Transplant Proc 23, 15-18.

European Mycophenolate Mofetil Cooperative Study Group, 1995. Placebo-controlled study of mycophenolate mofetil combined with cyclosporin and corticosteroids for prevention of acute rejection. Lancet 345, 1321-1325.

Gajdos, P., Chevret, S., Toyka, K., 2006. Intravenous immunoglobulin for myasthenia gravis. Cochrane Database Syst Rev, CD002277.

Garcia-Carrasco, M., Escarcega, R.O., Fuentes-Alexandro, S., Riebeling, C., Cervera, R., 2007. Therapeutic options in autoimmune myasthenia gravis. Autoimmun Rev 6, 373-378.

Gibson, W.T., Hayden, M.R., 2007. Mycophenolate mofetil and atherosclerosis: results of animal and human studies. Ann N Y Acad Sci 1110, 209-221.

Ginzler, E.M., Dooley, M.A., Aranow, C., Kim, M.Y., Buyon, J., Merrill, J.T., Petri, M., Gilkeson, G.S., Wallace, D.J., Weisman, M.H., Appel, G.B., 2005. Mycophenolate mofetil or intravenous cyclophos phamide for lupus nephritis. N Engl J Med 353, 2219-2228.

Goldblum, R, 1993. Therapy of rheumatoid arthritis with mycophenolate mofetil. Clin Exp Rheumatol 11 Suppl 8, \$117-119.

Gronseth, G.S., Barohn, R.1., 2000. Practice parameter: thymectomy for autoimmune myasthenia gravis (an evidence-based review): report of the Quality Standards Subcommittee of the American Academy of Neurology. Neurology 55, 7-15.

Gunnarsdottir, S., Elfarra, A.A., 1999. Glutathione-dependent metabolism of cis-3-(9H-purin-6ylthio)acrylic acid to yield the chemotherapeutic drug 6-mercaptopurine: evidence for two distinct mechanisms in rats. J Pharmacol Exp Ther 290, 950-957.

Hagberg, R.C., Hoyt, E.G., Billingham, M.E., Sibley, R.K., Stames, V.A., Baldwin, J.C., 1988. Comparison of cyclosporin $A$ and $G$ with and without azathioprine regarding immunosuppressive efficacy, toxicity, and pharmacokinetics in Lewis rat5. J Heart Transplant 7, 359-369.

Hampton, T., 2007. Trials assess myasthenia gravis therapies, Jama 298, 29-30.

Hauser, R.A., Malek, A.R., Rosen, R., 1998. Successful treatment of a patient with severe refractory myasthenia gravis using mycophenolate mofetif. Neurology 51, 912-913.

Hoch, W., McConville, J., Helm5, S., Newsom-Davis, J., Melms, A., Vincent, A., 2001. Auto-antibodies to the receptor tyrosine kinase MuSk in patients with myasthenia gravis without acetylcholine receptor antibodies. Nat Med 7, 365-368.

Hoedemaekers, A., Bessereau, J.L., Graus, Y., Guyon, T., Changeux, J.P., Berrih-Aknin, S., van Breda Vriesman, P., De Baets, M.H., 1998. Role of the target organ in determining susceptibility to experimental autoimmune myasthenla gravis. J Neuroimmunol $89,131-141$

Hoedemaekers, A., Graus, Y., van Breda Vriesman, P., de Baets, M., 1997. Age- and sex-related resistance to chronic experimental autoimmune myasthenia gravis (EAMG) in Brown Norway rats. Clin Exp limmunol 107, 189-197.

Larkin, G., Lightman, S., 1999. Mycophenolate mofetil. A useful immunosuppressive in inflammatory eye disease. Ophthalmology 106, 370-374.

Lehmann, H.C., Hartung, H.P., Hetzel, G.R., Stuve, O., Kieseier, B.C., 2006. Plasma exchange in neuroimmunological disorders: part 2. Treatment of neuromuscular disorders. Arch Neurol 63, 1066-1071.

Lennon, V.A., Lindstrom, J.M., Seybold, M.E., 1975. Experimental autoimmune myasthenia: A model of myasthenia gravis in rats and guinea pig5. J Exp Med 141, 1365-1375.

Lim, A.K., Donnan, G., Chambers, B., Jerino, F.L., 2007. Mycophenolate mofetil substitution for cyclosporine-dependent myasthenia gravis and nephrotoxicity. Intern Med J 37, 55-59.

Lindstrom, J.M., Seybold, M.E., Lennon, V.A., Whittingham, S., Duane, D.D., 1976. Antibody to acetylcholine receptor in myasthenia gravis. Prevalence, clinical correlates, and diagnostic value. Neurology 26, 1054-1059. 
Losen, M., Stassen, M.H., Martinez-Martinez, P., Machiels, B.M., Duimel, H., Frederik, P., Veldman, H., Wokke, J.H., Spaans, F., Vincent, A., De Baets, M.H., 2005. Increased expression of rapsyn in muscles prevents acetylcholine receptor loss in experimental autoimmune myasthenia gravis. Brain 128 , $2327-2337$.

Martinez-Martinez, P., Losen, M., Duimel, H., Frederik, P., Spaans, F., Molenaar, P., Vincent, A., De Baets, M.H., 2007. Overexpression of rapsyn in rat muscle increases acetylcholine receptor levels in chronic experimental autoimmune myasthenia gravis. Am I Pathol 170, 644-657.

Meriggioli, M.N., Ciafaloni, E., Al-Hayk, K.A., Rowin, J., Tucker-Lipscomb, B., Massey, J.M, Sanders, D.B., 2003a. Mycophenolate mofetil for myasthenia gravis: an analysis of efficacy, safety, and tolerability. Neurology 61, 1438-1440.

Meriggioli, M.N., Rowin, J., Richman, J.G., Leurgans, S., 2003b. Mycophenolate mofetil for myasthenia gravis: a double-blind, placebo-controlled pilot study. Ann N Y Acad Sci 998, 494-499.

Mowzoon, N., Sussman, A., Bradley, W.G., 2001. Mycophenolate (CellCept) treatment of myasthenia gravis, chronic inflammatory polyneuropathy and inclusion body myositis. J Neurol Sci 185, 119-122.

Neurath, M.F., Wanitschke, R., Peters, M., Krummenauer, F., Meyer zum Buschenfelde, K.H., Schlaak, J.F., 1999. Randomised trial of mycophenolate mofetil versus azathioprine for treatment of chronic active Crohn's disease. Gut 44, 625-628.

Nowack, R., Gobel, U., Klooker, P., Hergesell, O., Andrassy, K., van der Woude, F.J., 1999. Mycophenolate mofetil for maintenance therapy of Wegener's granulomatosis and microscopic polyangitis: a pilot study in 11 patients with renal involvement. J Am Soc Nephrol 10, 1965-1971.

Palace, J., Newsom-Davis, J., Lecky, B., 1998. A randomized double-blind trial of prednisolone alone or with azathioprine in myasthenia gravis. Myasthenia Gravis Study Group. Neurology 50, 1778-1783.

Patel, A.A., Swerlick, R.A., McCall, C.O., 2006. Azathioprine in dermatology: the past, the present, and the future. J Am Acad Dermatol 55, 369-389.

Prakash, K.M., Ratnagopal, P., Puvanendran, K, Lo, Y.L., 2007. Mycophenolate mofetil-as an adjunctive immunosuppressive therapy in refractory myasthenia gravis: The Singapore experlence. J Clin Neurosci $14,278-281$.

Richman, D.P., Agius, M.A., 2003. Treatment of autoimmune myasthenia gravis. Neurology 61, 16521661.

Sanders, D.B., Hart, I.K., Mantegazza, R., Shukla, S.S., Siddiqi, Z.A., De Baets, M.H., Melms, A., Nicolle, M.W., Solomons, N., Richman, D.P., 2008, An international, phase III, randomlzed trial of mycophenolate mofetil in myasthenia gravis. Neurology, in press.

Schneider-Gold, C., Hartung, H.P., Gold, R., 2006. Mycophenolate mofetil and tacrolimus: new therapeutic options in neuroimmunological diseases. Muscle Nerve 34, 284-291.

Schneider, C., Gold, R., Reiners, K., Toyka, K.V., 2001. Mycophenolate mofetil in the therapy of severe myasthenia gravis. Eur Neurol 46, 79-82.

Seybold, M.E., Lambert, E.H., Lennon, V.A., Lindstrom, J.M., 1976. Experimental autoimmune myasthenia: clinical, neurophysiologic, and pharmacologic aspects. Ann N Y Acad Sci 274, 275-282.

Sieb, J.P., 2005. Myasthenia gravis: emerging new therapy options. Curr Opin Pharmacol 5, 303-307.

The Muscle Study Group, 2008. A trial of mycophenolate mofetil with prednisone as initial immunotherapy in myasthenia gravis. Neurology, in press.

Tran, G.T., Carter, N., Hodgkinson, S.J., 2001. Mycophenolate mofetil treatment accelerates recovery from experimental allergic encephalomyelitis. Int Immunopharmacol 1, 1709-1723.

Zandman-Goddard, G., Shoenfeld, Y., 2005. Mycophenolate mofetil in animal models of autoimmune disease. Lupus 14 Suppl 1, \$12-16. 
A

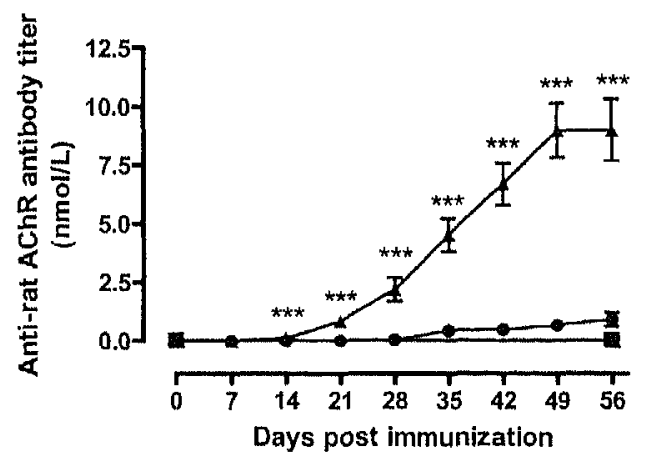

B

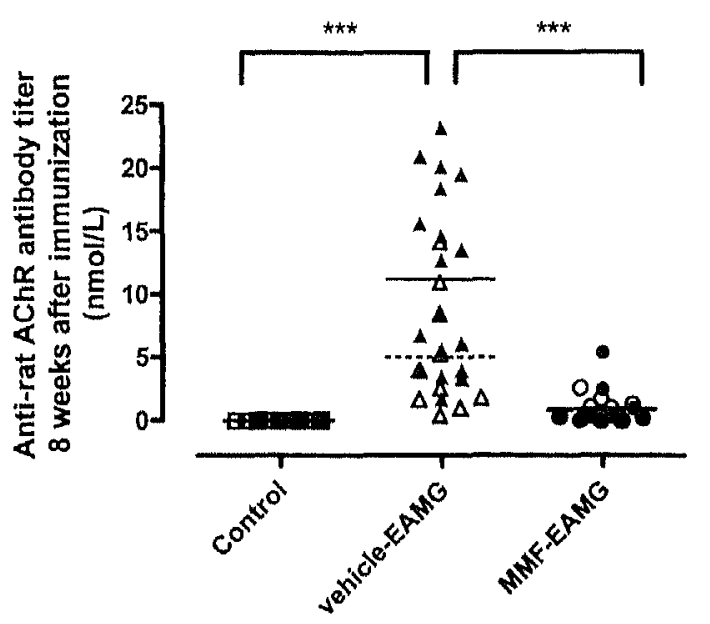

Figure 1. Anti-rat AChR antibody titers in female Lewis rats, immunized at the age of 8 weeks (day 0 ) with $10 \mu \mathrm{g}$ of tAChR in CFA or with CFA only. Upper panel (A) represents the time course of average anti-rat AChR antibody titers of both 3 and 8 weeks MMF treatment regimes together up to 8 weeks after immunization. Control rats $(n=14)$ are represented by closed squares, vehicle-treated EAMG animals $(n=26)$ by clased triangles and MMF-treated EAMG rats $(n=20)$ by closed circles. Data are expressed as mean 1 standard error. Bottom panel (B) corresponds to individual anti-rat AChR antibody titers 8 weeks after immunization. Open symbols correspond to the 3 week MMF treatment and closed symbols to 8 week MMF treatment. Full horizontal lines represent average values in the 3 weeks MMF administration group, while dashed lines represent average values after 8 weeks of MMF treatment.

Note that MMF administration almost completely blocked average anti-rat AChR antibody titers (average endpoint value of $0.9 \pm 1.3 \mathrm{nmol} / \mathrm{L})$ when compared to vehicle-treated EAMG animals $(9.0 \pm 7.0 \mathrm{nmol} / \mathrm{L}$, $p<0.001)$. ANOVA $p$ values in upper panel and Tukey post hoc $p$ values in bottom panel; *** $p<0.001$. 
CHAPTER 1

A

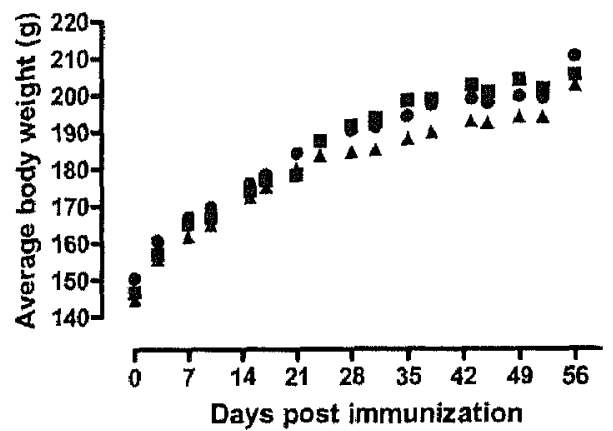

B

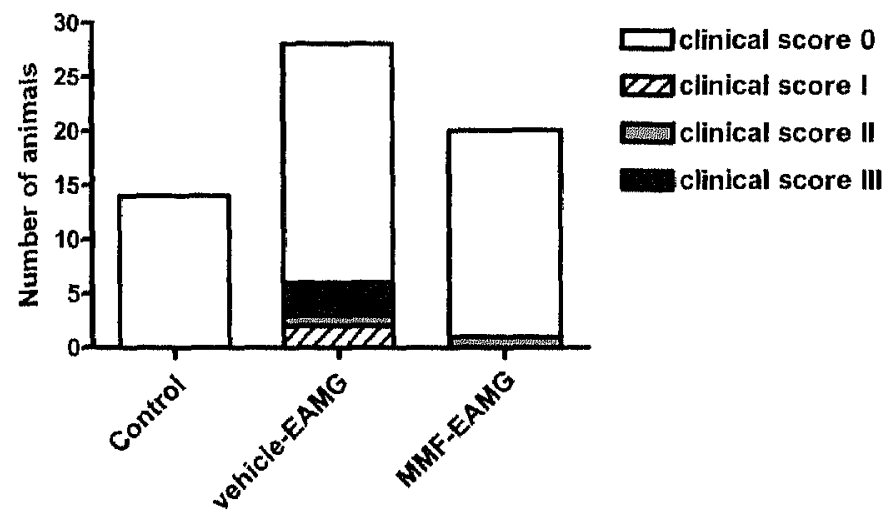

Figure 2. Body weight and clinical myasthenia gravis score. Upper panel (A) represents the time course of body weight of all rats of both the 3 and 8 week treatment regimes together, starting from the day of immunization (day 0) up to 8 weeks after immunization. Control rats $(n=14)$ are represented by closed squares, vehicle-treated EAMG animals $(n=28)$ by closed triangles and MMF-treated EAMG rats $(n=20)$ by closed circles. Data are expressed as mean values. Note that there are no differences in gaining weight between the groups. Bottom panel (B) shows the clinical myasthenia gravis score 8 weeks after immunization of all rats of both MMF treatment regimes together (Control: $n=14$; vehicle-EAMG: $n=28 ; M M F-$ EAMG: $n=20$ ). Open bars represent the number of clinically healthy animals (score 0 ), hatched bars represent the number of mildly sick animals (score 1), grey bars represent the number of moderately ill animals (score II) and solid bars represent the number of severely ill animals (score (II). Note that MMF treatment clearly decreased the appearance of clinical myasthenia gravis signs as only one MMF-treated EAMG animal with score $\|$ could be observed. 
A

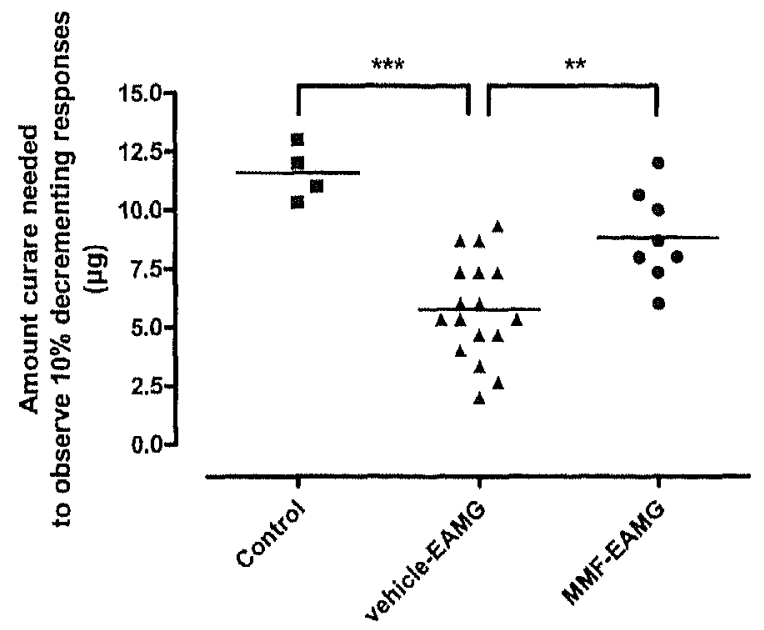

B
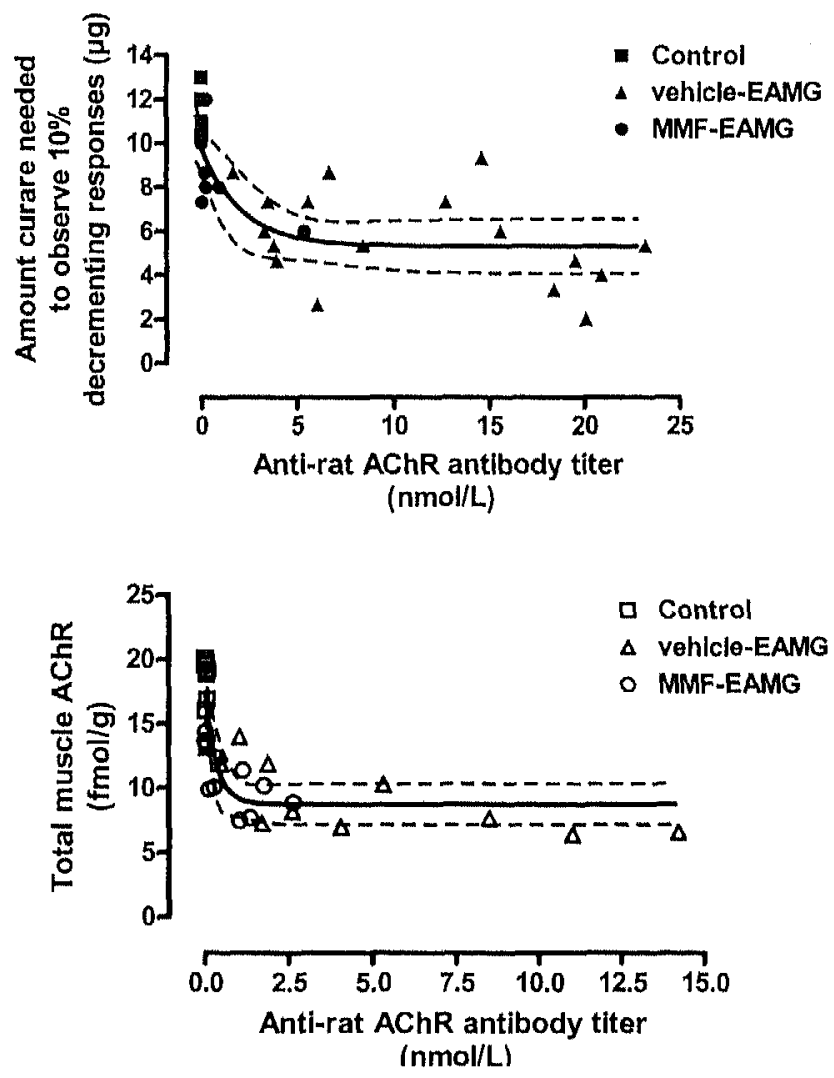
Figure 3. Clinical and biochemical characteristics of the tibialis anterior muscle 8 weeks after immunization in controls, vehicle- and MMF-treated EAMG animals. Upper panel (A) represents the detection of $10 \%$ decrementing responses during intravenous curare infusions $(1 \mathrm{~mL} / \mathrm{h} ; 0.33 \mu \mathrm{g}$ curare $/ \mathrm{min})$, while middle and bottom panel represent the exponential correlation between anti-rat $A C h R$ antibody titers and clinical characteristics (B) or total muscle AChR levels (C), respectively. In panel $A$ and $B$, which represent data of 8 weeks of MMF treatment regime, sham-immunized controls $(n=4)$ are represented by closed squares, vehicle-treated EAMG animals $(n=17)$ by closed triangles and MMF-treated EAMG rats $(n=8)$ by closed circles. In contrast, in panel $C$, which represents data of 3 weeks of MMF treatment regime, sham-immunized controls $(n=10)$ are represented by open squares, vehicle-treated EAMG animals $(n=10)$ by open triangles and MMF-treated EAMG rats $(n=10)$ by open circles. Mean values are indicated by horizontal lines in all panels, while dashed lines represent the $95 \%$ confidence interval in panels $B$ and $C$.

Note the significant decrease in the amount of intravenously infused curare in order to detect decrementing responses in vehicle-treated EAMG animals $(5.8 \pm 2.1 \mu \mathrm{g})$ when compared to controls $(11.6 \pm 1.2$ $\mu \mathrm{g}, 0<0.001$ ). Interestingly, there was a significant increase in the amount of intravenously infused curare when EAMG rats were treated with MMF $(8.8 \pm 1.9 \mu \mathrm{g}, \mathrm{p}<0.01$; panel A). Moreover, a exponential correlation could be observed between the amount of intravenously infused curare and anti-rat $A C h R$ antibody titers $\left(y=5.1 * e^{-0.18 x}+5.3 ; p<0.001 ; R^{2}=0.60 ;\right.$ Fig. 3 B) 8 weeks after immunization. Note that anti-rat $A C h R$ antibody titers above $1.0 \mathrm{nmol} / \mathrm{L}$ already caused decrementing responses at about $50 \%$ of normal curare values. Correlation analysis between total tibialis anterior AChR concentration and anti-rat AChR antibody titers $\left(y=8.7^{*} \mathrm{e}^{2.96 \mathrm{k}}+8.8 ; p<0.001 ; \mathrm{R}^{2}=0.68\right.$; panel $\left.\mathrm{C}\right)$ further revealed that antibody titers above 1 $\mathrm{n} \mathrm{mol} / \mathrm{L}$ provoked a $50 \%$ decrease in total muscle AChR concentration. Tukey post hoc **p<0.01, $* * * p<0.001$. 


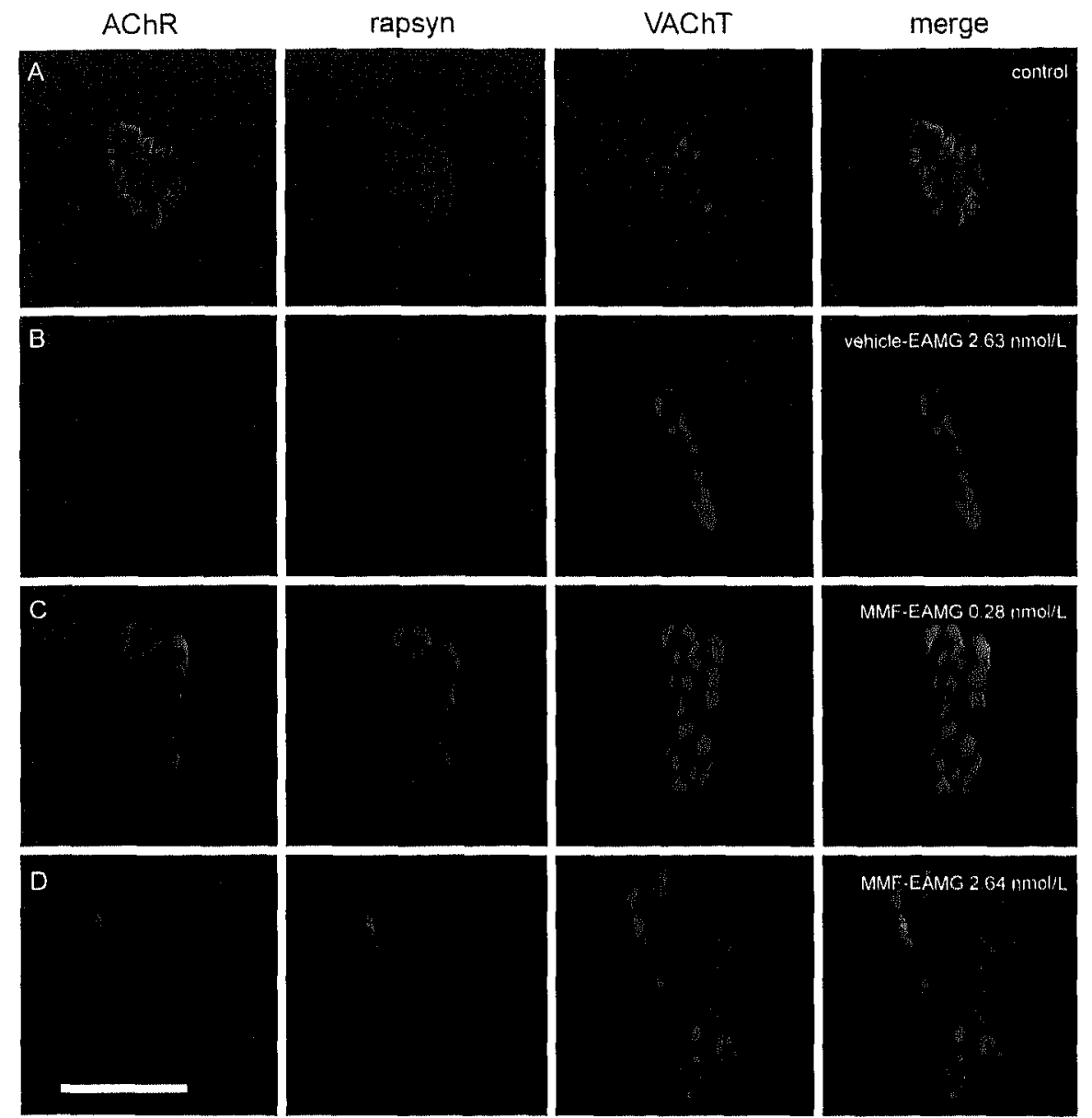

Figure 4. Cryosections of left tibialis anterior muscles, 8 weeks after immunization, triple stained with Alexa 594-conjugated $\alpha$-bungarotoxin (red), mouse anti-rapsyn mAb 1234 (green) and rabbit anti-VAChT (blue) in the neuromuscular junctions of a representative control, vehicle-treated EAMG animal and two EAMG rats treated for 3 weeks with MMF; merge on the right. Panels correspond to $400 \times$ magnification, bar $=25 \mu \mathrm{m}$. Destruction of motor endplates was dependent on the concentration of anti-rat AChR antibody titers. In all control rats, $A C h R$, rapsyn and VAChT were co-localized at the endplate (A). In contrast, all vehicle-treated chronic EAMG rats showed reduced staining of postsynaptic $A C h R$ and ram psyn, but not of presynaptic VAChT (B). In MMF-treated EAMG animals however, normal levels of AChR, rapsyn and VAChT were observed in rats with low antibody titers (C), whereas strongly reduced staining patterns of postsynaptic AChR and rapsyn were observed with high antibody titers (D). 


\section{Chapter 2}

\section{Immunomodulatory effect of the duall altered peptide ligand PTR262 in experimental autoimmune myasthenia gravis in rats}

Marko Phernambucq, Sofie P.M. Janssen, Pilar Martínez-Martínez, Marc H. De Baets and Mario Losen 


\section{CHAPTEB 2}

\section{Abstract}

Myasthenia gravis (MG) is a T cell-mediated and antibody-dependent autoimmune disease. In MG and in its animal model, experimental autoimmune myasthenia gravis (EAMG), antibodies directed against the acetylcholine receptor impair neuromuscular transmission and thereby cause muscle weakness. The $\alpha$-subunit of the acetylcholine receptor contains the immunodominant $T$ cell epitopes. We investigated if and by which mechanism an altered analog of two myasthenogenic peptides, p195-212 and p259-271, representing sequences of the acetylcholine receptor $\alpha$-subunit is able to modulate the autoimmune response in EAMG rats. The production of anti-acetylcholine receptor-specific antibodies was not significantly altered by PTR262 in EAMG Lewis rats. Instead, PTR262 changed the isotype profile of the anti-acetylcholine antibodies; IgG2b autoantibody levels were significantly decreased in PTR262-treated EAMG rats compared to untreated rats, while IgG1 and IgG2a antibody levels were unchanged. Since all these rat IgG antibody isotypes activate the complement system, the decrease of acetylcholine receptor in the muscles and the clinical EAMG symptoms were unaffected by the isotype shift. The results support the hypothesis that PTR262 induces a shift from a Th1 type immune response towards a Th2 type. In conclusion, these results indicate that PTR262 functions as an immune modulator with the capacity to alter the MG specific autoreactive immune response. 


\section{Introduction}

Myasthenia gravis (MG) is an antibody-mediated and $T$ cell-dependent autoimmune disorder, which is characterized by fluctuating muscular weakness. Antibodies directed against the nicotinic acetylcholine receptor (AChR), which is located at the postsynaptic membrane of the neuromuscular junction are the cause of the clinical symptoms in the majority of MG patients (AChR-MG). The antibody attack results in a decreased amount of available AChRs necessary for the nerve-muscle signal transmission (Drachman, 1994; Lindstrom, 1985; Lindstrom et al., 1988). This form of $M G$ can also be induced in experimental animals by immunization with AChR from Torpedo californica (experimental autoimmune MG, EAMG). In MG patients without antibodies to the AChR, antibodies against the muscle specific tyrosine kinase are frequently underlying the disease (Hoch et al., 2001) with distinct clinical features (Lavrnic et al., 2005).

The $\alpha$-subunit of the AChR contains the dominant $T$ cell receptor epitope in patients with AChR-MG (Brocke et al., 1988). Two peptides representing sequences of the human AChR $\alpha$-subunit, namely p195-212 and p257-271, were also found to form the immunodominant epitopes in mice. Immunization with these peptides resulted in the generation of antibodies directed against the AChR, an increase in EAMG-related clinical symptoms and decrement of the compound muscle action potential (Brocke et al., 1990; Kirshner et al., 1994). Similarly, in rats, EAMG can be induced by immunizing with either the $t A C h R$ or with a synthetic peptide corresponding to the rat AChR- $\alpha 1$ 97-116 amino acid sequence (Baggi et al., 2004), which contains the immunodominant epitopes in Lewis rats (Fujii and Lindstrom, 1988).

To inhibit $T$ cell responses against the immunodominant epitopes, a tandemly arranged analog of the previously described myasthogenic peptides was constructed, designated as PTR262 (Katz-Levy et al., 1997). Substitution of two amino acids, namely Lys-262-Ala-207 is responsible for the inhibitory action of this $T$ cell receptor ligand (Table 1). In C57/BL/6 mice, immunized with Torpedo AChR (tAChR), treatment with PTR262 was able to diminish clinical manifestations of EAMG as assessed by clinical scoring, gripforce strength and electromyographic measurements (Aruna et al., 2006a; Paas-Rozner et al., 2000). Moreover, the anti-AChR IgG titers were reduced in PTR262-treated mice.

The exact mechanism by which PTR262 exerts its function is not completely understood. PTR262 probably acts by stimulating regulatory CD4+CD25+ regulatory T cells, which have the ability to suppress MG-associated immune responses. Foxp3, TGF- $\beta$ and CTLA- 4 were upregulated at the surface membrane of CD $4+C D 25+T$ cells in SJL mice treated with PTR262 (Aruna et al., 2005; Aruna et al., 2006b; Paas. Rozner et al., 2003). Upregulation of these membrane proteins is likely due to a PTR262-induced stimulation of phosphorylated extracellular-regulated kinase 1 and 2 (Ben-David et al., 2007), Moreover, CD4+CD25+ $T$ cell activation resulted in a shift 
of T helper (Th) 1 -type cytokines profile (IFN- $\gamma$, IL 2 and IL-12) towards a more Th2type cytokine profile (IL-4 and IL-10) in EAMG mice treated with PTR262 (PaasRozner et al., 2000; Paas-Rozner et al., 2001; Zhang et al., 2001).

In mice, the switch in immune response of Th1 towards Th2 is beneficial, due to the different complement binding properties of murine IgG isotypes. Murine Th1 cells induce B cells to produce complement fixing antibodies of the IgG2 isotypes, while Th2 cells induce the production of $\operatorname{lgG} 1$ antibodies that do not activate complement (Table 2) (Wang et al., 2004). As a result of this shift less complement-fixing antibodies will bind to the AChR receptor and the damage to the neuromuscular junction is reduced. Conversely, in EAMG rats both Th1 and Th2 cells can stimulate $B$ cells to produce complement fixing antibodies (Saoudi et al., 1999b) as shown in Table 2. Therefore, skewing of the immune response does not affect EAMG development in rats: IL-12 treatment or blocking of IFN- $\gamma$ increase IgG1 levels and decrease IgG2b without preventing disease (Saoudi et al., 1999a).

In AChR-MG patients most abundant antibodies are of the $\lg G 1$ and the $\lg G 3$ isotype (Rodgaard et al., 1987). Both can activate complement. The role of Th1 and Th2 balance on the production of these antibody isotypes in human MG is not clearly established. There is evidence suggesting that the antibody response in MG is Th1 as well as Th2 dependent (Balasa and Sarvetnick, 2000; Link et al., 1994b), while other studies reported that MG in humans is mainly Th1 dependent (Moiola et al., 1994; Tackenberg et al., 2007; Wang et al., 1997).

A PTR262-induced activation of Th2 cells might increase antibodies of the human IgG4 isotype. The non-complement fixing IgG4 antibody is anti-inflammatory, non-pathogenic and can even protect the AChR against IgG1 antibodies with the same epitope specificity (Losen et al., 2008a; van der Neut Kolfschoten et al., 2007). If the therapeutic effect of PTR262 is based on a shift of a Th1 type towards a more Th2 type immune response and not on a suppression of the immune response, this consequently has implications for the effectiveness of PTR262 in rats and in man (Saoudi et al., 1999a). Therefore, we addressed the question if PTR262 could also protect against EAMG in rats.

\section{Materials and Methods}

\section{Rats}

Seven-weeks-old female Lewis rats were obtained from the Department of Experimental Animal Services, University of Maastricht, The Netherlands, with permission of the Committee on Animal Welfare, according to Dutch governmental rules 
For immunization and electromyography measurements, rats were anesthetized with $3 \%$ isoflurane in air. Euthanasia was performed by $\mathrm{CO}_{2}$ /air inhalation and subsequent cervical dislocation.

\section{Induction of chronic EAMG}

EAMG was induced by injecting seven-weeks-old rats at the base of the tail with 40 $\mu \mathrm{g}$ of tAChR dissolved in $0.1 \mathrm{ml}$ phosphate buffered saline (PBS) emulsified in $0.1 \mathrm{~mL}$ Freunds' adjuvant with $1 \mathrm{mg} / \mathrm{ml}$ Mycobacterium tuberculosis (Difco Laboratories, Detroit, MI). Control rats were injected with a similar volume of PBS and complete Freunds' adjuvant, without tAChR. Blood samples were taken weekly from the vena saphena.

\section{Administration of the dual altered peptide}

The experimental design consited of three groups: Control rats $(n=6)$ did not receive PTR262. Two groups of rats ( $n=25$ each) were immunized with $t A C h R$ at seven weeks of age (EAMG groups). One EAMG group was treated twice a week with 0.5 $\mathrm{mg}$ PTR262 dissolved in $200 \mu \mathrm{l}$ vehicle solution (water with $2.5 \mathrm{mmol} / \mathrm{l}$ acetic acid and $5 \%$ mannitol) during 8 weeks starting from the day of immunization (PTR EAMG). The other EAMG group was only treated with $200 \mu$ vehicle solution twice a week during 8 weeks (vehicle EAMG).

Prior to injection, PTR262 was dissolved in vehicle solution for 12 hours at $37^{\circ} \mathrm{C}$. Vehicle and PTR262 were injected subcutaneously in the neck. Eight weeks after immunization, all rats were euthanized.

\section{Clinical score}

The severity of clinical signs was scored weekly by measuring muscular weakness. The rats' muscular strength was assessed by their ability to grasp and lift repeatedly a 300-gram rack from the table while suspended manually by the base of the tail for 30 seconds (Martinez-Martinez et al., 2007). Clinical scoring was based on the presence of tremor, hunched posture, muscle strength, body weight and signs of fatigue. Body weight was measured two times a week. Signs of EAMG were graded as follows: 0 , no clinical signs observed; 1 , no signs observed before testing; 2 , clinical signs present before testing, i.e. hunched posture, weak grip, 3 ; severe muscle weakness, moribund, malnutrition, dehydratation or more than $10 \%$ loss of body weight. Rats were euthanized before the end of the experiment if more than $15 \%$ of weight loss was observed. 


\section{Detection of serum anti rat-AChR and antj-tAChR antibodies}

Antibodies against rat AChR were detected as described before (Lindstrom et al., 1976c) with minor modifications (Martinez-Martinez et al., 2007). Briefly, $150 \mu \mathrm{l}$ extract of denervated rat muscle $(\sim 5 \mathrm{nmol} / \mathrm{l})$ was labeled with a two fold excess of ${ }^{125} \mathrm{I}-\alpha-\mathrm{BT}$ (5.55 TBq/mmol; GE Health Care, Amersham, UK) and incubated with $5 \mu \mathrm{l}$ of rat serum at $4^{\circ} \mathrm{C}$ overnight. Antibodies against tAChR were detected by labeling $0.05 \mu \mathrm{g}$ tAChR with ${ }^{125} \mid-\alpha-B T$. These labeled tAChRs were mixed with $5 \mu$ l serum diluted 1:200 in PBS and with $2.5 \mu$ normal rat serum as a co-precipitant.

The formed immune-complexes were then precipitated using $100 \mu$ l of secondary goat anti-rat antibody serum and centrifugation at $14500 \times \mathrm{g}$ for 5 minutes. Pellets were washed three times in PBS with $0.5 \%$ Triton X-100. Finally, radioactivity was measured in a $\gamma$-counter ( 1480 Wizard 3", PerkinElmer, USA). Titers were expressed in $\mathrm{nmol} / \mathrm{L}$ toxin binding sites.

\section{Measurement of total muscle AChR concentration}

Total muscle AChR was measured with a radioimmunoassay as described before (Lindstrom et al., 1976c) with minor madifications (Losen et al., 2005). Briefly, tibialis anterior muscles were homogenized with an Ultra-Turrax ( 3 times for 30 seconds) at $4^{\circ} \mathrm{C}$ in $10 \mathrm{ml}$ of extraction buffer (PBS, $10 \mathrm{mmol} / 1 \mathrm{NaN}_{3}, 10 \mathrm{mmol} / \mathrm{l}$ iodoacetamide and $1 \mathrm{mmol} / \mathrm{l}$ phenylmethyl sulfonyl fluoride). The homogenate was centrifuged at $22.100 \mathrm{~g}$ for 30 minutes and the resulting pellet was resuspended in $2.5 \mathrm{ml}$ extraction buffer supplemented with $2 \%$ Triton $\mathrm{X}-100$. AChR was extracted from the membrane on a reciprocal shaker during 1 hour at $4^{\circ} \mathrm{C}$, followed by centrifugation at $22100 \mathrm{~g}$ for 30 minutes at $4^{\circ} \mathrm{C}$. AChR concentrations were then measured in the supernatant using an excess of ${ }^{125}$ - $\alpha$-bungarotoxin $(74 \mathrm{TBq} / \mathrm{mmol}, \mathrm{GE}$ healthcare, Amersham Place, UK). Total muscle membrane AChR concentration was calculated per gram of fresh muscle and thus expressed in $\mathrm{fmol} / \mathrm{g}$.

\section{ELISA for measurement of serum anti-AChR antibody isotypes}

The isotype distribution of anti-AChR antibodies was determined by ELISA using anti-rat Ig isotype specific antibodies, as previously described (Saoudi et al., 1999a). High binding microtiter plates (Falcon 3012, Becton Dickenson Labware, Oxnard, CA) were coated overnight at $4^{\circ} \mathrm{C}$ with $\mathrm{AAChR}$ in PBS $(50 \mu \mathrm{l}, 5 \mu \mathrm{g} / \mathrm{ml})$ followed by washing 3 times with $100 \mu \mathrm{l}$ ELISA buffer (PBS with $0.5 \%$ Tween 20) and blocking for 15 minutes with $0.5 \%$ bovine serum albumin dissolved in ELISA buffer. Rat sera diluted in ELISA buffer were added and anti-tAChR antibodies were allowed to bind for 1 hour at room temperature. Each serum was tested in duplicate and assessed in 4 dilutions $(1: 317,1: 1000,1: 3170$ and $1: 10000)$. Fifty $\mu$ of the monoclonal anti-AChR antibodies mAb 35 (IgG1), mAb 155 ([gG2a) and mAb 22 (IgG2b) was used a concen- 
tration of $2 \mu \mathrm{g} / \mathrm{ml}$ to prepare standard curves, using the same dilutions as for the sera (Loutrari et al., 1992; Osborn et al., 1992). After extensive washing, bound $\lg G 1$, IgG2a and IgG2b anti-tAChR antibodies were detected with mouse anti-rat $\psi 1$, $\mathrm{2a}$ or $\mathrm{y} 2 \mathrm{~b}$ monoclonal antibodies, which were a kind gift of $\mathrm{H}$. Bazin of the University of Louvain. Subsequently, the plates were incubated with peroxidase-labeled goat anti-mouse (Dako, Glostrup, Denmark) diluted 1:2000 in ELISA buffer. Plates were washed again and incubated for $1 \mathrm{~h}$ with $100 \mu \mathrm{ABC}$ staining solution (Vector Laboratories, UK) at $37^{\circ} \mathrm{C}$ followed by 5 times washing. Finally, the plates were incubated with $100 \mu \mathrm{l}$ of the developing substrate 3,3-5,5-tetramethylbenzidine (Fluka Chemie, Buchs, Switzerland). The staining reaction was then stopped by addition of $50 \mu$ of $1 \mathrm{M} \mathrm{H}_{2} \mathrm{SO}_{4}$, and the absorbance was measured at $450 \mathrm{~nm}$ with a microplate ELISA reader. Optical densities of samples and standards were plotted versus logarithm of the dilution factor and fitted using a sigmoidal four-parameter fit using GraphPad Prism 4.0 software. EC50 (50\% effective concentration) values were calculated and used for quantification of anti-AChR isotype specific titers.

\section{Statistics}

Statistical analyses were performed with Graphpad Prism 4 version 4.0. The unpaired student's t-test was used to compare differences between EAMG rats. When all 3 groups were compared, a one-way analysis of variance was used followed by a Bonferroni post-hoc analysis. A two-sided probability value $<0.05$ was considered significant. Values are expressed as mean \pm standard deviation (SD) unless stated otherwise.

\section{Results}

\section{PTR262 treatment does not prevent EAMG}

The dual altered peptide PTR262 was tested in the EAMG rat model for its ability to prevent myasthenic symptoms. Therefore, we immunized a total of 50 animals with tAChR in complete Freunds' adjuvant and subsequently treated 25 rats with PTR262, while the other animals received injections of vehicle solution. The body weight was measured weekly and rats were scored for their clinical manifestations (Table 3). Five animals in the PTR262-treated group and four animals in the vehicletreated group suffered from a severe weight loss. At the end of the treatment period, the average clinical score in PTR EAMG rats $(1.28 \pm 0.97)$ was not significantly different from the clinical score in vehicle EAMG animals $(1.24 \pm 1.28, p=0.89)$. 
CHAPTER 2

\section{PTR262 does not decrease the anti-AChR antibody response}

Since clinical scores and weight loss do not necessarily correlate to autoantibody titers in EAMG and only $1 \%$ of antibodies against tAChR cross-react with rat AChR, we analyzed both the anti-tAChR and anti-rat AChR antibody production in all immunized animals. Antibody titers were measured weekly, during 8 weeks by a radioimmunoassay, starting from the day of immunization. Antibodies directed against the $T A C h R$ were already detected in PTR EAMG and vehicle EAMG rats after 1 week (Figure 1A), while antibodies against rat AChR were only detected after 3 weeks (Figure 1B). Antibody levels were rising during the whole time course, except for antibodies directed against rat AChR in a few vehicle-treated animals, which declined slightly in the last two weeks of the experiment (Figure 1C).

At the end of the experiment $t A C h R$ antibody levels in vehicle EAMG rats (2579 $\pm 1197 \mathrm{nmol} / \mathrm{l})$ were comparable to those of PTR EAMG rats $(2529 \pm 1655 \mathrm{nmol} / \mathrm{l}, \mathrm{p}$ $=0.92$; Figure $1 \mathrm{~B}$ ). There was no significant difference between antibodies directed against rat AChR in PTR262-treated EAMG rats $(24.7 \pm 22.9 \mathrm{nmol} / \mathrm{I})$ and in vehicletreated EAMG rats $(23.2 \pm 22.1 \mathrm{nmol} / \mathrm{l} ; \mathrm{p}=0.81$, Figure $1 \mathrm{D})$.

\section{PTR262 treatment does not affect AChR loss in EAMG rats}

The quantification of AChR-loss of the muscle is a sensitive measure for $M G$, since it precedes clinical symptoms. Total muscle membrane AChR concentration was measured at the end of the experimental period in the right tibialis anterior as a measure of the damage of the autoantibodies to the neuromuscular junction (Figure 2). The average values of the PTR262-treated rats $(12.0 \pm 4.3 \mathrm{fmol} / \mathrm{g})$ and vehicle-treated EAMG rats $(11.3 \pm 3.1 \mathrm{fmol} / \mathrm{g})$ were significantly decreased compared to control $(22.3 \pm 8.9 \mathrm{fmol} / \mathrm{g}, \mathrm{p}<0.001)$. There was however no significant difference between PTR EAMG and vehicle EAMG animals $(p=0.52)$.

\section{Administration of PTR262 induces a Th2 type lgG isotype profile}

To further investigate the effect of PTR262 on the antibody response in EAMG, we analyzed if PTR262 was able to shift the immune response from a Th1 type of reaction towards a more Th2 type. To this end, we analyzed the concentrations of IgG1, IgG2a and lgG2b directed to the Torpedo AChR in both vehicle-treated and PTR262treated EAMG rats in serum taken eight weeks after immunization. The concentration of IgG2b was significantly lower in PTR-treated EAMG rats compared to vehicle treated EAMG rats $(p=0.038)$. The concentrations of IgG1 and IgG2a were not significantly different in both groups, although there was a trend towards an increase of IgG1 antibodies and a decrease in the concentration of IgG2a antibodies in the PTR262-treated group compared to the vehicle-treated EAMG group. Rat IgG1 is associated with a Th2 type immune response, lgG2b is typical for a Th1 type im- 
mune response (Gracie and Bradley, 1996). These results indicate that there is a polarization towards a Th2 type immune response resulting in a shift of anti-AChR antibody isotype profile in PTR262-treated rats without an effect on the total antiAChR antibody response.

\section{Discussion}

MG and EAMG are both T cell-regulated and antibody- and complement-mediated autoimmune diseases. The T cell receptor ligand PTR262 is a promising immunomodulatory drug, which might be able to suppress the pathogenic immune response in MG. In this study we investigated if PTR262 was able to affect the immune response in EAMG in rats immunized with TAChR. The results showed that PTR262 did not prevent EAMG induction; the rats developed clinical symptoms, weight loss, anti-rat-AChR antibodies and the concentration of AChR in the muscles was decreased. In all of these aspects PTR262-treated rats were not significantly different from untreated rats. However, PTR262 induced a shift of the AChR-specific antibody isotype profile towards a typical Th2 immune response, thus a reduction of rat IgG2b while IgG1 and IgG2a antibody levels were not significantly changed.

Studies in Lewis rats showed that in EAMG both AChR-reactive Th1 and Th2 cells are involved. Polarization of the immune response has no influence on the development of EAMG in rats (Saoudi et al., 1999a; Saoudi et al., 1999b; Saoudi et al., 2000; Saoudi et al., 1993). To understand the difference it is important to mention that mice and rats are different with respect to their antibody effector functions activated by each of the Th-type responses. Stimulating lymph node cells from rats with tAChR stimulates the production of $\operatorname{lgG} 1$ as well as $\lg G 2 b$, which are both complement binding antibodies, suggesting a role for a Th1 as well as a Th2 response in the pathogenesis of EAMG (Saoudi et al., 1993). Similar to the aforementioned studies in mice, we also observed a polarization of the immune response towards a Th2 antibody profile in PTR262 treated rats with EAMG. After 8 weeks, PTR262 significantly suppressed the antibody titers of the IgG2b isotype but not those of the IgG1 or IgG2a isotype. We cannot exclude the possibility that the immunomodulatory effect of PTR262 in the rat is unspecific, since synthetic peptides can suppress immune responses by competing for the MHC class II molecules, since this can also reduce anti-AChR IgG2b levels specifically (Wauben et al., 1996). It is quite likely, that the unchanged total anti-AChR antibody levels in PTR262-treated animals are the result of a genetically restricted peptide specificity of T-cells in Lewis rats (Fujii and Lindstrom, 1988). We may conclude that, like in mice PTR262 also skews the immune response in rats towards the Th2-type, however, this has no positive effect on the clinical outcome of PTR262 treatment, because in rats Th1 as 
well as Th2-type antibodies are pathogenic and the $\lg G 2 \mathrm{~b}$ has only a minor contribution to the overall titer.

The use of PTR262 as a therapeutic agent in humans will depend on its efficiency in treating already established MG. Until this moment, most conventional therapies in $M G$ are directed on inhibiting the immune response in a non-specific way. Immunosuppressive drugs like azathioprin, cyclosporine and mycophenolate mofetyl exert their effect by inhibiting the proliferation of lymphocytes, which can result in serious side effects (Juel and Massey, 2007). Thus, new therapies for MG should not aim at the impairment of the function of the immune system in general, but modulate the antigen-specific immune response itself. Therefore, the use of altered peptides is a promising strategy for the specific treatment of MG.

What are the consequences of these results for the potential use of PTR262 in human MG patients? CD4+ cells from MG patients can secrete Th1 as well as Th2 type cytokines (Link et al., 1994a; Yi et al., 1994). Furthermore, IgG1 and IgG3 antibodies against the $A C h R$ are the predominant subclasses in MG (Rodgaard et al., 1987). These results suggest that in humans complement fixing-antibodies can be generated with Th1 as well as Th2 mediated T cell help. At this point it is therefore not completely predictable how dual altered peptides that divert the immune response towards a Th2 profile would affect the isotype profile in MG patients. However, the prospect of inducing the production of anti-inflammatory IgG4 anti-AChR antibodies instead of pathogenic IgG1 and IgG3 by a specific immunotherapy seems promising. Although extremely low titers (below $1 \mathrm{nM}$ ) of pathogenic anti-AChR antibodies can be sufficient to damage the neuromuscular junction in rats (Janssen et al., 2008a) and in MG patients (Leite et al., 2008), it has been observed that a titer reduction of $50 \%$ is generally sufficient to induce remission in individual MG patients (Seybold, 1987). Moreover, even at higher IgG1 titers, the neuromuscular junction can be protected if competing non-pathogenic antibodies (eg. $\operatorname{lgG} 4$ ) or antibody fragments are present in the serum (Papanastasiou et al., 2000; Toyka et al., 1980; van der Neut Kolfschoten et al., 2007).

Previous data in multiple sclerosis (MS) showed that peptide analogs of $T$ cell epitopes can reverse already established autoimmune disease. Glatiramer acetate (GA, also called Copaxone) is a synthetic polypeptide composed of four amino acids that are found in myelin basic protein (Teitelbaum et al., 1971). GA is immunologically cross-reactive of myelin basic protein and was shown to be effective in treating autoimmune encephalomyelitis (EAE) in mice (Teitelbaum et al., 1997) and in MS. Although the mechanism of action of GA is not fully understood, reports indicate that GA treatment induces a Th1 to Th2 shift in GA-specific T cells (Miller et al., 1998; Neuhaus et al., 2000). Moreover, it was shown that GA acts against the immunodominant epitope of myelin basic protein by T-cell receptor antagonism. In a long-term treatment-study with GA it was shown that initially GA-reactive IgG1. subclass antibodies predominated, but after 9 months IgG1 decreased while IgG4 
antibodies increased and continued to be the dominating subclass (Basile et al., 2006). Since it becomes increasingly clear that autoantibodies to MBP might play a pathogenic role in MS (Fraussen et al., 2009; Fredrikson et al., 1992), the production of $G A$ and MBP reactive $\operatorname{lgG} 4$ antibodies might contribute to the therapeutic effect of $G A$.

Our results support the hypothesis that PTR262 acts by inducing a Th2-type antibody-isotype profile in the rat. The induction of a polarized Th2 antibody response in MG patients might lead to a beneficial outcome, because Th2 responses in humans can potentially lead to the production of anti-inflammatory IgG4 anti-AChR antibodies. If PTR262 or other altered peptides are similarly able to favor the production of non-pathogenic IgG4 antibodies in MG patients this might become an effective antigen-specific treatment strategy in humans.

\section{Acknowledgements}

We thank Professor Hervé Bazin of the University of Louvain, Belgium, for the kind gift of mouse anti-rat IgG isotype specific monoclonal antibodies. This study was financially supported by Debiovision.

\section{References}

Aruna, B.V., Ben-David, H., Sela, M., Mozes, E., 2006a. A dual altered peptide ligand down-regulates myasthenogenic $T$ cell responses and reverses experimental autoimmune myasthenia gravis via upregulation of Fas-FasL-mediated apoptosis. Immunology 118, 413-424.

Aruna, B.V., Sela, M., Mozes, E., 2005. Suppression of myasthenogenic responses of a $T$ cell line by a dual altered peptide ligand by induction of CD4+CD25+ regulatory cells. Proc Natl Acad Sci U S A 102, 10285-10290.

Aruna, B.V., Sela, M., Mozes, E., 2006b. Down-regulation of T cell responses to AChR and reversal of EAMG manifestations in mice by a dual altered peptide ligand via induction of CDA+ CD25+ regulatory cells. J Neuroimmunol 177, 63-75.

Avery, D.T., Bryant, V.L., Ma, C.S., de Waal Malefyt, R., Tangye, S.G., 2008. IL-21-induced isotype switch. ing to IgG and IgA by human naive $B$ cells is differentially regulated by IL-4. J Immunol 181, 1767 . 1779.

Baggi, F., Annoni, A., Ubiali, F., Milani, M., Longhi, R., Scaioli, W., Cornelio, F., Mantegazza, R., Antozzi, C., 2004. Breakdown of tolerance to a self-peptide of acetylcholine receptor alpha-subunit induces experimental myasthenia gravis in rats. J I mmunol 172, 2697-2703.

Balasa, B., Sarvetnick, N., 2000. Is pathogenic humoral autoinmunity a Th1 response? Lessons from (for) myasthenia gravis. Immunol Today 21, 19-23.

Basile, E., Gibbs, E., Aziz, T., Oger, J., 200G. During 3 years treatment of primary progressive multiple sclerosis with glatiramer acetate, specific antibodies switch from IgG1 to IgG4.J Neuroimmunol 177, $161-166$.

Bazin, H., 1990. Rat Immunoglobulins. In: Bazin, H. (Ed.), Rat Hybridomas and Rat Monoclonal Antibodies, CRC press, Boca Raton, pp. 5-42. 
Ben-David, H., Venkata Aruna, B., Sela, M., Mozes, E., 2007. A Dual Altered Peptide Ligand Inhibits Myasthenia Gravis Associated Responses by Inducing Phosphorylated Extracellular-regulated Kinase 1,2 that Upregulates CD4(+)CD25(+)Foxp3(+) Cells. Scand J Immunol 65, 567-576.

Brocke, S., Brautbar, C., Steinman, L., Abramsky, O., Rothbard, J., Neumann, D., Fuchs, S., Mozes, E., 1988. In vitro proliferative responses and antibody titers specific to human acetylcholine receptor synthetic peptides in patients with myasthenia gravis and relation to HLA class I| genes. J Clin Invest 82, 1894-1900.

Brocke, S., Dayan, M., Rothbard, J., Fuchs, S., Mozes, E., 1990. The autoimmune response of different mouse strains to T-cell epitopes of the human acetylcholine receptor alpha subunit. Immunology 69 , 495-500.

de Boer, B.A., Kruize, Y.C., Rotmans, P.J., Yazdanbakhsh, M., 1997. Interleukin-12 suppresses immunoglobulin $E$ production but enhances immunoglobulin $G 4$ production by human peripheral blood mononuclear cells. Infect Immun 65, 1122-1125.

Drachman, D.B., 1994. Myasthenia gravis. N Engl I Med 330, 1797-1810.

Fraussen, J., Vrolix, K., Martinez-Martinez, P., Losen, M., De Baets, M.H., Stinissen, P., Somers, V., 2009. B cell characterization and reactivity analysis in multiple sclerosis. Autoimmun Rev 8, 654-658.

Fredrikson, S., Michelsberg, J., Hillert, J., Wang, Z., Sun, J.B., Olerup, O., Olsson, T., Link, H., 1992. Conjugal multiple sclerasis: immunogenetic characterization and analysis of $\mathrm{T}$ - and $\mathrm{B}$-cell reactivity to myelin proteins. Neurology 42, 577-582.

Fujii, Y., Lindstrom, J., 1988. T-cell clones specific to acetylcholine receptor, its subunits, and peptides. Ann N Y Acad Sci 540, 357-359.

Gracie, J.A., Bradley, J.A., 1996. Interleukin-12 induces interferon-gamma-dependent switching of IgG alloantibody subclass. Eur J Immunol 26, 1217-1221.

Hoch, W., McConville, J., Helms, S., Newsom-Davis, J., Melms, A., Vincent, A., 2001. Auto-antibodies to the receptor tyrosine kinase MUSK in patients with myasthenia gravis without acetylcholine receptor antibodies. Nat Med 7, 365-368.

Janssen, S.P., Phernambucq, M., Martinez-Martinez, P., De Baets, M.H., Losen, M., 2008. Immunosuppression of experimental autoimmune myasthenia gravis by mycophenolate mofetil. I Neuroimmunol.

Juel, V.C., Massey, J.M., 2007. Myasthenia gravis, Orphanet J Rare Dis 2, 44.

Katz-Levy, Y., Paas-Rozner, M., Kirshner, S., Dayan, M., Zisman, E., Fridkin, M., Wirguin, 1., Sela, M., Mozes, E., 1997. A peptide composed of tandem analogs of two myasthenogenic $T$ cell epitopes interferes with specific autoimmune responses. Proc Natl Acad Sci U S A 94, 3200-3205.

Kawano, Y., Noma, T., 1996. Role of interleukin-2 and interferon-gamma in inducing production of IgG subclasses in lymphocytes of human newborns. Immunology $88,40-48$

Kawano, Y., Noma, T., Yata, J., 1994. Regulation of human IgG subclass production by cytokines. IFN. gamma and IL- 6 act antagonistically in the induction of human IgG1 but additively in the induction of IgG2. J Immunol 153, 4948-4958.

Kirshner, S.L., Katz-Levy, Y., Wirguin, I., Argov, Z., Mozes, E., 1994. Fine specificity of T cell lines and clones that are capable of inducing autoimmune manifestations in mice. Cell Immunol 157, 11-28.

Lavrnic, D., Losen, M., Vujic, A., De Baets, M., Hajdukovic, L.J., Stojanovic, V., Trikic, R., Djukic, P., Apostolski, S., 2005. The features of myasthenia gravis with autoantibodies to MuSK. I Neurol Neurosurg Psychiatry 76, 1099-1102.

Leite, M.I., Jacob, S., Viegas, S., Cossins, 3., Clover, L., Morgan, B.P., Beeson, D., Willcox, N., Vincent, A., 2008. IgG1 antibodies to acetylcholine receptors in 'seronegative' myasthenia gravis. Brain 131 , 1940-1952.

Lindstrom, J., 1985. Immunobiology of myasthenia gravis, experimental autoimmune myasthenia gravis, and Lambert-Eaton syndrome. Annu Rev Immunol 3, 109-131.

Lindstrom, J., Shelton, D., Fujii, Y., 1988. Myasthenia gravis. Adv Immunol 42, 233-284 
Lindstrom, J.M., Lennon, V.A., Seybold, M.E., Whittingham, S., 1976. Experimental autoimmune myasthenia gravis and myasthenia gravis: biochemical and immunochemical aspects. Ann N Y Acad Sci 274, 254-274.

Link, J., Navikas, V., Yu, M., Fredrikson, S., Osterman, P.O., Link, H., 1994a. Augmented interferongamma, interleukin-4 and transforming growth factor-beta mRNA expression in blood mononuclear cells in myasthenia gravis. J Neuroimmunol 51, 185-192.

Link, J., Soderstrom, M., Ljungdahl, A., Hojeberg, B., Olsson, T., Xu, Z., Fredrikson, S., Wang, Z.Y., Link, H., 1994b. Organ-specific autoantigens induce interferon-gamma and interleukin-4 mRNA expression in mononuclear cells in multiple sclerosis and myasthenia gravis. Neurology 44, 728-734.

Losen, M., Martinez-Martinez, P., Phernambuca, M., Schuurman, J., Parren, P.W., De Baets, M.H., 2008. Treatment of myasthenia gravis by preventing acetylcholine receptor modulation. Ann N Y Acad Sci $1132,174-179$.

Losen, M., Stassen, M.H., Martinez-Martinez, P., Machiels, B.M., Duimel, H., Frederik, P., Veldman, H. Wokke, J.H., Spaans, F., Vincent, A., De Baets, M.H., 2005. Increased expression of rapsyn in muscles prevents acetylcholine receptor loss in experimental autoimmune myasthenia gravis. Brain 128 , 2327-2337.

Loutrari, H., Kokla, A., Tzartos, S.J., 1992. Passive transfer of experimental myasthenia gravis via antigenic modulation of acetylcholine receptor. Eur J Immunol 22, 2449-2452.

Martinez-Martinez, P., Losen, M., Duimel, H., Frederik, P., Spaans, F., Molenaar, P., Vincent, A., De Baets, M.H., 2007. Overexpression of rapsyn in rat muscle increases acetylcholine receptor levels in chronic experimental autoimmune myasthenia gravis. Am J Pathol 170, 644-657.

Miller, A., Shapiro, S., Gershtein, R., Kinarty, A., Rawashdeh, H., Honigman, S., Lahat, N., 1998. Treatment of multiple sclerosis with copolymer-1 (Copaxone): implicating mechanisms of Th1 to Th2/Th3 immune-deviation. J Neuroimmunol 92, 113-121.

Moiola, L., Galbiati, F., Martino, G., Amadio, S., Brambilla, E., Comi, G., Vincent, A., Grimaldi, L.M., Adorini, L., 1998. IL-12 is involved in the induction of experimental autoimmune myasthenia gravis, an antibody-mediated disease. Eur J Inımunol 28, 2487-2497.

Moiola, L., Protti, M.P., McCormick, D., Howard, J.F., Conti-Tronconi, B.M., 1994. Myasthenia gravis Residues of the alpha and gamma subunits of muscle acetylcholine receptor involved in formation of immunodominant CD4+ epltopes. J Immunol 152, 4686-4698.

Neuhaus, O., Farina, C., Yassouridis, A., Wiendl, H., Then Bergh, F., Dose, T., Wekerle, H., Hohlfeld, R. 2000. Multiple sclerosis: comparison of copolymer-1-reactive $T$ cell lines from treated and untreated subjects reveals cytokine shift from Thelper 1 to Thelper 2 cells. Proc Natl Acad Sci U S A 97, 74527457.

Osborn, M., Marx, A., Kirchner, T., Tzartos, S.J., Plessman, U., Weber, K., 1992. A shared epitope in the acetylcholine receptor-alpha subunit and fast troponin I of skeletal muscle. Is it important for myas thenia gravis? Am J Pathol 140, 1215-1223.

Paas-Rozner, M., Dayan, M., Paas, Y., Changeux, J.P., Wirguin, I., Sela, M., Mozes, E, 2000. Oral administration of a dual analog of two myastlyenogenic $T$ cell epltopes down-regulates experimental autoimmune nyasthenia gravis in mice. Proc Natl Acad Sci U S A 97, 2168-2173.

Paas-Rozner, M., Sela, M., Mozes, E, 2001. The nature of the active suppression of responses associated with experimental autoimmune myasthenia gravis by a dual altered peptide ligand administered by different routes. Proc Natl Acad Sci U S A 98, 12642-12647.

Paas-Rozner, M., Sela, M., Mozes, E., 2003. A dual altered peptide ligand down-regulates myasthenogenic $T$ cell responses by up-regulating CD25- and CTLA-4-expressing CD $4+T$ cells. Proc Natl Acad Sci USA 100, 6676-6681.

Papanastasiou, D., Poulas, K., Kokla, A., Tzartos, S.J., 2000. Prevention of passlvely transferred experimental autoimmune myasthenia gravis by Fab fragments of monoclonal antibodies directed against the main immunogenic region of the acetylcholine receptor. J Neuroimmunol 104, 124-132.

Rodgaard, A., Nielsen, F.C., Djurup, R., Somnier, F., Gammeltoft, S., 1987. Acetylcholine receptor antibody in myasthenia gravis: predominance of $\operatorname{lgG}$ subclasses 1 and 3. Clin Exp Immunol 67, 82-88. 


\section{CHAPTER 2}

Saoudi, A., Bernard, I., Hoedemaekers, A., Cautain, B., Martinez, K., Druet, P., De Baets, M., Guery, J.C., 1999a. Experimental autoimmune myasthenia gravis may occur in the context of a polarized Th1- or Th2-type immune response in rats. $J$ Immunol 162, 7189-7197.

Saoudi, A., Bernard, I., Hoedemaekers, A., Cautain, B., Martinez, K., Druet, P., De Baets, M., Guery, J.C., $1999 \mathrm{~b}$. Polarization toward the T-helper(Th) 1 type immune response is not required for rat experimental autoimmune myasthenia gravis. Transplant Proc 31, 1604-1605.

Saoudi, A., Guery, J.C., De Baets, M., 2000. Is pathogenic humoral autoimmunity a ThI response? Immunol Today 21, 306-307.

Saoudi, A., Kuhn, J., Huygen, K., de Kozak, Y., Velu, T., Goldman, M., Druet, P., Bellon, B., 1993. Role of the TH1-TH2 balance in the development of autoimmunity in rats. Transplant Proc 25, 2824-2825.

Seybold, M.E., 1987. Plasmapheresis in myasthenia gravis. Ann N Y Acad Sci 505, 584-587.

Tackenberg, B., Kruth, J., Bartholomaeus, J.E., Schlegel, K., Oertel, W.H., Willcox, N., Hemmer, B., Sommer, N., 2007. Clonal expansions of $C D 4+B$ helper $T$ cells in autoimmune myasthenia gravis. Eur J Immunol 37, 849-863.

Teitelbaum, D., Arnon, R, Sela, M., 1997. Cop 1 as a candidate drug for multiple sclerosis. J Neural Transm Suppl 49, 85-91.

Teitelbaum, D., Meshorer, A., Hirshfeld, T., Arnon, R., Sela, M., 1971. Suppression of experimental allergic encephalomyelitis by a synthetic polypeptide. Eur J Immunol 1, 242-248.

Toyka, K.V., Lowenadler, B., Heininger, K., Besinger, U.A., Birnberger, K.L., Fateh-Moghadam, A., Heilbronn, E., 1980. Passively transferred myasthenia gravis: protection of mouse endplates by Fab fragments from human myasthenic IgG. J Neurol Neurosurg Psychiatry 43, 836-840.

van der Neut Kolfschoten, M., Schuurman, J., Losen, M., Bleeker, W.K., Martinez-Martinez, P., Vermeulen, E., den Bleker, T.H., Wiegman, L., Vink, T., Aarden, L.A., De Baets, M.H., van de Winkel, J.G., Aalberse, R.C., Parren, P.W., 2007. Anti-inflammatory activity of human IgG4 antibodies by dynamic Fab arm exchange. Science 317, 1554-1557.

Wang, W., Ostlie, N.S., Conti-Fine, B.M., Milani, M., 2004. The susceptibility to experimental myasthenia gravis of STAT6-/- and STAT4-/-BALB/C mice suggests a pathogenic role of Th1, cells. J Immunol 172 , 97-103.

Wang, Z.Y., Okita, D.K., Howard, J., Jr., Conti-Fine, B.M., 1997. Th1 epitope repertoire on the alpha subunit of human muscle acetylcholine receptor in myasthenia gravis. Neurology 48, 1643-1653.

Wauben, M.H., Hoedemaekers, A.C., Graus, Y.M., Wagenaar, J.P., van Eden, W., de Baets, M.H., 1996. Inhibition of experimental autoimmune myasthenia gravis by major histocompatibility complex class II competitor peptides results not only in a suppressed but also in an altered immune response. Eur J Immunol 26, 2866-2875.

Yi, Q., Ahlberg, R., Pirskanen, R., Lefvert, A.K., 1994. Acetylcholine receptor-reactive T cells in myasthenia gravis: evidence for the involvement of different subpopulations of T helper cells. J Neuroimmuno $50,177-186$.

Zhang, G.X., Xiao, B.G., Yu, L.Y, van der Meide, P.H., Link, H., 2001. Interleukin 10 aggravates experimental autoimmune myasthenia gravis through inducing $T h 2$ and $B$ cell responses to $A C h R$. J Neuroimmunol 113, 10-18.

Zhang, K., 2003. Accessibility control and machinery of immunoglobulin class switch recombination. Leukoc Blol 73, 323-332. 
IMMUNOWOOUATOMY EFFCA OFPT262 IN EAMG

Table 1. Peptide sequence alignment of PTR262 compared to Torpedo callfornica, mouse, rat and human peptide sequence of the AChR $\alpha$-subunit.

\begin{tabular}{|c|c|c|}
\hline Peptide sequence AChR $\alpha$-subunit & Sequence $p 195-212$ & Sequence p 259-271 \\
\hline Torpedo californica & DTPYLDITYHFIMQRIPL & VIVELIPSTSSAV \\
\hline Mouse & TTPYLDITYHFVMQRLPL & VIVELIPSTSSAV \\
\hline Rat & NTPYLDITYHFVMQRLPL & VIVELIPSTSSAV \\
\hline Human & DTPYLDITYHFVMQRLPL & VIVELIPSTSSAV \\
\hline PTR262 & DTPYLDITYHFVAQRLPL & VIVKLIPSTSSAV \\
\hline PTR262 full sequence & VIVKLIPSTSSAVDTPYLDIT & QRLPL \\
\hline
\end{tabular}

The peptide sequence of PTR262, which is based on the human AChR $\alpha 1$-subunit, has been altered on two positions. Glutamic acid (E) is replaced by Lysine (K) on position 262 and Methionine (M) is replaced by Alanine (A) on position 207. 
CHAPTER 2

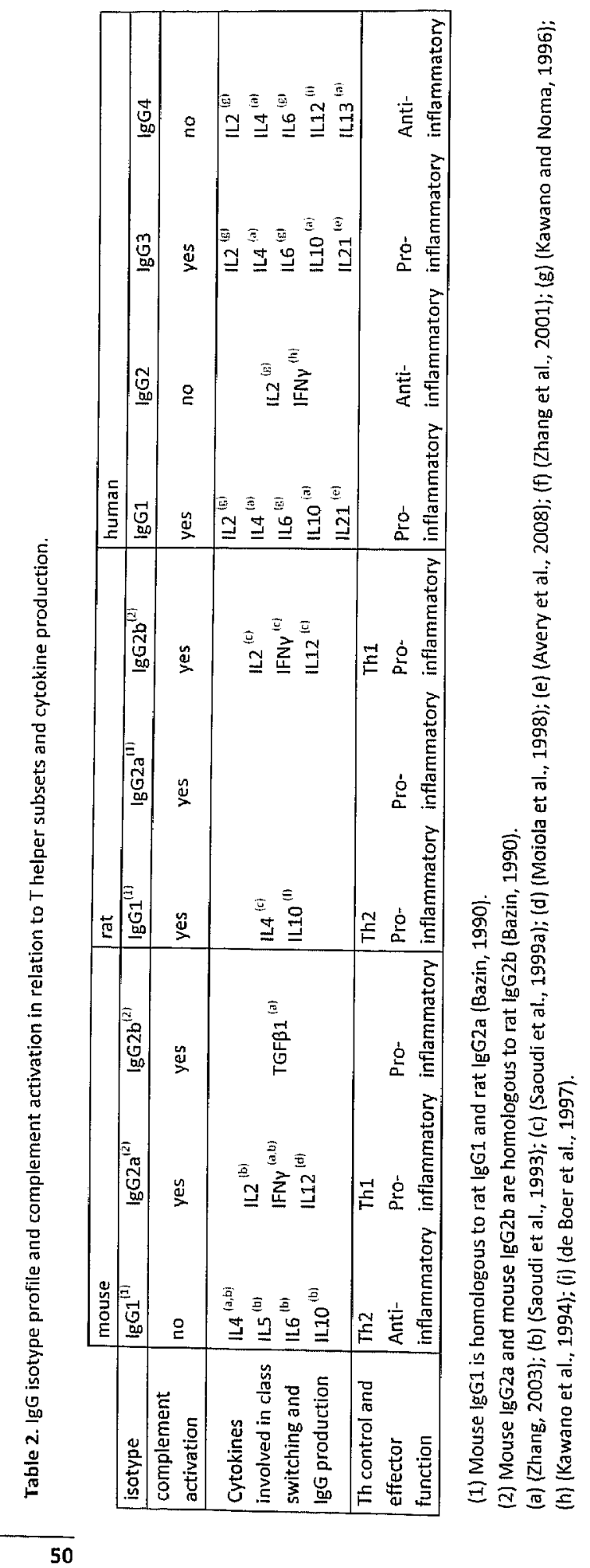


Table 3. Body weight and clinical score 8 weeks after immunization with $t A C h R$.

\begin{tabular}{|c|c|c|c|c|c|c|c|}
\hline & & \multirow{2}{*}{$>10 \%$ weight loss ${ }^{1}$} & \multirow{2}{*}{ average weight $(g)^{\prime}$} & \multicolumn{4}{|c|}{ clinical score } \\
\hline & & & & 0 & 1 & 2 & 3 \\
\hline Control & $(n=6)$ & 0 & 197.3 & 6 & 0 & 0 & 0 \\
\hline Vehicle EAMG & $(n=25)$ & 4 & 191.9 & 9 & 5 & 7 & 4 \\
\hline PTR EAMG & $(n=25)$ & 5 & 186.6 & 6 & 9 & 7 & 3 \\
\hline
\end{tabular}

'Severe weight loss was observed in PTR as well as vehicle-treated EAMG rats. Average weights were comparable in all groups $(p=0.24)$.

'The clinical severity of EAMG was scored on a scale ranging from 0 (no obvious abnormalities) to 3 (severe dinical signs present before testing). The difference between the clinical score of PTR EAMG rats $(1.24 \pm 1.28)$ and vehicle EAMG rats $(1.28 \pm 0.97)$, was not significant $(p=0.89)$.

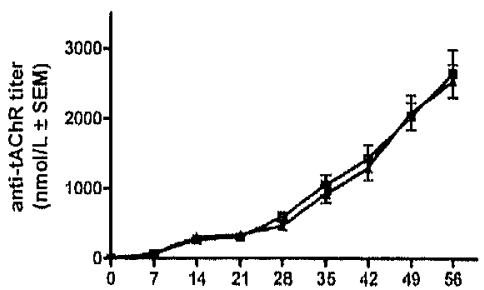

B

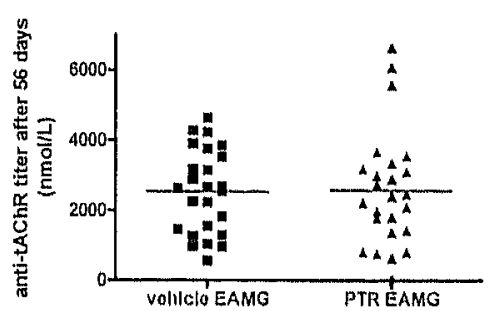

C

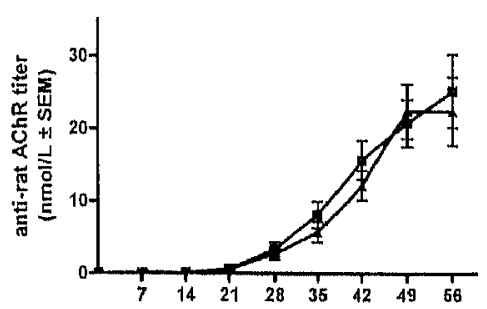

$\mathrm{D}$

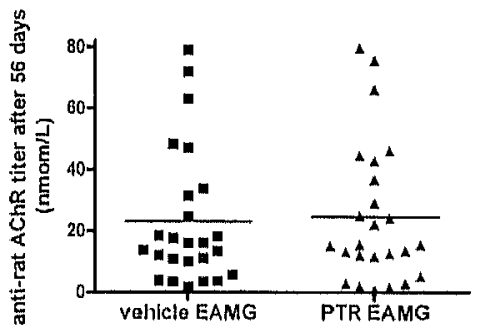

Figure 1. Anti-AChR antibody titers in EAMG rats. A, B; serum anti-tAChR antibody titers. C, D: serum antirat $A C h R$ antibody titers. The upper panels $(A * C)$ represent the average values during the whole time course of the experiment; the lower panels $(B+D)$ represent the individual and the average (horizontal bar) values after 8 weeks of treatment. Titers of vehicle-treated EAMG are represented as closed squares; titers of PTR-treated EAMG rats as closed triangles. At the end of the experiment no significant differences were observed between both EAMG groups in means of anti-tAChR antibody titer $(p=0.92)$ or anti-rat $A C h R$ titer $(p=0.81)$. 


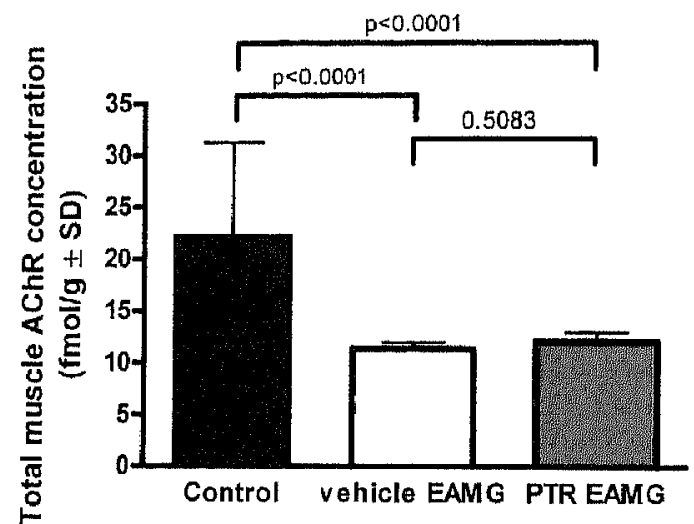

Figure 2. Total muscle AChR concentrations in tibialis anterior muscles. Both in the vehicle $(11.3 \pm 3.1$ $\mathrm{fmol} / \mathrm{g})$ as well as in the PTR262-treated EAMG group (12.0 $\pm 4.3 \mathrm{fmol} / \mathrm{g})$, AChR levels were significantly reduced by $\approx 50 \%$ compared to control muscles $(22.3 \pm 8.9 \mathrm{fmol} / \mathrm{g})(p<0.001)$. No significant difference could be observed between PTR262-treated EAMG rats and vehicle-treated EAMG rats $(p=0.52)$.

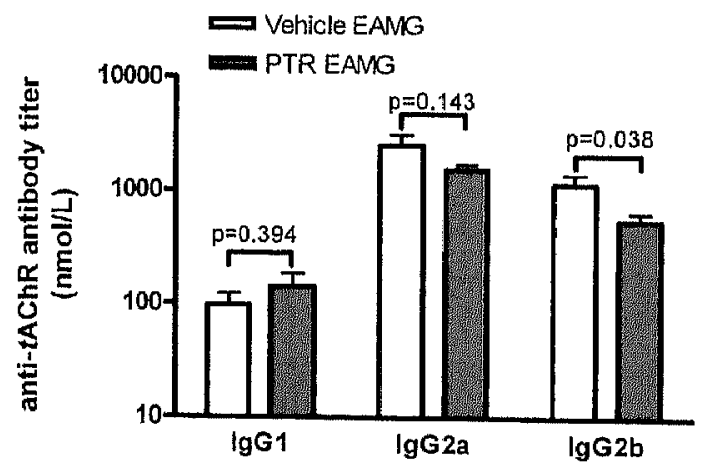

Figure 3. Analysis of isotype profile of anti-tAChR antibodies in EAMG rats. The distribution of the antitAChR IgG1, IgG2a and IgG2b isotypes was measured in the serum of EAMG rats 8 weeks after immunization. Anti-tAChR antibodies were measured by ELISA and the results are expressed as mean titers PTR262-treated rats (grey bars), show a significant decrease in antibodies of the lgG2b isotype compared to vehicle-treated rats (white bars). There were no significant differences of the average IgG1 and IgG2a anti-tAChR titers between both EAMG graups. 


\section{Chapter 3}

\section{CTLA polymorphisms are not associated with myasthenia gravis in Dutch pactents}

Marko Phernambucq, Arend Hamming, Mario Losen, Pilar Martínez-Martínez, Jan Damoiseaux, Mario Losen, Sofie Janssen, Ludo van der Pol and Marc H. De Baets 


\section{Introduction}

Myasthenia gravis (MG) is an autoimmune disease, characterized by fluctuating muscle weakness usually caused by the presence of autoantibodies directed against the acetylcholine receptor (Fambrough et al., 1973; Hoch et al., 2001). As in most autoimmune diseases, genetic heterogeneity may contribute to disease susceptibility and severity. For example human leukocyte antigen (HLA) haplotypes have been found associated with MG (Behan, 1980; Giraud et al., 2001; Pirskanen, 1976). Several other immune-modulating genes have been found associated with MG as well, including the cytotoxic T-lymphocyte-associated protein 4 (CTLA-4 gene) (Chuang et al., 2005; Wang et al., 2002b).

The CTLA-4 (CD152) gene at chromosome 2q33, is expressed on the surface of activated T-cells. It plays an important role in the regulation of the immune response (Krummel and Allison, 1995). One proposed mechanism is antagonism of CD28/B7dependent stimulation of T-cells. $B 7$, which is presented on the surface of antigen presenting cells has a higher affinity for CTLA-4 than for CD28. A second mechanism is the negative signaling upon TCR activation, which leads to anergy of the T cells. (Carreno et al., 2000).

The CTLA-4 gene displays several polymorphisms in the promoter region, i.e. -1722 $C / T,-1661 \mathrm{~A} / \mathrm{G}$ (Hudson et al., 2002), $-318 \mathrm{C} / \mathrm{T}$ (Deichmann et al., 1996), and a +49 A/G (Harper et al., 1991), polymorphism at exon 1. Polymorphisms in the CTLA-4 promoter region and in exon 1 influence surface expression of the receptor (Kouki et al., 2000; Ligers et al., 2001). Previous studies have shown CTLA-4 polymorphisms to be associated with several autoimmune diseases, including insulin dependent diabetes mellitus (IDDM), Graves' disease, Hashimoto's thyroiditis and rheumatoid arthritis (RA).

Wang et al (Wang et al., 2002b) have shown a weak association of the $+49 \mathrm{~A} / \mathrm{G}$ genotype and $M G$ in a Swedish cohort of Swedish Caucasian patients. Another study (Chuang et al., 2005) reported an association of the +49 A/G genotypes and the occurrence of $M G$ in patients with thymoma. To study the association of genetic heterogeneity of the CTLA-4 gene in more detail, we determined $-1722 \mathrm{C} / \mathrm{T},-1661$ $A / G,-318 \mathrm{C} / T$, and $+49 \mathrm{~A} / \mathrm{G}$ genotypes of 97 Dutch patients with serpositive $M G$ and 168 healthy controls.

\section{Patients, materials and methods}

\section{Patients and controls}

The 107 patients with MG recruited for this study were seen at the outpatient clinics of the University hospitals in Maastricht, Groningen and Utrecht, The Nether- 
lands. Serum samples from all included patients contained antibodies against the acetylcholine receptor. Patients were described previously by van der Pol and colleagues (van der Pol et al., 2003). One hundred sixty-eight healthy volunteers were recruited as controls. The characteristics of both groups are summarized in Table 1.

\section{DNA extraction and CTLA-4 genotyping}

EDTA- or heparin-anticoagulated venous blood samples were drawn from patients and controls. DNA was amplified using the Faststart Taq DNA polymerase kit (Roche, Basel, Switzerland). For CTLA-4 genotyping polymerase chain reaction (PCR) followed by restriction fragment length polymorphism (RFLP) was performed. Primer sequences are listed in Table 2 (Sigma St. Louis, MO). Genomic DNA was added to a $P C R$ reaction mix of $25 \mu \mathrm{l}$, containing $5 \mathrm{mMol} d N T P^{\prime} \mathrm{s}, 10 \% 10 \times$ PCR buffer from the kit, $0.02 \mathrm{U} / \mu \mathrm{l}$ faststart Taq polymerase, $0.4 \mathrm{pMol} / \mu \mathrm{l}$ forward primer, $0.4 \mathrm{pMol} / \mu \mathrm{l}$ reverse primer and 1.5 to $2.0 \mathrm{mMol} / \mu \mathrm{l}$ of $25 \mathrm{mM} \mathrm{MgCl}_{2}$ diluted in $\mathrm{H}_{2} \mathrm{O}$. PCR condjtions consisted of 35 cycles in the GeneAmp PCR system 2700 (Applied Biosystems Foster City, CA). The PCR process consisted of incubation at $94^{\circ} \mathrm{C}$ for 10 minutes. This was followed by 35 cycles of denaturation at $94^{\circ} \mathrm{C}$ for $30 \mathrm{~s}$, annealing at $57^{\circ} \mathrm{C}$ for the $-1772 /-1662$ polymorphisms and $58^{\circ} \mathrm{C}$ for the -318 and +49 polymorphisms, both for 30 seconds and elongation at $72^{\circ} \mathrm{C}$ for $30 \mathrm{~s}$. After the cycles followed final extension at $72^{\circ} \mathrm{C}$ for 10 minutes and then a hold phase at $4^{\circ} \mathrm{C}$. The amplification reactions yielded a 486 base pair (bp) product containing the -1661 and -1722 , a 247 bp product containing the -318 polymorphism and a $160 \mathrm{bp}$ product containing the +49 polymorphism. Digestion of the PCR product was performed with the Msel restriction enzyme (New England Biolabs, Ipswitch, $M A$ ) for the $-1.661 \mathrm{~A} / \mathrm{G}$ and -318 $\mathrm{C} / \mathrm{T}$ polymorphisms and BseXI (Fermentas, Ontario, Canada) for the $-1722 \mathrm{C} / \mathrm{T}$ and the $+49 \mathrm{~A} / \mathrm{G}$ polymorphisms. The digestion products were analyzed by electrophoresis using a 3.5\% agarose gel with gelstar (Cambrex Bio Science, Rockland, MA). In order to make the digestion phase reproducible and to allow for mass pipetting, the PCR machine was reprogrammed to also perform the digestion.

\section{Statistics}

Statistical analysis was carried out using the Statistical Package for the Social Sciences (SPSS, version 12.01). Genotype frequencies were compared between patients and controls using Chi-square test ( $3 \times 2$ and $2 \times 2$ contingency tables) or Fisher's exact test where appropriate. Relative risks were calculated according to Woolf with Haldane's continuity correction (Haldane, 1956; Woolf, 1955). Only corrected $P$ values below 0.05 were considered significant. Patients with an age over 40 were considered late-onset and ages up to and including 40 were considered early-onset. Cases with incomplete genotyping data were excluded. An analysis 
with a variable-by-variable deletion of missing values was also performed. Since it is not clear whether the prevalence of individual alleles can be considered a measure without taking in account the genotype of a person, this analysis was not done.

\section{Results}

Complete genotyping results were obtained from 97 patients. Ten cases with incomplete genotyping data were excluded from the initial analysis. Table 3 shows that frequencies of none of the 4 CTLA-4 genotypes differed significantly between controls and MG patients. Variable-by-variable deletion of missing values analysis gave ( $n=107$ ) similar results. Relative risks of each genotype were calculated and are summarized Table 4, Variable-by-variable based analysis for missing data yielded equivalent results.

The results from the thymoma subgroup are summarized in Table 4 . The frequency of the $-318 \mathrm{C} / \mathrm{T}$ genotype was increased among MG patients with thymoma as compared to controls with a relative risk of $2.333(1.042-5.223)$. This result can, however not be considered significant when correcting for the number of tests performed.

The MG and the control group did not differ significantly in $\operatorname{sex}(p=0.549)$. However, the MG patients were older than the controls. If controls of 40 and younger were excluded to create groups with an equal mean age, only 69 controls remained. Again no significant relative risks were found.

of the MG group 51 patients were early-onset and 46 late-onset. Comparing earlyonset patients with controls or late-onset patients showed no significant difference between the groups, with no relative risks differing significantly from 1 . One exception was found: the $-1661 \mathrm{G} / \mathrm{G}$ genotype was not found in the early-onset group, as opposed to 3 times $(6.5 \%)$ in the late-onset and 9 times $(5.4 \%)$ in the controls. Again, considering the number of tests performed this result is coincidental.

The $+49 \mathrm{G} / \mathrm{A}$ genotype was a significant risk factor for developing MG in patients with a high titer (more than $30 \mathrm{nMol} / \mathrm{l}, \mathrm{n}=22$ ) with a relative risk of 1.504 $(1.013-2.233)$ when compared to the controls. When patients with a low titer of $8 \mathrm{nMol} / \mathrm{l}(\mathrm{n}=30)$ were compared with the controls and with the patients with a high titer no significant relative risks were found. Comparing male and female patients with controls and with each other also showed no significant relative risks. 


\section{Discussion}

CTLA-4 plays a critical role in the regulation of T-cell activation. It exerts its function via two different mechanisms. The first mechanism acts through intervening in the $C D 28: B 7$ mediated co stimulation. Binding of $C D 28$ to the $B 7$ receptor is necessary in $T$ cells for cell cyclus progression, IL-2 production and $\mathrm{LL}-2$ receptor production. CTLA-4 upregulation results in competition of CTLA-4 with CD28 for binding the B7 receptor, because the affinity of the CTLA-4:B7 interaction is more than 10 times higher than the affinity of the CD28:B7 interaction. This results in a block of CD28 dependent responses and in arrest of the cell cyclus (Thompson and Allison, 1997). A second mechanism by which CTLA-4 inhibits $T$ cell responses is by delivery of a negative signal to the $T$ cell upon $T$ cell receptor activation [7].

A crucial factor in the pathology of many autoimmune diseases is the regulation of the T cell activation. This explains why CTLA-4 expression is involved in the pathogenesis of insulin dependent diabetes mellitus (IDDM), rheumatoid arthritis (RA), and other autoimmune diseases (Braun et al., 1998; Donner et al., 1997a; Donner et al., 1997b; Donner et al., 1998; Marron et al., 1997; Seidl et al., 1998; Yanagawa et al., 1995). The role of CTLA-4 in the pathogenesis of MG has is not clear yet, however Wang and colleagues reported that treatment with anti-CTLA-4 antibody enhances murine myasthenia gravis (Wang et al., 2001). This strongly indicates the significance of CTLA-4 in MG progression.

In this study we investigated if CTLA-4 polymorphisms influence susceptibility for MG. In previous studies it was reported that CTLA-4 polymorphisms are associated with autoimmune disorders including RA and MS. Studies on the frequencies of CTLA-4 genotypes in cohorts of patients with MG were inconclusive. In this study we found no association of any of the known CTLA-4 polymorphisms with MG. However, in this study the frequency of the $-318 \mathrm{C} / \mathrm{T}$ genotype was increased among patients with $M G$ and thymoma. A possible explanation for this result is that the $318 \mathrm{C} / \mathrm{T}$ is located in the promoter region of CTLA-4 and Wang et al, reported that the presence of the 318 allele was associated with a higher promoter activity (Wang et al., 2002c). The $-318 \mathrm{~T}$ allele may thus contribute to upregulation of the CTLA-4 expression and consequently represent one mechanism to inhibit exaggerated immune activity.

Previous studies also reported an increase of the $+49 \mathrm{G} / \mathrm{G}$ genotype among patients with MG and thymoma as compared to patients with MG without thymoma (Huang et al., 2000; Wang et al., 2002a).

Another study (Chuang et al., 2005) reported an inverse association: the +49 A/A genotype predisposed for paraneoplastic MG in thymoma patients. We could not corroborate these findings in our study. Although it should be noted that our patient group contains less thymoma patients than the study by Chuang and colleagues only one $(5.6 \%)$ out of 15 thymoma patients had the $+49 \mathrm{G} / \mathrm{G}$ genotype. The 
frequency of the +49 A/A genotype did not differ between thymoma patients (42\%) and controls (46\%) (Chuang et al., 2005).

\section{References}

Anjos, S., Polychronakos, C., 2004. Mechanisms of genetic susceptibility to type I diabetes: bevond HLA. Mol Genet Metab 81, 187-195.

Behan, P.O., 1980. Immune disease and HLA associations with myasthenia gravis. I Neurol Neurosurg Psychiatry 43, 611-621.

Braun, J., Donner, H., Siegmund, T., Walfish, P.G., Usadel, K.H., Badenhoop, K., 1998. CTLA-4 promoter variants in patients with Graves' disease and Hashimoto's thyroiditis. Tissue Antigens 51, 563-566.

Carreno, B.M., Bennett, F., Chau, T.A., Ling, V., Luxenberg, D., Jussif, J., Baroja, M.L., Madrenas, J., 2000. CTLA-4 (CD152) can inhibit T cell activation by two different mechanisms depending on its level of cell surface expression. $J$ Immunol 165, 1352-1356.

Chuang, W.Y., Strobel, P., Gold, R., Nix, W., Schalke, B., Kiefer, R., Opitz, A., Klinker, E., Muller-Hermelink, H.K., Marx, A., 2005. A CTLA4high genotype is associated with myasthenia gravis in thymoma pa. tients. Ann Neurol 58, 644-648.

Deichmann, K., Heinzmann, A., Bruggenolte, E, Forster, J., Kuehr, J., 1996. An Mse I RFLP in the human CTLA4 promotor. Biochem Biophys Res Commun 225, 817-818.

Donner, H., Braun, J., Seidl, C., Rau, H., Finke, R., Ventz, M., Walfish, P.G., Usadel, K.H., Badenhoop, K., 1997a. Codon 17 polymorphism of the cytotoxic T lymphocyte antigen 4 gene in Hashinoto's thyroiditis and Addison's disease. J Clin Endocrinol Metab 82, 4130-4132.

Donner, H., Rau, H., Walfish, P.G., Braun, J., Siegmund, T., Finke, R., Herwig, J., Usadel, K.H., Badenhoop, K., 1997b. CTLA4 alanine-17 confers genetic susceptibility to Graves' disease and to type 1 diabetes mellitus. J Clin Endocrinol Metab 82, 143-146.

Donner, H., Seidi, C., Braun, J., Siegmund, T., Herwig, J., Seifried, E., Usadel, K.H., Badenhoop, K., 1998. CTLA4 gene haplotypes cannot protect from IDDM in the presence of high-risk HLA DQ8 or DQ2 alleles in German families. Diabetes 47, 1158-1160.

Fambrough, D.M., Drachman, D.B., Satyamurti, S., 1973. Neuromuscular junction in myasthenia gravis: decreased acetylcholine receptors. Science 182, 293-295.

Giraud, M., Beaurain, G., Yamamoto, A.M., Eymard, B., Tranchant, C., Gajdos, P., Garchon, H.J., 2001. Linkage of HLA to myasthenia gravis and genetic heterogeneity depending on ant-titin antibodies. Neurology 57, 1555-1560.

Haldane, J.B., 1956. The estimation and significance of the logarithm of a ratio of frequencles. Ann Hum Genet 20, 309-311.

Harper, K., Balzano, C., Rouvier, E, Mattei, M.G., Luciani, M.F., Golstein, P., 1991. CTLA-4 and CD28 activated lymphocyte molecules are closely related in both mouse and human as to sequence, message expression, gene structure, and chromosomal location. J Immunol 147, 1037-1044.

Hoch, W., McConville, J., Helms, 5., Newsom-Davis, J., Melms, A., Vincent, A., 2001. Auto-antibodies to the receptor tyrosine kinase MuSK in patients with myasthenia gravis without acetylcholine receptor antibodies. Nat Med 7, 365-368.

Huang, D., Giscombe, R., Zhou, Y., Pirskanen, R., Lefvert, A.K., 2000. Dinucleotide repeat expansion in the CTLA-4 gene leads to $T$ cell hyper-reactivity via the CD28 pathway in myasthenla gravis. J Neuroimmunol 105, 69-77.

Hudson, L.L., Rocca, K., Song, Y.W., Pandey, J.P., 2002. CTLA-4 gene polymorphisms in systemic lupus erythematosus: a highly significant association with a determinant in the promoter region. Hum Genet $111,452-455$. 
Kouki, T., Sawai, Y., Gardine, C.A., Fisfalen, M.E., Alegre, M.L., DeGroot, L.J., 2000. CTLA-4 gene polymorphism at position 49 in exon 1 reduces the inhibitory function of CTLA-4 and contributes to the pathogenesis of Graves' disease. J Immunol 165, 6606-6611.

Krummel, M.F., Allison, J.P., 1995. CD28 and CTLA-4 have opposing effects on the response of T cells to stimulation. J Exp Med 182, 459-465.

Ligers, A., Teleshova, N., Masterman, T., Huang, W.X., Hillert, J., 2001. CTLA-4 gene expression is influenced by promoter and exon 1 polymorphisms. Genes Immun 2, 145-152.

Marron, M.P., Raffel, L.J., Garchon, H.J., Jacob, C.O., Serrano-Rios, M., Martinez Larrad, M.T., Teng, W.P., Park, Y., Zhang, Z.X., Goldstein, D.R., Tao, Y.W., Beaurain, G., Bach, J.F., Huang, H.S., Luo, D.F., Zeidler, A., Rotter, J.I., Yang, M.C., Modilevsky, T., Maclaren, N.K., She, J.X., 1997. Insulin-dependent diabetes mellitus (IDDM) is associated with CTLA4 polymorphisms in multiple ethnic groups. Hum Mol Genet 6, 1275-1282.

Pirskanen, R., 1976. On the significance of HL-A and LD antigens in myasthenia gravis. Ann N Y Acad Sc $274,451-460$.

Seidl, C., Donner, H., Fischer, B., Usadel, K.H., Seifried, E., Kaltwasser, J.P., Badenhoop, K., 1998. CTLA4 codon 17 polymorphism in patients with rheumatoid arthritis. Tissue Antigens 51, 62-66.

Thompson, C.B., Allison, J.P., 1997. The emerging role of CTLA-4 as an immune attenuator. Immunity 7 , 445-450.

van der Pol, W.L., Jansen, M.D., Kuks, J.B., de Baets, M., Leppers-van de Straat, F.G., Wokke, J.H., van de Winkel, J.G., van den Berg, L.H., 2003. Association of the FC gamma receptor IIA-R/R131 genotype with myasthenia gravis in Dutch patients. J Neuroimmunol 144, 143-147.

Wang, H.B., Shi, F.D., Li, H., Chambers, B.J., Link, H., Ljunggren, H.G., 2001. Antl-CTLA-4 antibody treatment triggers determinant spreading and enhances murine myasthenia gravis. J Immunol 166, 6430 6436.

Wang, X.B., Giscombe, R., Yan, Z., Heiden, T., Xu, D., Lefvert, A.K., 2002a. Expression of CTLA-4 by human monocytes. Scand I Immunol 55, 53-60.

Wang, X.B., Kakoulidou, M., Qiu, Q., Giscombe, R., Huang, D., Pirskanen, R., Lefvert, A.K., 2002b. CDS1 and promoter single nucleotide polymorphisms of the CTLA-4 gene in human myasthenia gravis. Genes immun 3, 46-49.

Wang, X.B., Zhao, X., Giscombe, R., Lefvert, A.K., 2002c. A CTLA-4 gene polymorphism at position -318 in the promoter region affects the expression of protein. Genes Immun 3, 233-234.

Woolf, B., 1955. On estimating the relation between blood group and disease. Ann Hum Genet 19, 251253.

Yanagawa, T., Hidaka, Y., Guimaraes, V., Soliman, M., DeGroot, L.J., 1995. CTLA-4 gene polymorphism assoclated with Graves' disease in a Caucasian population. J Clin Endocrinol Metab 80, 41-45. 
CHAPTH 3

Table 1: Clinical characteristics of the MG patients and controls.

\begin{tabular}{lll}
\hline & $\begin{array}{c}\text { Patients } \\
N=97\end{array}$ & $\begin{array}{c}\text { Controls } \\
N=168\end{array}$ \\
\hline Gender: $n(\%)$ & $37(38 \%)$ & $66(42 \%)$ \\
Male & $60(62 \%)$ & $93(58 \%)$ \\
Female & & \\
Age at onset & $46(47 \%)$ & \\
Early (25-40) & $51(53 \%)$ & \\
Late (41-90) & & \\
Thymoma & & \\
Present & $15(15 \%)$ & \\
Absent & & \\
\hline
\end{tabular}

Table 2 The forward and reverse primer sequences, which were used for sequencing of the polymorphisms.

$-1722$

\begin{tabular}{ll} 
forward & 5' CTA AGA GCA TCC GCT TGC ACC T 3' \\
reverse & 5' TTG GTG TGA TGC ACA GAA GCC TTT T 3' \\
\hline-1661 & 5' CTA AGA GCA TCC GCT TGC ACC T 3' \\
forward & 5' TTG GTG TGA TGC ACA GAA GCC TTT T 3' \\
reverse & 5' AAA TGA ATT GGA CTG GAT GGT 3' \\
\hline -318 & 5' TTA CGA GAA AGG AAG CCG TG 3' \\
forward & \\
reverse & 5' GCT CTA CTT CCT GAA GAC CT 3' \\
\hline +49 & 5' AGT CTC ACT CAC CTT TGC AG 3' \\
forward & \\
\hline
\end{tabular}


Table 3 Correlation of genotypes between MG patients and controls. Note there is no significant correlation.

\begin{tabular}{ll}
\hline & Fisher $/$ Chi $^{2}$ (sig) \\
\hline$-1722 \mathrm{C} / \mathrm{T}$ & $0.964(0.617)$ \\
$-1661 \mathrm{~A} / \mathrm{G}$ & $0.981(0.612)$ \\
$-318 \mathrm{C} / \mathrm{T}$ & $0.000(1.000)$ \\
$+49 \mathrm{~A} / \mathrm{G}$ & $0.984(0.611)$ \\
\hline
\end{tabular}

Table 4 Overview of the relative risks, calculated for each polymorphism in MG patjents and in MG patients with a thymoma.

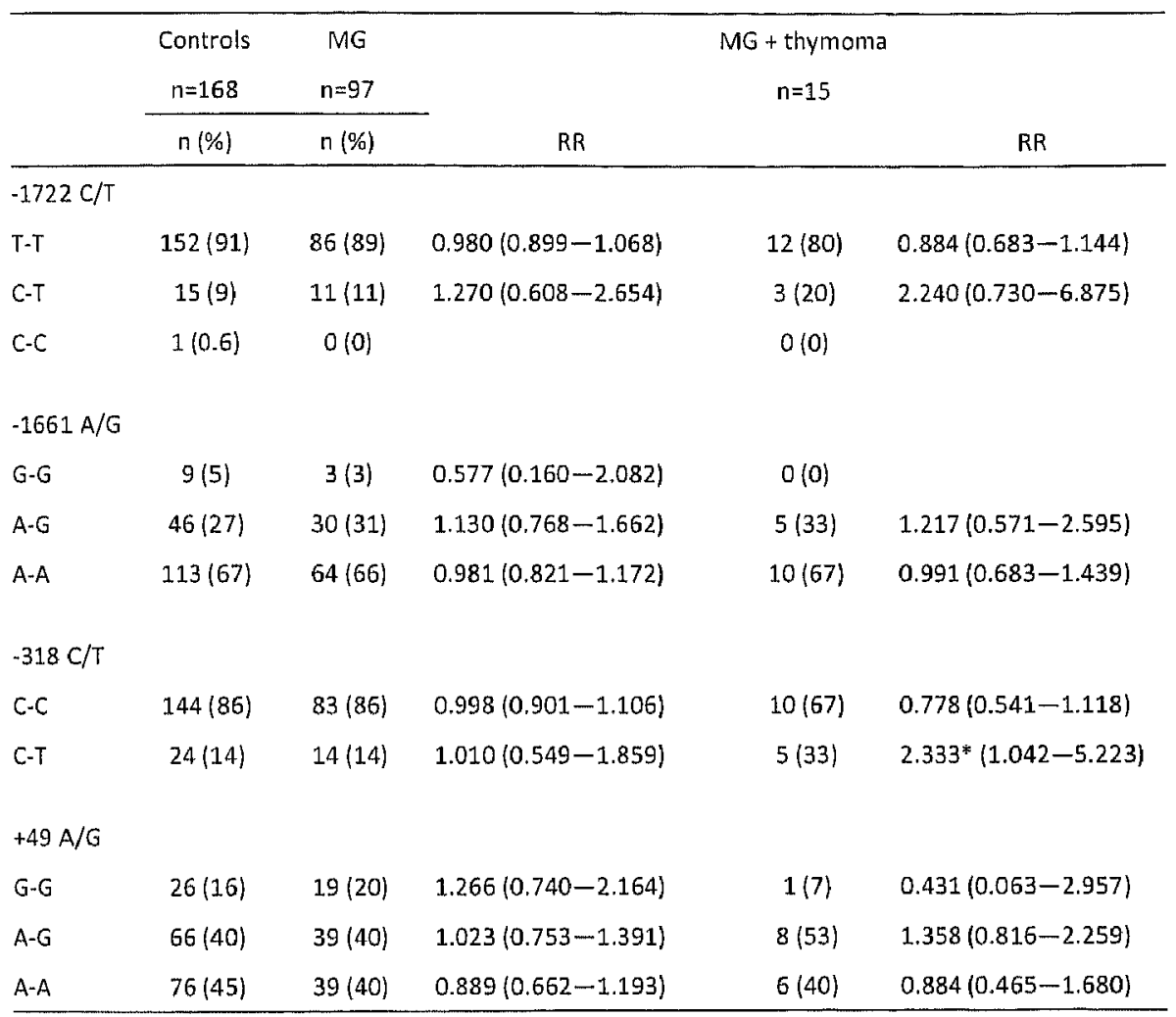

$*(p<0.05)$ 


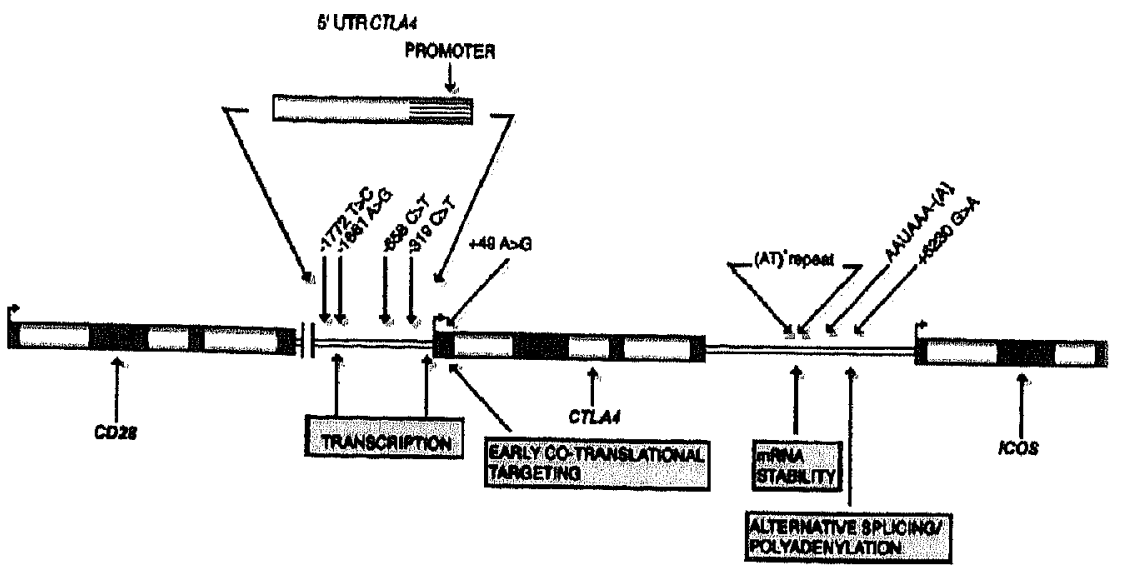

Figure1. Genetic map of the CTLA-4 gene and the location of potential disease associated polymorphisms. SNPs and their possible functional significance are indicated, as is the (AT)" repeat and the predicted polyadenylation site for the major CTLA-4 transcript. SNPs in the 5 flanking region and in the promoter region are indicated as is the minimal promoter region ( $335 \mathrm{bp}$ ); only the C-318T SNP is located within this minimal region.

Figure derived and adjusted from Anjos and colleagues. (Anjos and Polychronakos, 2004) . 


\title{
Chapter 4
}

\author{
silencing rapsyn in wivo decreases \\ acetylcholine receptors and augments \\ sodium channels and secondary \\ postsynaptic membrane folding
}

Pilar Martínez-Martínez, Marko Phernambucq, Laura Steinbusch, Laurent Schaeffer, Sonia Berrih-Aknin, Hans Duimel, Peter Frederik, Peter Molenaar, Marc H. De Baets and Mario Losen 


\section{Abstract}

The receptor-associated protein of the synapse (rapsyn) is required for anchoring and stabilizing the nicotinic acetylcholine receptor (AChR) in the postsynaptic membrane of the neuromuscular junction (NMJ) during development. Here we studied the role of rapsyn in the maintenance of the adult NMJ by reducing rapsyn expression levels with short hairpin RNA (shRNA). Silencing rapsyn led to the average reduction of the protein levels of rapsyn ( $31 \%$ loss) and AChR (36\% loss) at the NMJ within 2 weeks, corresponding to previously reported half life of these proteins. On the other hand, the sodium channel protein expression was augmented (66\%) in rapsyn-silenced muscles. Unexpectedly, at the ultrastructural level a significant increase in the amount of secondary folds of the postsynaptic membrane in silenced muscles was observed. The neuromuscular transmission in rapsyn-silenced muscles was mildly impaired. The results suggest that the adult NMJ can rapidly produce postsynaptic folds to compensate for AChR and rapsyn loss. 


\section{Introduction}

The postsynaptic apparatus of the skeletal neuromuscular junction (NMJ) is specialized to respond continuously and accurately to the neurotransmitter acetylcholine (ACh) released from the overlying nerve terminal. The acetylcholine receptor (AChR) is clustered at high density in the postsynaptic membrane by the receptorassociated protein of the synapse (rapsyn). Rapsyn is required for the organization of the developing NMJ since rapsyn-deficient mice lack differentiated NMJs and die shortly after birth (Gautam et al., 1995). In these mice, both presynaptic and postsynaptic abnormalities were found, including the lack of AChR clusters, lack of postsynaptic membrane folding, excessive nerve sprouting and decreased nerve terminal arborization.

Mutations in the promoter or the coding sequence of the human RAPSN gene can cause congenital myasthenic syndromes (CMS). Decreased recruitment of AChR to rapsyn clusters, as well as decreased rapsyn expression at the endplate is likely to account for the endplate AChR deficiency (Cossins et al., 2006; Engel and Sine, 2005; Hantai et al., 2004; Maselli et al., 2003a; Ohno et al., 2002) resulting in impaired neuromuscular transmission. In patients with the N88K rapsyn-mutation (either homozygous or heteraallelic with other missense or promoter mutations) simplified postsynaptic membranes with few folds were found (Ohno et al., 2002; Ohno et al., 2003).

The AChR clustering by rapsyn is strongly enhanced by nerve agrin (Brockhausen et al., 2008; Nitkin et al., 1987), which acts via Irp4, the receptor for agrin, and the muscle specific tyrosine kinase (MUSK) (DeChiara et al., 1996; Kim et al., 2008; Zhang et al., 2008). Agrin increases the half life of the AChR from 1 day to 10 days in muscle fibers (Bezakova et al., 2001). This process is entirely dependant on rapsyn, since silencing rapsyn in vivo completely prevents agrin-induced AChR clustering (Kong et al., 2004). Agrin deficient mice show very similar pre- and postsynaptic structural abnormalities as rapsyn deficient mice (Gautam et al., 1996). In MMP3 null mice, which have increased synaptic levels of agrin, increased postsynaptic membrane folding has been observed (VanSaun et al., 2003). These observations suggest the possibility that agrin enhances both pre- and postsynaptic specialization via rapsyn. In line with this idea, B-catenin, which interacts directly with rapsyn (Zhang et al., 2007), is required for retrograde signaling from the muscle to the nerve to ensure normal nerve branching in the muscle, normal localization of nerve terminals in narrow endplate bands and efficient acetylcholine release ( $L j$ et al., 2008).

Because rapsyn is crucial for the stabilization of the AChR it might also play a role in the autoimmune disease myasthenia gravis (MG) where auto-antibodies against the $A C h R$ reduce the number of functional AChRs at the postsynaptic membrane (Toyka et al., 1975). In rats and mice, expression of rapsyn increases with age 
(Brockhausen et al., 2008; Gervasio et al., 2007; Hoedemaekers et al., 1998) and thereby stabilizes the AChR (Gervasio and Phillips, 2005). In a passive transfer rat model for $M G$, increased expression of rapsyn at the $N M J$ induces resistance against anti-AChR antibodies (De Baets et al., 2003; Losen et al., 2005) by reducing antibody-induced AChR internalization. Conversely, rapsyn upregulation has a detrimental effect in chronic experimental autoimmune myasthenia gravis (EAMG) where endplates are already substantially damaged. In chronic EAMG, increased rapsyn expression increases postsynaptic membrane turnover by anti-AChR antibodies (Martinez-Martinez et al., 2007).

In order to obtain further insight into the role of rapsyn in adult muscle, we studied the effect of down-regulation of rapsyn by RNA interference (RNAi). Previous studies using long double stand RNA based RNAi in vivo had shown that rapsyn is essential for induction of ectopic AChR clusters following injection of neuronal agrin in extrasynaptic muscle areas. Here, we used RNAi to study the effect of rapsyn on the already matured endplates (Kong et al., 2004). Adult muscles of rats were transfected by in vivo electroporation using the mammalian expression vector pSUPER that directs the synthesis of short hairpin RNA (shRNA) transcripts. The results suggest that rapsyn has a pivotal role for the postsynaptic folding and the maintenance of the AChR in the NMJ of adult muscle.

\section{Methods}

Silencing constructs. Four DNA sequences for transcription of SiRNA were selected according to Tuschl rules (Elbashir et al., 2001; Tuschl et al., 1999) from the coding DNA sequences of rapsyn conserved between rat (XM_215773) and mouse (J03962) (Table 1). The designed DNA oligonucleotides contained 19 nt sequences from rapsyn separated by a short spacer from the reverse complement of the same sequence. The corresponding pairs of DNA oligos were annealed and ligated into pSUPER digested with Bglll and Hindlll as previously described (Brummelkamp et al. 2002) and all constructs were sequenced. The efficiency of the different rapsyn silencing PSUPER was measured in vitro by co-transfecting the silencing pSuper constructs with a (mouse-) rapsyn-GFP expression vector (Marchand et al,, 2002) and the PSV-ß-Galactosidase expression vector (Promega, USA) in HEK 293 cells. The PSUPER empty vector was used as a negative control. HEK cells were cultured in DMEM with $10 \%$ heat-inactivated fetal bovine serum and transfected using the ProFection Mammalian Transfection system with calcium phosphate (Promega). Cells were fixated in $4 \%$ paraformaldehyde in PBS at different time points after transfection (24, 48 and 72 hours). The transfection efficiency was measured by $B$ galactosidase enzyme assay of cell extracts; the proportion of transfected cells was analyzed by in situ staining of the cells for B-galactosidase activity using X-gal. Fluo- 
rescence images of rapsyn-GFP were obtained with an Olympus $\mid X-71$ inverted microscope before fixation of cells. X-gal staining of fixated and cover slipped cells was photographed using an Olympus AX-70 microscope. Pictures were analyzed using the Imagel software (version 1.32 ; http://rsb.info.nih.gov/ij).

\section{Animals}

6-week-old female Lewis rats were obtained from the Department of Experimental Animal Services, University of Maastricht, The Netherlands, with permission of the Committee on Animal Welfare, according to Dutch governmental rules. For immunization, in vivo electroporation and electromyography measurements, the animals were anesthetized with $3 \%$ isoflurane in air, supplied over a cylindrical cap held over the head. The animals were euthanized by $\mathrm{CO}_{2} /$ air inhalation and subsequent cervical dislocation.

\section{Triple electroporation}

The different DNAs were prepared for electroporation with the Qiagen Maxiprep kit, according to the manufacturer's manual, and finally dissolved at a concentration of $2 \mu \mathrm{g} / \mu \mathrm{L}$ in $0.9 \% \mathrm{NaCl}$. The injection mix contained: $25 \mu \mathrm{g}$ of each silencing vector $S-1, S-2,5-3$ and $S-4$ and $50 \mu \mathrm{g}$ of pVax- $\beta$-galactosidase (Promega) in a total volume of $75 \mu \mathrm{L}$. For the contralateral muscle, $100 \mu \mathrm{g}$ empty PSUPER and $50 \mu \mathrm{g}$ of $\mathrm{pVax}-\beta$ galactosidase in a volume of $75 \mu \mathrm{L}$ were used. The electroporation in the tibialis anterior was performed with the same parameters as described previously (Losen et al., 2005) using the Electro Square Porator ECM 830 (BTX, San Diego, USA, for set-up see supplementary Fig. S1). This electroporation was repeated three times each other day under the same conditions.

\section{Induction of EAMG}

14 days after the first electroporation the rats were divided into two groups: half of the animals received no further treatment (control animals) the other half received intraperitoneal injections of the anti-AChR antibody mAb $35(20 \mathrm{pmol}$ per $100 \mathrm{~g}$ body weight; EAMG animals). After another 2 days, the rats were clinically scored, anesthetized for electromyography and sacrificed. Clinical scoring was performed by blinded investigators as previously described (Hoedemaekers et al., 1997a; Hoedemaekers et al., 1997b; Verschuuren et al., 1990). 


\section{Alpha-bungarotoxin treatment}

$\alpha-B T$ (Sigma, USA) was injected into the tibialis anterior muscle directly at a dose of 2-5 $\mu \mathrm{g}$ for 15 days, with injections every 48 hours. Sham-treated animals were injected with saline at the same time points. Each day, to check for a possible imminent, accumulating overdose of $\alpha-\mathrm{BT}$, the rats were clinically scored on a scale of + to +++ on the basis of the drooping of the lower lip and salivation; depending on the outcome of the score the next dose of $\alpha-B T$ was assessed to obtain a clinical effect of + or ++ . Using this treatment regimen, blocked AChRs are replaced at a rate of about $10 \%$ per day so that the degree of AChR block ranged from about $95-100 \%$ (on the day of $\alpha-B T$ injection) down to about $80 \% 48 \mathrm{~h}$ later (just before the next $\alpha$ BT injection) (Molenaar et al., 1991).

\section{Electromyography (EMG)}

Decrement of compound muscle action potential (CMAP) was measured simultaneously in both tibialis anterior muscles of 8 control and 9 EAMG rats. Stimulation of the peroneal nerve at the level of the knee and recording of the tibialis anterior muscles was performed as described before (Losen et al., 2005). To detect a decrement in the response, series of 8 supramaximal stimuli were given at $3 \mathrm{~Hz}$ with 0.2 ms stimulus duration. The test was considered positive for decrement when both the amplitude and the area of the negative peak of the CMAP showed a decrease of at least 10\% (Kimura, 2001). To demonstrate reproducibility, at least 3 recordings were made of all investigated muscles. During the measurements, skin temperature was kept between $35^{\circ} \mathrm{C}$ and $37^{\circ} \mathrm{C}$ by means of a heating pad. If no decrement was observed initially, repeated small doses of curare (tubocurarine chloride, Sigma, $0.5 \mu \mathrm{g}$ in EAMG animals; between $1.5 \mu \mathrm{g}$ up to $6 \mu \mathrm{g}$ in control animals) were injected intraperitoneally with intervals of 10 min until the test was positive. Up to $3 \mu \mathrm{g}$ of curare in EAMG animals and up to $16.5 \mu \mathrm{g}$ of curare in control animals were used (c.f. Janssen et al., 2008b; Seybold et al., 1976). The simultaneous recording of the CMAP during repetitive stimulation of both tibialis anterior muscles was used for measuring the lowest curare dose to produce a reproducible decremental response in each leg.

\section{Histochemical staining}

Isolated tibialis anterior muscles of several animals were frozen in melting isopentane. Cryosections of $10 \mu \mathrm{m}$ were stained for beta-galactosidase activity. The sections were warmed to $40-60^{\circ} \mathrm{C}$ for $3 \mathrm{~min}$, air dried for $1 \mathrm{~h}$, fixed in $2.0 \%$ glutaraldehyde in PBS for 20 min at room temperature, washed $3 x$ in PBS for 5 min and dried. Sections were then incubated at $37^{\circ} \mathrm{C}$ with a staining solution containing: $7.2 \mathrm{mM}$ $\mathrm{Na}_{2} \mathrm{HPO}_{4}, 2.8 \mathrm{mM} \mathrm{NaH}_{2} \mathrm{PO}_{4}, 150 \mathrm{mM} \mathrm{NaCl}, 1 \mathrm{mM} \mathrm{MgCl}, 3 \mathrm{mM} \mathrm{K}{ }_{3} \mathrm{Fe}(\mathrm{CN})_{6}, 3 \mathrm{mM}$ 
$\mathrm{K}_{4} \mathrm{Fe}(\mathrm{CN})_{6}$ and $0.3 \% \mathrm{X}$-Gal. When the staining appeared the sections where washed twice for 5 min in PBS and mounted in 70\% glycerol PBS.

Isolated tibialis anterior muscles of 3 control and 6 EAMG animals were analyzed by immunohistochemistry as described previously (Martinez-Martinez et al., 2007) with the following primary antibodies: mouse anti-rapsyn mAb 1234 (1/500; Sigma, USA) (Bloch and Froehner, 1987); rabbit anti-vesicular acetylcholine transporter (VAChT; 1/500; Sigma, USA); mouse anti-SV2 (directed against synaptic vesicles; $1 / 5000 ;$ DS Hybridoma Bank, USA) and rabbit-anti-sodium channel (III-IV) (1/500; Upstate, USA). The acetylcholine receptor was detected using Alexa 594conjugated $\alpha-B T$ (1/300; Molecular Probes, Leiden, The Netherlands). All antibodies were diluted in PBS with $2 \%$ BSA and incubated at room temperature for $1 \mathrm{~h}$. Washing steps were performed with PBS with $0.05 \%$ Triton-X100. Subsequently, the sections were incubated for $1 \mathrm{~h}$ at room temperature with the corresponding secondary antibodies: biotinylated donkey anti-mouse Ig (1/400; minimal cross-reaction with rat IgG; Jackson Immunoresearch, West Groove, USA); Alexa 350-conjugated goat anti-rabbit IgG (1/100; Molecular Probes); Alexa 488-conjugated goat antirabbit IgG (1/100 in PBSA; Molecular Probes) or donkey anti-rabbit IgG Alexa-594 (1/100; Molecular Probes). After washing, the biotinylated anti-mouse antibody was stained for $1 \mathrm{~h}$ at room temperature with Alexa 488-streptavidin (1/2000; Molecular Probes). Coverslips were mounted with $0.2 \mathrm{M}$ Tris $\mathrm{pH}=8$ with $80 \%(\mathrm{v} / \mathrm{v})$ glycerol.

\section{Quantitative immunofluorescence analysis}

The amounts of $A C h R$ and rapsyn at the neuromuscular junction were analyzed microscopically relative to the presynaptic vesicular acetylcholine transporter (VAChT) as previously described (Losen et al., 2005; Martinez-Martinez et al., 2007). The fluorescence intensities of $\alpha$-BT labeling correlates well with biochemical measurements of the $A C h R$, with the advantage that the histochemical analysis can be confined to the area of the NMJ without measuring extrajunctional AChR (Losen et al, 2005). Endplate areas were identified as regions of VAChT staining and the mean intensity of VAChT, rapsyn and AChR staining was measured in the corresponding area. The threshold intensity of VAChT staining for defining the margin of NMJ areas were automatically calculated for each picture. The ratios of AChR:VAChT and rapsyn:VAChT was calculated as a relative measure for the postsynaptic rapsyn and $A C h R$ concentration. The ratios of voltage gated sodium channel (VGSC) relative to the presynaptic synaptic vesicle protein 2 (SV-2) was calculated as a relative measure for the postsynaptic VGSC concentration. For each experiment, photos of more than 50 endplates per muscle were quantified. The expression of postsynaptic proteins was normalized with measurements in healthy control animals. Changes of postsynaptic protein expression relative to control levels are expressed as difference \pm standard error of the means. Where available, the corresponding reference 
CMAPTER 4

value from contralateral muscle of the same animal was used and the change of expression was calculated as difference \pm standard deviation of the relative differences.

\section{Two-photon laser scanning microscopy}

High power pictures of endplates were taken using a two-photon laser scanning microscope setup as previously described (Martinez-Martinez et al., 2007). For projection of the images the ImageJ software was used.

\section{Electron microscopy}

Electron micrographs were taken from endplates of the tibialis anterior muscles of 6 control rats and 3 EAMG rats with unilateral- rapsyn silencing treatment. For the $\alpha-$ BT treatment experiment electron micrographs were taken from endplates of the tibialis anterior muscles of 4 sham-treated rats and 3 intramuscular $\alpha$-BT-treated rats. Anesthetized rats were transcardially perfused as previously described (Losen et al., 2005; Martinez-Martinez et al., 2007). Ultra-thin sections were viewed with Philips CM 100 electron microscope. At least five endplate regions were photographed from each muscle. Pictures were scanned for morphometric analysis using the Imagel software as described previously (Engel et al., 1976a; Engel et al., 1976b; Losen et al., 2005; Martinez-Martinez et al., 2007).

\section{Statistics}

GraphPad Prism 4 was used to perform statistical analyses. Comparison between normally distributed values was performed using a paired or unpaired t-test, wherever appropriate. A two-sided probability value $<0.05$ was considered significant. Values are expressed as means \pm standard deviation (SD) unless stated otherwise.

\section{Results}

Rapsyn ShRNA reduced rapsyn and AChR protein levels in adult rat muscles

In order to knock-down the expression of rapsyn in the adult muscle, we designed 4 short hairpin oligonucleotides (S1-S4, Table 1) which were cloned into the pSUPER expression vector and initially tested in vitro by co-transfection with rapsyn-GFP in HEK 293 cells. Following transfection, all 4 pSUPER constructs efficiently reduced the levels of rapsyn-GFP (between $84 \%$ and $98 \%$ ) expression compared to rapsynGFP co-transfected with the empty pSUPER vector; the combination of all silencers 
showed a reduction of rapsyn-GFP levels of $88 \%$ ( $\pm 9.22 \%$, SEM; $p<0.005$, unpaired t-test) (Supplementary Fig. S2).

Subsequently we used electroporation to transfect the shRNA expression vectors into the rat muscles. We pooled equal amounts of shRNA expression vectors $S 1, S 2, S 3$ and $\$ 4$, in order to maintain rapsyn silencing while reducing concentrations of each individual plasmid and thereby the contribution of off-target effects (Blow, 2008; Brown and Samarsky, 2006; Hsieh et al., 2004). Because this transfection procedure can lead to transient tissue damage and inflammation (unpublished observations), we used the contralateral muscles as a control. These were injected with a control vector and electroporated using the same protocol. On average, a single electroporation (cf. Losen et al., 2005; Roorda et al., 2005) was not sufficient to reduce rapsyn protein levels at the neuromuscular junction relative to presynaptic VAChT levels at any time point analyzed (2, 4 and 6 weeks after; data not shown). However, a few endplates $(<1 \%)$ from tibialis anterior muscles single-electroporated with silencing vectors showed decreased amounts of rapsyn (Supplementary Fig. S3). Endplates of rat tibialis anterior muscle electroporated with pSUPER empty vector never showed a decrease in rapsyn (not shown) at any time point analyzed, as expected from experiments performed by Kong et al. (2004) with similar vectors. To improve the transfection efficiency we tested repeated electroporations (triple electroporation with $48 \mathrm{~h}$ intervais): 8 animals were electroporated in the left tibialis anterior muscle with a combination of $\mathrm{pVax}-\beta$-galactosidase reporter vector and PSUPER silencing vectors; the contralateral muscles were transfected with $p V a x-\beta-$ galactosidase reporter vector and pSUPER empty vector. Two weeks after transfection, $B$-gal was present in the majority of muscle cells $1>90 \%$ of the fibers in the muscle belly, Fig. 1); albeit with widely varying expression levels.

The effect of shRNAs on rapsyn and AChR protein levels was examined in 5 healthy animals and compared to 6 myasthenic rats. Two weeks after the first electroporation and 48 hours after the mAb 35 injection for the myasthenic animals the tibialis anterior muscles were isolated. Cryosections from these animals were triplestained for rapsyn, AChR and for the presynaptic vesicular acetylcholine transporter (VAChT). We used two-photon microscopy to examine the NMJs in detail. Representative endplates of control, silenced and EAMG muscles are shown in Figure 2A. Silenced endplates appeared to have reduced amounts of rapsyn and also of AChR compared to endplates in control muscles, while the presynaptic staining of VAChT was unaffected. In EAMG muscles, the AChR and the rapsyn levels in tibialis anterior muscles were strongly reduced. The quantification of immunohistochemical staining of more than 1000 endplates in tibialis anterior muscles of healthy rats confirmed a reduction in the relative concentrations of rapsyn (by $33.2 \% \pm 14.5 \%, p=0.016$, paired t-test) and of $A C h R$ (by $33.8 \% \pm 13.9 \%, p=0.011$, paired $t$-test) as a result of rapsyn-silencing (Fig. $2 B, C$ ). This effect was in fact similar to the result of $m A b 35$ treatment, where rapsyn was reduced by $62.6 \%( \pm 11.6 \%, p<0.001$ unpaired t-test) 
and the AChR was reduced by $25.5 \%$ ( $\pm 22.7 \%, p=0.062$ unpaired t-test $)$ compared to control muscles. The reduction of rapsyn and receptor in rapsyn-silenced muscles was not homogeneous. The distribution of $A C h R$ and rapsyn intensities in stained endplates (Figure 2D, E) show that some fibers lost more than $50 \%$ of rapsyn, while others were unaffected.

\section{Reduced rapsyn expression impairs neuromuscular transmission}

To study the effect of unilateral rapsyn-silencing on neuromuscular transmission we measured the compound muscle action potentials (CMAP; using repetitive nerve stimulation at $3 \mathrm{~Hz}$ ) in tibialis anterior muscles of 8 healthy (control) and 9 myasthenic rats. The safety factor of neuromuscular transmission was challenged by repeated intraperitoneal injections of the $A C h R$ antagonist curare until a decrement in the response of the CMAP was observed. The stimulations and CMAP measurements were performed bilaterally and simultaneously in the tibialis anterior muscles in order to detect differences between the non-silenced and the rapsyn-silenced leg. The resistance against curare was used as an indirect, albeit non-linear, measure for the safety factor of neuromuscular transmission. A representative examples of CMAP measurements of control, silenced and EAMG animals are shown in Figure $3 \mathrm{~A}-\mathrm{C})$, and the results of all animals are summarized in Figure 3D. In control muscles a cumulative dose of $11.4 \mu \mathrm{g}( \pm 3.1 \mu \mathrm{g})$ of curare was required to induce a reproducible decremental response of the CMAP (>10\%). By contrast, the contralateral rapsyn-silenced muscles were significantly less resistant against curare $(8.8 \mu \mathrm{g} \pm 3.1$ $\mu \mathrm{g}, p=0.006$ paired t-test). Since rapsyn loss is also observed in experimental autoimmune myasthenia gravis (EAMG) models (cf. Losen et al., 2005; MartinezMartinez et al., 2007) we performed identical electromyography measurements in a passive transfer model of MG with the anti-AChR mAb 35. EAMG was induced in 9 rats ( 12 days after sham electroporation of the tibialis anterior muscles with control plasmids). Within 48 hours all animals had clear clinical signs of EAMG (score of ++ in each animal). Decrementing responses could be demonstrated without curare injections (4 out of 9 animals) while in the other animals very low curare doses were sufficient to induce decrement (between 0.25 and $2.5 \mu \mathrm{g}$; on average $0.6 \mu \mathrm{g} \pm 0.6$ $\mu \mathrm{g}, \mathrm{n}=9, \mathbf{p}<0.001$ compared to non-silenced control muscles). On the basis of these measurements, the neuromuscular transmission defect caused by mAb 35 alone was significantly more severe than caused by rapsyn-silencing $(p<0.001)$.

\section{Rapsyn silencing causes increased folding of the postsynaptic membrane}

Since the reduction of the safety factor of neuromuscular transmission after rapsynsilencing and $\mathrm{mAb} 35$ did not correlate to synaptic AChR expression, we speculated that ultrastructural differences were the underlying cause for the observed effects. 
Therefore, we performed electron microscopic observations and morphometric analysis on tibialis anterior muscles of 3 EAMG and 6 control rats two weeks after unilateral rapsyn-silencing.

Indeed, the silencing of rapsyn altered the structure of the NMJ (Fig 4B). There was an increase in the average length of the postsynaptic membrane compared to that of control muscles (Fig. 4A). Quantitative morphometric analysis confirmed a significantly increased length of the postsynaptic membrane relative to the presynaptic membrane (folding index; Fig. 4D). The folding index showed considerable variation in the tibialis anterior muscle, which is possibly due to differential specialization of the postsynaptic membrane in type I and type II fibers (Pachter and Eberstein, 1984; Pachter and Eberstein, 1986). The area of postsynaptic folds was increased and the nerve terminal size was slightly, but significantly decreased in rapsyn-silenced muscles (Table $2 ; p<0.05$ ). Although it appeared that some postsynaptic folds were not direct adjacent to nerve terminals (eg. in Fig. $4 \mathrm{~B}$ ), analysis of serial sections of endplates showed that such areas were also connected to over or underlying nerve boutons (supplementary Fig. S4). As expected, endplates in the EAMG muscles showed the typical reduction of the folding index (Fig. 4C) compared to control muscles. Interestingly, also a reduction of the nerve terminal bouton size was observed in rapsyn-silenced muscles, suggesting the possibility that rapsyn is involved in retrograde signaling from the muscle to the nerve.

Rapsyn shRNA increased voltage gated sodium channel protein levels in adult rat muscles

In addition to the AChRs the postsynaptic membrane contains a high density of voltage-gated sodium channels (VGSCS). VGSCs have a postsynaptic localization at the troughs of folds where they are 10 times as concentrated as in the membrane far from the NMJs (Flucher and Daniels, 1989). To study how the silencing of rapsyn affected the concentration of VGSCs in the increased folding of the postsynaptic membrane, we performed quantitative immunofluorescence analysis on the muscle fibers (as described above for rapsyn and $A C h R$ ). Cryosections of the isolated tibialis anterior muscles were double-stained for VGSCS and the presynaptic marker SV-2. Endplates in rapsyn-silenced tibialis anterior muscles showed an increase in the concentration of VGSC compared to control muscles (Fig. 5A). The quantification of immunohistochemical staining of endplates in rapsyn-silenced tibialis anterior muscles confirmed an increase in the relative concentrations of VGSCs (by $26.1 \% \pm 24.2 \%$, $p=0.032$, paired t-test) compared to control endplates. In EAMG tibialis anterior muscles VGSCs were reduced (by $27.9 \% \pm 7.8 \%, p<0.001$ unpaired t-test) compared to control muscles (Fig. 5C), In conclusion, the VGSC levels correlated well with the folding index and folding area of the postsynaptic membrane. 
CHAFTER 4

Bungarotoxin treatment increases both the presynaptic and the postsynaptic membrane length

The effect of rapsyn-silencing on endplate structure could have been due to an off target effect, a direct effect of rapsyn loss, or to an indirect effect caused by reduction of the number of AChRs per endplate which follows rapsyn silencing. In order to test the latter possibility, tibialis muscles were directly injected with repeated doses of $\alpha$-BT for a period of 15 days to block the AChR activity. To study how this procedure affected the ultrastructure of the neuromuscular junctions, we performed electron microscopic observations and morphometric analysis in 4 salinetreated and $3 \alpha-B T$-treated animals. Compared with saline treatment, the endplates showed morphological abnormalities after the treatment with $\alpha$-BT (Fig. 6). The most remarkable abnormality was the significant increase in length of the preas well as the postsynaptic membrane ( $p<0.05$; unpaired t-test) (Table 3 ). As such, there is an increased contact area between the pre- and the postsynaptic membrane, which is observed in 99 out of 150 regions (Fig. 6B, C). Because of the increase of both the presynaptic and the postsynaptic membrane length, the ratio of postsynaptic to presynaptic membrane length was not significantly different $(p=0.81$, unpaired t-test; Table 3 ). A change of the nerve bouton size was not observed under these conditions. In conclusion, the postsynaptic changes observed after $\alpha-B T$ treatment were very similar to those observed after rapsyn silencing, while the presynaptic alterations were not identical.

\section{Discussion}

In this study we analyzed the effect of reduced rapsyn expression levels in the adult neuromuscular junction by shRNA. Reduced rapsyn levels led to reduction of AChR and a moderate impairment of the safety factor of neuromuscular transmission. Conversely, the VGSC, which are located in the troughs of the postsynaptic membrane, were increased in silenced muscles. Surprisingly, postsynaptic membrane folding was markedly increased. Together with the increase in VGSC levels this probably represents a compensatory mechanism to protect neuromuscular transmission since the density of sodium channels in the postsynaptic folds determine the firing threshold and safety factor of the neuromuscular transmission (Wood and Slater, 1997).

For the interpretation of the results it is important to consider off-target effects of the shRNA electroporation procedure (Jackson et al., 2003). Off target effects can be caused by the transfection method, double-stranded RNA-induced inflammation and RISC-dependant effects. As a control for the transfection method we electroporated the contralateral tibialis anterior muscles in each animal with a control plas- 
mid and used these muscles as a reference in the experiments. Because of multiple injections and electroporation, muscles were subjected to transient damage and inflammation, and were thus not completely normal. Because plasmid DNA and not dsRNA was used for the transfection, activation of the interferon response via Toll like receptor 3 (Reynolds et al., 2006; Sledz et al., 2003) was less likely to be involved. In order to reduce the chance of possible sequence dependant off-target responses we used the minimal effective amount of 4 different shRNA expression plasmids, which all target rapsyn, but not likely the same potential off-target protein. Moreover, compared to the results using shRNA against rapsyn, we found similar structural changes of the postsynaptic membrane when we blocked the AChR with $\alpha-B T$. Since rapsyn and AChR activity are closely coupled, this effect is not likely due to off-target effects of the shRNAs.

The finding that rapsyn negatively influences postsynaptic folding may seem contradictory to the data obtained with the rapsyn knock-out model (Gautam et al., 1995) and findings in biopsies of congenital myasthenic syndromes with rapsyn mutations. Indeed, mutations within the RAPSN gene have been shown to underlie a high proportion of AChR deficiency syndromes (Burke et al., 2003; Dunne and Maselli, 2003; loos et al., 2004; Maselli et al., 2003a; Muller et al., 2003; Ohno et al., 2002; Ohno et al., 2003). Endplates of patients with the N88K rapsyn mutation contain a reduced number of postsynaptic folds (Ohno et al., 2002; Ohno et al., 2003), which could lead to a reduction of the safety factor of the neuromuscular transmission (Ruff and Lennon, 1998; Ruff and Lennon, 2008). However, the N88K mutation does not only lead to a very low rapsyn expression, but also impairs its selfaggregation and AChR-clustering (Cossins et al., 2006). Conversely, in our experiments, rapsyn was silenced in adult rats and the rapsyn protein levels were reduced, without affecting the intrinsic properties of the protein. The distinct morphology of rapsyn-silenced endplates and the mild impairment of the safety factor of neuromuscular transmission in rapsyn-silenced muscles suggest that the reduction of rapsyn expression is not the primary cause of the disease in CMS associated with N88K rapsyn mutations, which would rather be caused by the alteration of rapsyn function. In rapsyn knock-out mice, already the initial steps of postsynaptic differentiation are blocked, so the lack of postsynaptic folding in the animals is likely due to rapsyn-dependent steps of early subsynaptic gene expression that is also affected in agrin and MuSK knock-out mice (Gautam et al., 1999). It will be interesting to study the ultrastructure of heterozygous rapsyn ${ }^{+/}$mice and in CMS patients with the homozygous RAPSN-promoter mutation $-38 \mathrm{~A} / \mathrm{G}$ which reduces rapsyn expression (Ohno et al., 2003).

In experimental autoimmune MG, rapsyn is lost concomitantly with the AChR (Losen et al., 2005; Martinez-Martinez et al., 2007). Since reduced rapsyn expression can possibly lead to a neuromuscular transmission defect by itself, we addressed the issue of the role of rapsyn reduction in autoimmune MG. Because AChR 
CHAPTEn

expression levels were similarly reduced in EAMG and silenced muscles, we could compare the respective impacts of reduced postsynaptic membrane folding and membrane attack complex on neuromuscular transmission. For this purpose, electromyography measurements were performed in the presence of increasing doses of curare to evaluate the neuromuscular safety factor. Despite similarly reduced synaptic rapsyn and AChR levels, the 'safety factor' expressed as the resistance to curare, in EAMG muscles was much lower than in rapsyn-silenced muscles. These data confirm previous observations (Ruff and Lennon, 1998; Ruff and Lennon, 2008) suggesting that not only AChR loss, but also the loss of postsynaptic folds with VGSC and/or the presence of membrane attack complex strongly worsened the neuromuscular transmission defects in EAMG. The mechanism of pastsynaptic folding reduction in EAMG is a concerted action of cross-linking antibodies and complement activation (Losen et al., 2008b). Although complement-mediated membrane attack can contribute to the severe neuromuscular transmission defect in EAMG muscles (as a result of its depolarizing effect), it is not sufficient to induce decrement by itself. We have previously shown that increased rapsyn expression prevents AChR modulation and efficiently protects synapses against complement activation (Losen et al., 2005). Therefore, it can be argued that increased postsynaptic folding in rapsyn-silenced muscles may serve to compensate for the loss of rapsyn-AChR clusters at the postsynaptic membrane, which would otherwise lead to a great reduction of the safety factor, as we presently observed in EAMG muscle. This is in line with previous observations that the complexity of postsynaptic folding of the neuromuscular junction can increase the safety factor (Ruff and Lennon, 1998; Wood and Slater, 1997; Wood and Slater, 2001). In this respect, it is interesting to note that the human neuromuscular junction has used the same strategy to compensate for low AChR expression compared to other species, which in turn have less complex postsynaptic folding (Wood and Slater, 2001). It seems possible, that in MG, because of the reduction of the levels of AChR and rapsyn, there is also a tendency for an increase in the level of endplate VGSC and of the extent of postsynaptic folding, but that this is counteracted by autoimmune-induced damage to the endplate. Such a regulation seems likely, since also rapsyn and AChR mRNA expression are upregulated in EAMG to compensate for rapsyn and AChR loss (Asher et al., 1993).

So far, very little is known about the mechanisms that regulate postsynaptic folding. The increase of postsynaptic folding is possibly mediated via the balance between acetylcholine and agrin, which have been identified as key factors in synapse differentiation. Since agrin is thought to counteract the ACh-dependent dispersal of AChR clusters in embryonic muscle (Lin et al., 2005; Misgeld et al., 2005), we investigated the possibility that postsynaptic membrane folding was regulated via $A C h R$ activation by ACh. Alternatively, one could postulate that the protein levels of rapsyn and $A C h R$ could directly determine membrane folding, independently of $A C h$, electrical activity or ensuing changes of intracellular concentrations of $\mathrm{Ca}^{2+}$ and 
$\mathrm{Na}^{+}$. To answer this question, $\alpha-\mathrm{BT}$ was directly injected into the tibialis muscles of rats in order to block AChR activity. Subsequently, we analyzed the effect of AChR blocking by electron microscopy. This treatment also led to a marked increase in postsynaptic membrane area and length, suggesting that AChR activity is indeed correlated to postsynaptic membrane structure. Because the contact area between the muscle and the nerve boutons was also increased, the folding index was not changed. The different presynaptic manifestations of rapsyn silencing versus $\alpha$-BTtreatment might reflect the degree of AChR blocking.

Interestingly, recent studies showed that $\alpha-B T$ does not only block the AChR, but also induces rapid disaggregation of $A C h R /$ rapsyn clusters, without affecting synaptic AChR protein levels (Brockhausen et al., 2008). Therefore, it is possible, that also the $\alpha$-BT-induced increase of postsynaptic membrane folding is mediated via rapsyn. Since rapsyn concentration and AChR activity are closely correlated, we can not conclude which of these two proteins are responsible for the observed morphological changes at the NMJ.

of course, these results do not exclude the possibility that rapsyn expression can also modulate synapse morphology via other molecules. It has been described that in addition to its role in AChR anchoring to the cytoskeleton, rapsyn specifically interacts with beta-catenin, which is involved in NMJ presynaptic differentiation and function (Li et al., 2008; Zhang et al., 2007). Interestingly, we also found presynaptic changes in rapsyn-silenced muscles. Furthermore, rapsyn interaction with calpain, a calcium-dependent protease, has been shown to stabilize AChR clusters at the NMJ (Chen et al., 2007). Unfortunately, nothing is known yet about the effect of these interactions at the ultrastructural level and the molecular mechanism by which rapsyn exerts its effect on pre- and postsynaptic differentiation will require further investigation. The described results allow the conclusion that agrin does not increase postsynaptic folding via increased rapsyn/AChR interaction.

Our results are compatible with the hypothesis that ACh negatively and agrin positively regulate synapse differentiation (Lin et al., 2005; Misgeld et al., 2005). As an extension to this hypothesis, we propose that $A C h$ and agrin not only affect AChR-rapsyn clustering, but also VGSC accumulation and membrane folding. Interestingly, neuropathology has already provided us with examples where increased synaptic complexity is found. In some cases of Lambert-Eaton myasthenic syndrome (LEMS) increased folding of the postsynaptic membrane (Santa et al., 1972) or increased nerve muscle contact (Hesselmans et al, 1992) occurs. LEMS is an autoimmune disease in which antibodies interfere with presynaptic calcium channel function causing a reduction of calcium-dependent ACh release (Santa et al., 1972). Limb immobilization, which causes a decrease of neuronal activity, provides another example of increased NMJ complexity. The main features of these NMJs are terminal sprouting and ultrastructural remodeling sometimes corresponding to large expanses of postsynaptic folds without associated nerve terminals (Pachter and 
Eberstein, 1984; Pachter and Eberstein, 1986). These, and other examples of increased complexity (Gomez et al., 1996; Maselli et al., 2003b; Sroka et al., 1975) might be explained by the considerable ability of the NMJ to respond to defects in some of its components by compensatory enhancement of others.

Pre- and postsynaptic components change during development and may show plasticity in response to injury or disease. It has been suggested that the structure and molecular organization of the postsynaptic apparatus takes an excess of the released transmitter from the nerve, helping to ensure that every nerve impulse normally triggers a muscle action potential with a very small chance of failure. The concept of safety factor for neuromuscular transmission describes this excess (Martin, 1994; Wood and Slater, 1995; Wood and Slater, 1997; Wood and Slater, 2001). It is of interest that a modest reduction of rapsyn expression already causes substantial changes, showing that the amount of rapsyn is critically related to the AChR levels and to the structure of the endplate. In all conditions, analyzed rapsyn and AChR levels were strongly correlated. This is in line with previous observations performed at sites undergoing synapse elimination, where rapsyn loss was parallel to AChR loss (Culican et al., 1998). The present study suggests that rapsyn determines AChR density at the adult NMJ, and supports the hypothesis that functional AChR and rapsyn clusters negatively regulate postsynaptic folding. Finally, the results indicate a very dynamic subsynaptic machinery in adult NMJs that can rapidly extend postsynaptic folds or produce new ones.

\section{Acknowledgements}

We would like to thank Jean Cartaud from the Institut Jacques Monod for the rapsyn-GFP construct and Reuven Agami from the Netherlands Cancer Institute for providing the pSUPER vector and advice for cloning the silencing constructs. PM-M was supported by grants from the Prinses Beatrix Fonds (project: MAR03-0115) and L'Association Française contre les Myopathies. We would like to thank Robert van Os, Phillip Becker and Joost van den Broeck for their help with the quantitative morphometry analysis and Eline van der Esch for her excellent technical assistance.

\section{References}

Asher, O., Kues, W.A., Witzemann, V., Tzartos, S.J., Fuchs, S., Souroujon, M.C., 1993. Increased gene expression of acetylcholine receptor and myogenic factors in passively transferred experimental autoimmune myasthenia gravis. 3 immunol 151, 6442-6450

Bezakova, G., Rabben, I., Sefland, I., Fumagalli, G., Lomo, T., 2001. Neural agrin controls acetylcholine receptor stability in skeletal muscle fibers. Proc Natl Acad Sci U S A 98, 9924-9929.

Bloch, R.J., Froehner, S.C., 1987. The relationship of the postsynaptic 43K protein to acetylcholine receptors in receptor clusters isolated from cultured rat myotubes. J Cell Biol 104, 645-654.

Blow, N., 2008. RNAi technologies: a screen whose time has arrived. Nature Methods 5, 361-366. 
Brockhausen, J., Cole, R.N., Gervasio, O.L., Ngo, S.T., Noakes, P.G., Phillips, W.D., 2008. Neural agrin increases postsynaptic $A C h$ receptor packing by elevating rapsyn protein at the mouse neuromuscular synapse. Dev Neurobiol 68, 1153-1169.

Brown, K., Samarsky, D., 2006. RNAi off-targeting: Light at the end of the tunnel. Journal of RNAi and Gene Silencing 2, 175-177.

Brummelkamp, T.R., Bernards, R., Agami, R., 2002. A system for stable expression of short interfering RNAs in mammalian cells. Science 296, 550-553.

Burke, G., Cossins, J., Maxwell, S., Owens, G., Vincent, A., Robb, S., Nicolle, M., Hilton-Jones, D., NewsomDavis, J., Palace, J., Beeson, D., 2003. Rapsyn mutations in hereditary myasthenia: distinct early- and late-onset phenotypes. Neurology 61, 826-828.

Chen, F., Qian, L., Yang, Z.H., Huang, Y., Ngo, S.T., Ruan, N.J., Wang, J., Schneider, C., Noakes, P.G., Ding, Y.Q., Mei, L., Luo, Z.G., 2007. Rapsyn interaction with calpain stabilizes AChR clusters at the neuromuscular junction. Neuron 55, 247-260.

Cossins, J., Burke, G., Maxwell, S., Spearman, H., Man, S., Kuks, J., Vincent, A., Palace, J., Fuhrer, C., Beeson, D., 2006. Diverse molecular mechanisms involved in AChR deficiency due to rapsyn mutations. Brain 129, 2773-2783.

Culican, S.M., Nelson, C.C., Lichtman, J.W., 1998. Axon withdrawal during synapse elimination at the neuromuscular junction is accompanied by disassembly of the postsynaptic specialization and withdrawal of Schwann cell processes. J Neurosci 18, 4953-4965.

De Baets, M., Stassen, M., Losen, M., Zhang, X., Machiels, B., 2003. Immunoregulation in experimental autoimmune myasthenia gravis-about $T$ cells, antibodies, and endplates. Ann $N Y$ Acad Sci 998 , 308-317.

DeChiara, T.M., Bowen, D.C., Valenzuela, D.M., Simmons, M.V., Poueymirou, W.T., Thomas, S., Kinetz, E., Compton, D.L., Rojas, E., Park, J.S., Smith, C., DiStefano, P.S., Glass, D.J., Burden, S.J., Yancopoulos, G.D., 1996. The receptor tyrosine kinase MuSK is required for neuromuscular junction formation in vivo. Cell $85,501-512$

Dunne, V., Maselli, R.A., 2003. Identification of pathogenic mutations in the human rapsyn gene. J Hum Genet 48, 204-207.

Elbashir, S.M., Harborth, J., Lendeckel, W., Yalcin, A., Weber, K., Tuschl, T., 2001. Duplexes of 21nucleotide RNAs mediate RNA interference in cultured mammalian cells. Nature 4.11, 494-498.

Engel, A.G., Sine, S.M., 2005. Current understanding of congenital myasthenic syndromes. Curr Opin Pharmacol 5, 308-321.

Engel, A.G., Tsujihata, M., Lambert, E.H., Lindstron, J.M., Lennon, V.A., 1976a. Experimental autoimmune myasthenia gravis: a sequential and quantitative study of the neuromuscular junction ultrastructure and electrophysiologic correlations. J Neuropathol Exp Neurol 35, 569-587.

Engel, A.G., Tsujihata, M., Lindstrom, J.M., Lennon, V.A., 1976b. The motor end plate in myasthenia gravis and in experimental autoimmune myasthenia gravis. A quantitative ultrastructural study. Ann $N Y$ Acad Sci 274, 60-79.

Flucher, B.E., Daniels, M.P., 1989. Distribution of $\mathrm{Na}+$ channels and ankyrin in neuromuscular junctions is complementary to that of acetylcholine receptors and the $43 \mathrm{kd}$ protein. Neuron 3, 163-175.

Gautam, M., DeCliara, T.M., Glass, D.J., Yancopoulo5, G.D., Sanes, J.R., 1999. Distinct phenotypes of mutant mice lacking agrin, MuSK, or rapsyn. Brain Res Dev Brain Res 114, 171-178.

Gautam, M., Noakes, P.G., Moscoso, L., Rupp, F., Scheller, R.H., Merlie, J.P., Sanes, J.R., 1996. Defective neuromuscular synaptogenesis in agrin-deficient mutant mice. Cell 85, 525-535.

Gautam, M., Noakes, P.G., Mudd, J., Nichol, M., Chu, G.C., Sanes, J.R., Merlie, J.P., 1995. Failure of postsynaptic specialization to develop at neuromuscular junctions of rapsyn-deficlent mice. Nature 377 , 232-236.

Gervasio, O.L., Armson, P.F., Phillips, W.D., 2007. Developmental increase in the amount of rapsyn per acetylcholine receptor promotes postsynaptic receptor packing and stability. Dev Biol 305, 262-275.

Gervasio, O.L., Phillips, W.D., 2005. Increased ratio of rapsyn to $\mathrm{ACh}$ receptor stabilizes postsynaptic receptors at the mouse neuromuscular synapse. J Physiol 562, 673-685. 
Gomez, C.M., Maselli, R., Gammack, J., Lasalde, J., Tamamizu, S., Cornblath, D.R., Lehar, M., McNamee, M., Kuncl, R.W., 1996. A beta-subunit mutation in the acetylcholine receptor channel gate causes severe slow-channel syndrome. Ann Neurol 39, 712-723.

Hantai, D., Richard, P., Koenig, J., Eymard, B., 2004. Congenital myasthenic syndromes. Curr Opin Neurol $17,539-551$.

Hesselmans, L.F., Jennekens, F.G., Kartman, J., Wokke, J.H., de Visser, M., Klaver-Krol, E.G., DeBaets, M., Spaans, F., Veldman, H., 1992. Secondary changes of the motor endplate in Lambert-Eaton myasthenic syndrome: a quantitative study. Acta Neuropathol 83, 202-206.

Hoedemaekers, A., Bessereau, J.L., Graus, Y., Guyon, T., Changeux, J.P., Berrih-Aknin, S., van Breda Vriesman, P., De Baets, M.H., 1998. Role of the target organ in determining susceptibility to experimental autoimmune myasthenia gravis, J Neuroimmunol 89, 131-141.

Hoedemaekers, A., Graus, Y., van Breda Vriesman, P., de Baets, M., 1997a. Age- and sex-related resistance to chronic experimental autoimmune myasthenia gravis (EAMG) in Brown Norway rats. Clin Exp Immunol 107, 189-197.

Hoedemaekers, A., Verschuuren, J.J., Spaans, Fu, Graus, Y.F., Riemersma, S., van Breda Vriesman, P.J., De Baets, M.H., 1997b. Age-related susceptibility to experimental autoimmune myasthenia gravis: immunological and electrophysiological aspects. Muscle Nerve 20, 1091-1101.

Hsieh, A.C., Bo, R., Manola, J., Vazquez, F., Bare, O., Khvorova, A., Scaringe, S., Sellers, W.R., 2004. A library of siRNA duplexes targeting the phosphoinositide 3-kinase pathway: determinants of gene silencing for use in cell-based screens. Nucleic Acids Res 32, 893-901.

loos, C., Barois, A., Richard, P., Eymard, B., Hantai, D., Estournet-Mathiaud, B., 2004. Congenital myasthenic syndrome due to rapsyn deficiency: three cases with arthrogryposis and bulbar symptoms. Neuropediatrics 35, 246-249.

Jackson, A.L., Bartz, S.R., Schelter, J., Kobayashi, S.V., Burchard, J., Mao, M., Li, B., Cavet, G., Linsley, P.S., 2003. Expression profiling reveals off-target gene regulation by RNAi. Nat Biotechnol 21, 635-637.

Janssen, S.P., Phernambucq, M., Martinez-Martinez, P., De Baets, M.H., Losen, M., 2008. Immunosuppression of experimental autoimmune myasthenia gravis by mycophenalate mofetll. J Neurolmmunol 201-202, 111-120.

Kim, N., Stiegler, A.L., Cameron, T.O., Hallack, P.T., Gomez, A.M., Huang, J.H., Hubbard, S.R., Dustin, M.L., Burden, S.J., 2008. Lrp4 is a receptor for Agrin and forms a complex with MuSK. Cell 135, 334-342.

Kimura, J., 2001. Electrodiagnosis in diseases of nerve and muscle: principles and practice. Oxford University Press, Oxford, pp. 1024.

Kong, X.C., Barzaghi, P., Ruegg, M.A., 2004. Inhibition of synapse assembly in mammalian muscle in vivo by RNA interference. EMBO Rep 5, 183-188.

Li, X.M., Dong, X.P., Luo, S.W., Zhang, B., Lee, D.H., Ting, A.K., Neiswender, H., Kim, C.H., CarpenterHyland, E., Gao, T.M., Xiong, W.C., Mei, L., 2008. Retrograde regulation of motoneuron differentiation by muscle beta-catenin. Nat Neurosci 11, 262-268.

Lin, W., Dominguez, B., Yang, J., Aryal, P., Brandon, E.P., Gage, F.H., Lee, K.F., 2005. Neurotransmitter acetylcholine negatively regulates neuromuscular synapse formation by a Cdk5-dependent mechanism. Neuron 46, 569-579.

Losen, M., Martinez-Martinez, P., Phernambucq, M., Schuurman, J., Parren, P.W., MH, D.E.B., 2008. Treatment of myasthenia gravis by preventing acetylcholine receptor modulation. Ann N $Y$ Acad Scl 1132, 174-179.

Losen, M., Stassen, M.H., Martinez-Martinez, P., Machiels, B.M., Duimel, H., Frederik, P., Velidman, H., Wokke, J.H., Spaans, F, Vincent, A., De Baets, M.H., 2005. Increased expression of rapsyn in muscles prevents acetylcholine receptor loss in experimental autoimmune myasthenia gravis. Brain 128 , 2327-2337.

Marchand, S., Devillers-Thiery, A., Pons, S., Changeux, J.P., Cartaud, J., 2002. Rapsyn escorts the nicotinic acetylcholine receptor along the exocytic pathway via association with lipid rafts. I Neurosci 22, 8891-8901. 
Martin, A.R., 1994. Amplification of Neuromuscular-Transmission by Postjunctional Folds. Proceedings of the Royal Society of London Series B-Biological Sciences 258, 321-326.

Martinez-Martinez, P., Losen, M., Duimel, H., Frederik, P., Spaans, F., Molenaar, P., Vincent, A., De Baets, M.H., 2007. Overexpression of rapsyn in rat muscle increases acetylchaline receptor levels in chronic experimental autoimmune myasthenia gravis. Am J Pathol 170, 644-657.

Maselli, R.A., Dunne, V., Pascual-Pascual, S.I., Bowe, C., Agius, M., Frank, R., Wollmann, R.L., 2003 a. Rapsyn mutations in myasthenic syndrome due to impaired receptor clustering. Muscle Nerve 28 , 293-301.

Maselli, R.A., Wan, J., Dunne, V., Graves, M., Baloh, R.W., Wollmann, R.L., Jen, J., 2003b. Presynaptic fallure of neuromuscular transmission and synaptic remodeling in EA2. Neurology 61, 1743-1748.

Misgeld, T., Kummer, T.T., Lichtman, J.W., Sanes, J.R., 2005. Agrin promotes synaptic differentiation by counteracting an inhibitory effect of neurotransmitter. Proc Natl Acad Sci U S A 102, 11088-11093.

Molenaar, P.C., Oen, B.S., Plomp, J.J., Van Kempen, G.T., Jennekens, F.G., Hesselmans, L.F., 1991. A nonimmunogenic myasthenia gravis model and its application in a study of transsynaptic regulation at the neuromuscular junction. Eur J Pharmacol 196, 93-101.

Muller, J.S., Mildner, G., Muller-Felber, W., Schara, U., Krampfl, K., Petersen, B., Petrova, S., Stucka, R., Mortier, W., Bufler, J., Kurlemann, G., Huebner, A., Merlini, L., Lochmuller, H., Abicht, A., 2003. Rapsyn N88K is a frequent cause of congenital myasthenic syndromes in European patients. Neurology $60,1805-1810$.

Nitkin, R.M., Smith, M.A., Magill, C., Fallon, J.R., Yao, Y.M., Wallace, B.G., McMahan, U.J., 1987. Identification of agrin, a synaptic organizing protein from Torpedo electric organ. J Cell Biol 105, 2471-2478.

Ohno, K., Engel, A.G., Shen, X.M., Selcen, D., Brengman, J., Harper, C.M., Tsujino, A., Milone, M., 2002. Rapsyn mutations in humans cause endplate acetylcholine-receptor deficiency and myasthenic syndrome. Am J Hum Genet 70, 875-885.

Ohno, K., Sadeh, M., Blatt, I., Brengman, J.M., Engel, A.G., 2003. E-box mutations in the RAPSN promoter region in eight cases with congenital myasthenic syndrome. Hum Mol Genet 12, 739-748.

Pachter, B.R., Eberstein, A., 1984. Neuromuscular plasticity following limb immobilization. J Neurocytol $13,1013-1025$

Pachter, B.R., Eberstein, A., 1986. The effect of limb immobilization and stretch on the fine structure of the neuromuscular junction in rat muscle. Exp Neurol 92, 13-19.

Reynolds, A., Anderson, E.M., Vermeulen, A., Fedorov, Y., Robinson, K., Leake, D., Karpilow, J., Marshall, W.S., Klivorova, A., 2006. Induction of the interferon response by siRNA is cell type- and duplex length-dependent. RNA 12, 988-993.

Roorda, B.D., Hesselink, M.K., Schaart, G., Moonen-Kornips, E., Martinez-Martinez, P., Losen, M., De Baets, M.H., Mensink, R.P., Schrauwen, P., 2005. DGAT1 overexpression in muscle by in vivo DNA electroporation increases intramyocellular lipid content. J Lipid Res 46, 230-236.

Ruff, R.L., Lennon, V.A., 1998. End-plate voltage-gated sodium channels are lost in clinical and experimental myasthenia gravis. Ann Neurol 43, 370-379.

Ruff, R.L., Lennon, V.A., 2008. How myasthenia gravls alter's the safety factor for neuromuscular transmission. J Neuroimmunol 201-202, 13-20.

Santa, T., Engel, A.G., Lambert, E.G., 1972. Histometric study of neuromuscular junction ultrastructure. II. Myasthenic syndrome. Neurology 22, 370-376.

Seybold, M.E., Lambert, E.H., Lennon, V.A., Lindstrom, J.M., 1976. Experimental autoimmune myasthenia: clinical, neurophysiologic, and pharmacologic aspects. Ann N Y Acad Sci 274, 275-282.

Sledz, C.A., Holko, M., de Vear, M.J., Silverman, R.H., Willams, B.R., 2003. Activation of the interferon system by short-interfering RNAs. Nat Cell Blol 5, 834-839.

Sroka, H., Bornstein, B., Sandbank, U., 1975. Ultrastructure of the syndrome of continuous muscle fibre activity. Acta Neuropathol 31, 85-90.

Toyka, K.V., Brachman, D.B., Pestronk, A., Kao, 1., 1975. Myasthenia gravis: passive transfer from man to mouse. Sclence 190, 397-399. 


\section{G HAPER}

Tuschl, T., Zamore, P.D., Lehmann, R., Bartel, D.P., Sharp, P.A., 1999. Targeted mRNA degradation by double-stranded RNA in vitro. Genes Dev 13, 3191-3197.

VanSaun, M., Herrera, A.A., Werle, M.J., 2003. Structural alterations at the neuromuscular junctions of matrix metalloproteinase 3 null mutant mice. J Neurocytol 32, 1129-1142.

Verschuuren, J.J., Spaans, F., De Baets, M.H., 1990. Single-fiber electromyography in experimental autoimmune myasthenia gravis. Muscle Nerve 13, 485-492.

Wood, S.J., Slater, C.R., 1995. Action potential generation in rat slow- and fast-twitch muscles. J Plyysiol 486 (Pt 2), 401-410.

Wood, S.J., Slater, C.R., 1997. The contribution of postsynaptic folds to the safety factor for neuromuscular transmission in rat fast- and slow-twitch muscles. J Physiol 500 (Pt 1), 165-176.

Wood, S.J., Slater, C.R., 2001. Safety factor at the neuromuscular junction. Prog Neurobiol 64, 393-429.

Zhang, B., Luo, S., Dong, X.P., Zhang, X., Liu, C., Luo, Z., Xiong, W.C., Mei, L., 2007. Beta-catenin regulates acetylcholine receptor clustering in muscle cells through interaction with rapsyn. J Neurosci 27, 3968-3973.

Zhang, B., Luo, S., Wang, Q., Suzuki, T., Kiong, W.C., Mei, L., 2008. LRPA serves as a coreceptor of agrin. Neuron 60, 285-297. 
Table 1.Primer sequences for silencing rapsyn using pSUPER

5-1 f: 5'-GATCCCCTGAGAAGCTATGTGAGTTTttcaagagaAAACTCACATAGCTTCTCATTTTTGGAAA-3' s-1 r: 5'-AGCTTTTCCAAAAATGAGAAGCTATGTGAGTTTtctcttgaaAAACTCACATAGCTTCTCAGGG-3'

S-2 f: 5'-GATCCCCGGACTATGAGAAAGCCCTGttcagagagaCAGGGCTTTCTCATAGTCCTTTTTGGAAA-3' 5-2 r: 5'-AGCTTTTCCAAAAAGGACTATGAGAAAGCCCTGtctcttgaaCAGGGCTTTCTCATAGTCCGGG-3'

s-3 : f 5'-GATCCCCGGCTTTGGATGCCATTGAGttcaagagaCTCAATGGCATCCAAAGCCTTTTTGGAAA-3' 5-3 r: 5'-AGCTTTTCCAAAAAGGCTTTGGATGCCATTGAGtctcttgaaCTCAATGGCATCCAAAGCCGGG-3'

S-4 f: 5'-GATCCCCGCTGAGCCAGCTCAAGCTGttcaagagaCAGCTTGAGCTGGCTCAGCTTTTTGGAAA-3' 5-4 r: 5'-AGCTTTTCCAAAAAGCTGAGCCAGCTCAAGCTGtctcttgaaCAGCTTGAGCTGGCTCAGCGGG-3'

Table 2. Morphometric analysis of endplates in rapsyn-silenced, EAMG and control muscles*

\begin{tabular}{|c|c|c|c|c|c|c|}
\hline $\begin{array}{l}\text { Regions } \\
\text { Analyzed " }\end{array}$ & $\begin{array}{l}\text { Animals } \\
\text { per } \\
\text { group }\end{array}$ & $\begin{array}{l}\text { Nerve Bou- } \\
\text { ton Area } \\
\text { [1.mi'] }\end{array}$ & $\begin{array}{l}\text { Presynaptic } \\
\text { Membrane } \\
\text { Length } \\
\text { [um] }\end{array}$ & 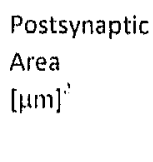 & $\begin{array}{l}\text { Postsynaptic } \\
\text { Membrane } \\
\text { Length } \\
\text { [1,m] }\end{array}$ & $\begin{array}{l}\text { Membrane } \\
\text { Length Ratio } \\
\text { (Postsynaptic } \\
\text { Presynaptic) }\end{array}$ \\
\hline 197 & 6 & $2.8 \pm 0.12$ & $3.2 \pm 0.38$ & $6.52 \pm 4.44$ & $14.4 \pm 1.62$ & $3.3 \pm 0.17 c$ \\
\hline 182 & $G$ & $2.3 \pm 0.15 b$ & $3.9 \pm 0.50$ & $8.30 \pm 7.60 b$ & $37.4 \pm 5.14$ & $4.9 \pm 0.52 c$ \\
\hline 92 & 3 & $2.7 \pm 0.11$ & $2.2 \pm 0.91$ & $6.89 \pm 4.83$ & $8.8 \pm 0.63 c$ & $2.4 \pm 0.276$ \\
\hline
\end{tabular}

* Mean $上$ SE

"a region here refers to an area of one synaptic bouton and the adjacent postsynaptic membrane

" significantly different from control endplates ( $p<0.05)$

significantly different from all other conditions $(p<0.05)$

other differences in this table are not significant $(p>0,05)$

Table 3. Morphometric analysis of endplates following $\alpha$-BT treatment*

\begin{tabular}{lclllll}
\hline & $\begin{array}{l}\text { Regions } \\
\text { Analyzed" }\end{array}$ & $\begin{array}{l}\text { Nerve } \\
\text { Bouton } \\
\left.\text { Area }[\mu \mathrm{m}]^{\prime}\right]\end{array}$ & $\begin{array}{l}\text { Presynaptic } \\
\text { Membrane }\end{array}$ & $\begin{array}{l}\text { Postsynaptic } \\
\text { Area } \\
{[\mu \mathrm{m}]^{\prime}}\end{array}$ & $\begin{array}{l}\text { Postsynaptic } \\
\text { Membrane } \\
{[\mu \mathrm{m}]}\end{array}$ & $\begin{array}{l}\text { Membrane } \\
\text { Length Ratio } \\
\text { (Postsynap- } \\
\text { tic/Presynaptic) }\end{array}$ \\
\hline Saline-Treated & 139 & $2.4 \pm 1.5$ & $8.0 \pm 5.2$ & $7.75 \pm 4.50$ & $32.7 \pm 18.9$ & $4.5 \pm 2.0$ \\
$\alpha-B T$-Treated & 150 & $2.9 \pm 1.8$ & $12.2 \pm 10.5^{\prime \prime}$ & $11.98 \pm 15.29^{\prime \prime}$ & $55.2 \pm 53.2^{\prime \prime}$ & $4.6 \pm 2.5$ \\
\hline
\end{tabular}

Mean 1 SE

"a region here refers to an area of one or more synaptic boutons

"significantly different from saline-treated control endplates ( $p<0.05)$; other differences in this table are not significant $(p=0.05)$ 

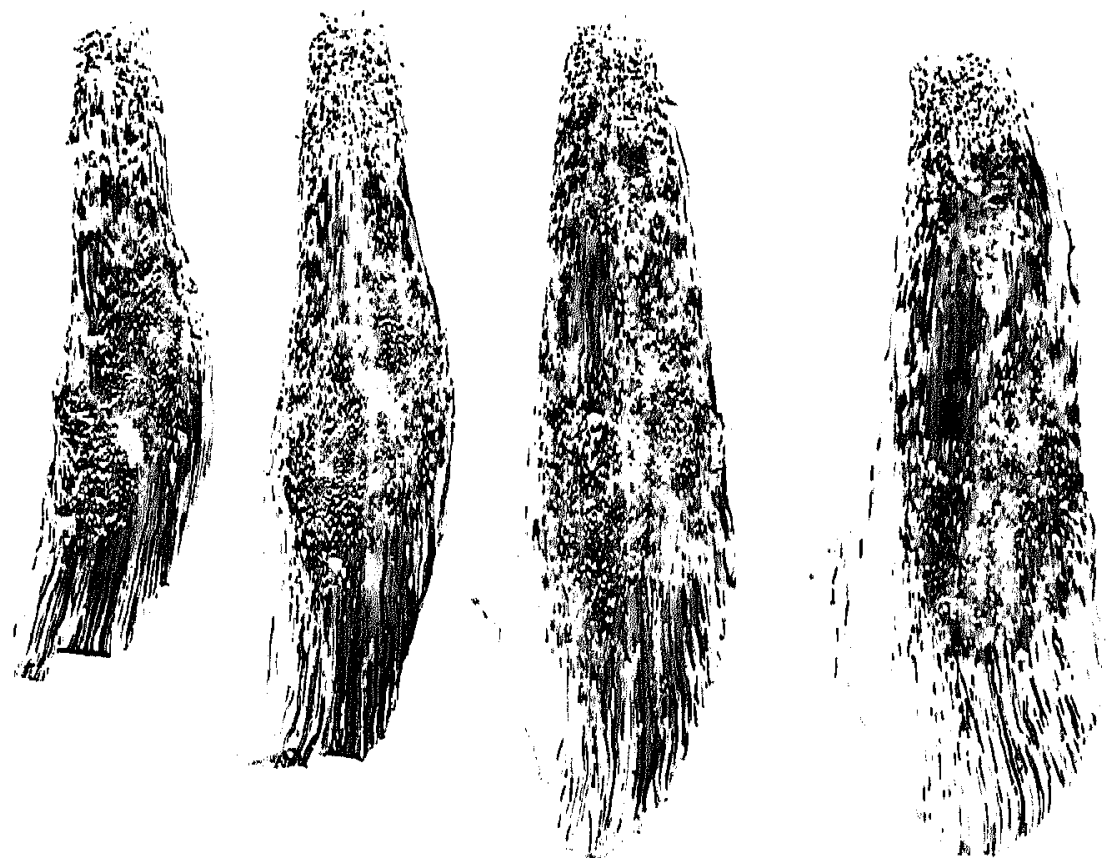

Figure 1. In vivo electroporation of shRNA plasmids. The transfection efficiency was analyzed using $X$-gal as a substrate for the reporter $\beta$-galactosidase. The sections are spaced $500 \mu \mathrm{m}$ 


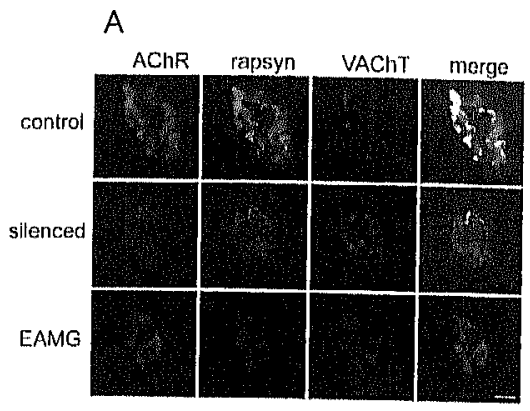

B

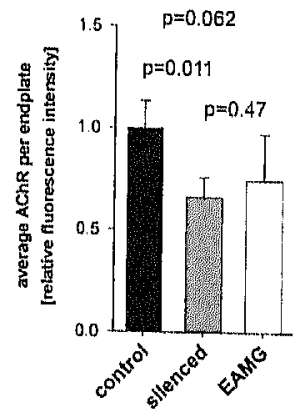

C

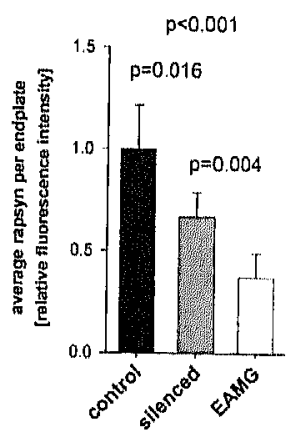

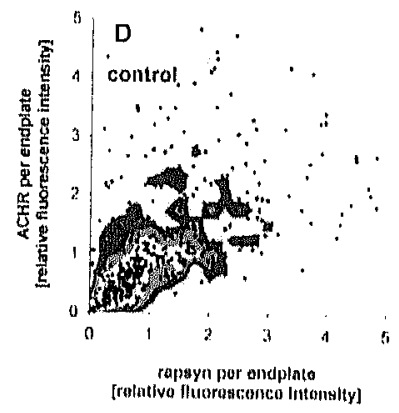
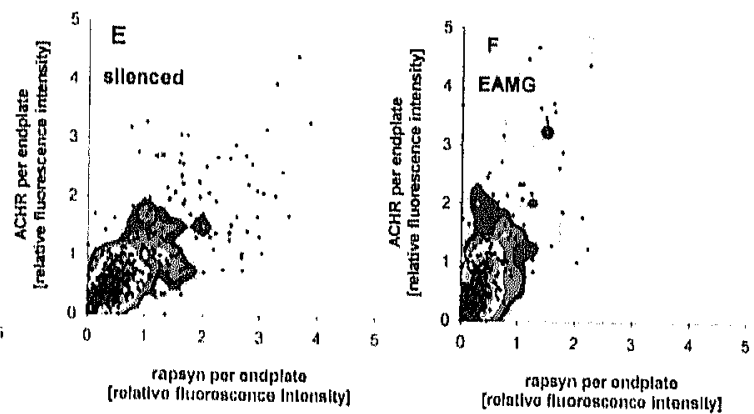

Figure 2. Two-photon laser scanning microscopy inages of representative endplates and quantitative immunohistochemistry analysis. Muscle sections were triple stained for ACliR (red), rapsyn (green) and the presynaptic protein VAChT (blue) as a reference. (A) In rapsyn-silenced muscles most endplates showed reduced $A C l R$ and rapsyn levels relative to VAChT. Passive transfer of anti-AChR antibodies caused a similar reduction of these proteins. Scale bar is $10 \mu \mathrm{m}$. Mensurement of fluorescence intensities of $A C h R(B)$ and rapsyn (C) relative to VAChT staining of endplates in 5 control, 5 silenced and 6 EAMG muscles. Error bars indicate the standard deviation. At least 120 endplates were analyzed per muscle. Staining intensities were normalized to the average intensities of control endplates. The distribution of nomalized staining intensities of individual endplates is shown for control muscles (D), silenced muscles (E) and EAMG muscles (F). 
A

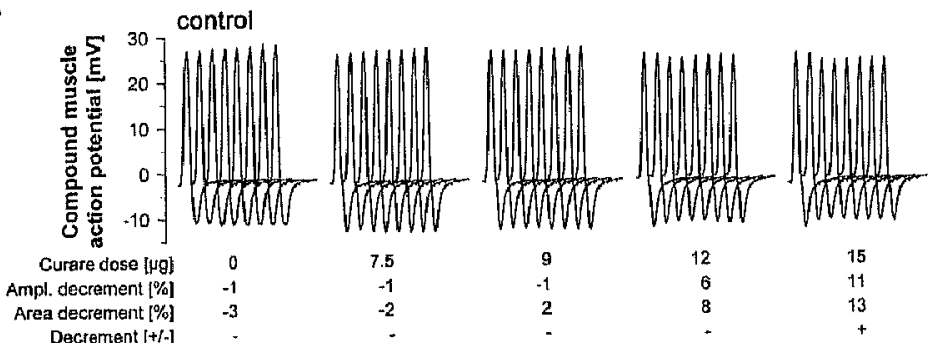

$B$
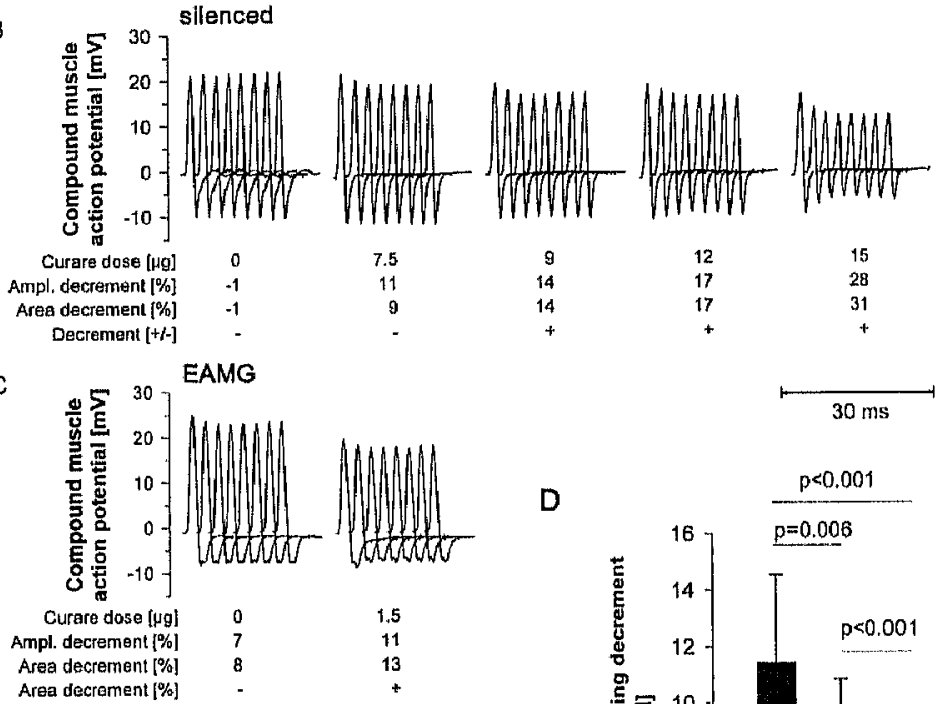

Figure 3

$\begin{array}{rrr}9 & 12 & 15 \\ 14 & 17 & 28 \\ 14 & 17 & 31 \\ + & + & +\end{array}$

Area decrement [\%]

13

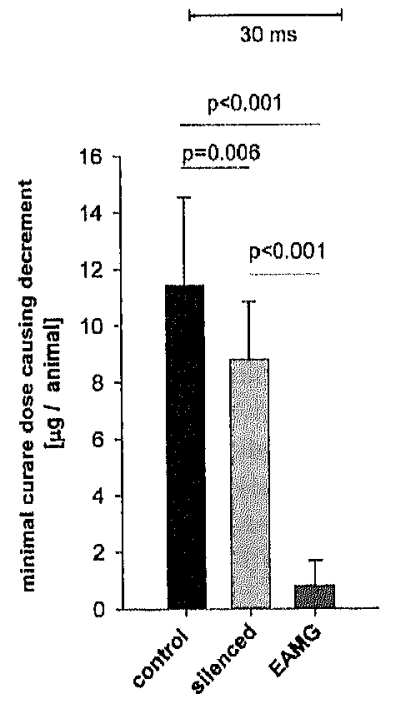

Figure 3. Measurement of curare sensitivity of neuromuscular transmission. Compound muscle action potentials of the transfected tibialis anterior muscles were measured bilaterally during repetitive nerve stimulation. Doses of curare were injected repeatedly with 10 mimutes intervals until a reproducible decremental response was observed in both muscles. The minimal cumulative curare dose that caused decrement in control muscles (an example is shown in A) was always higher than in the contralateral rapsyn-silenced muscles (example in B). In EAMG animals decrement could be induced without or with very low doses of curare (C). (D) Average minimal cumulative curare dose that induced at least $10 \%$ decrement of the CMAP in 5 control muscles, 5 silenced muscles and muscles of 5 EAMG animals. Error bars indicate the standard deviation. 

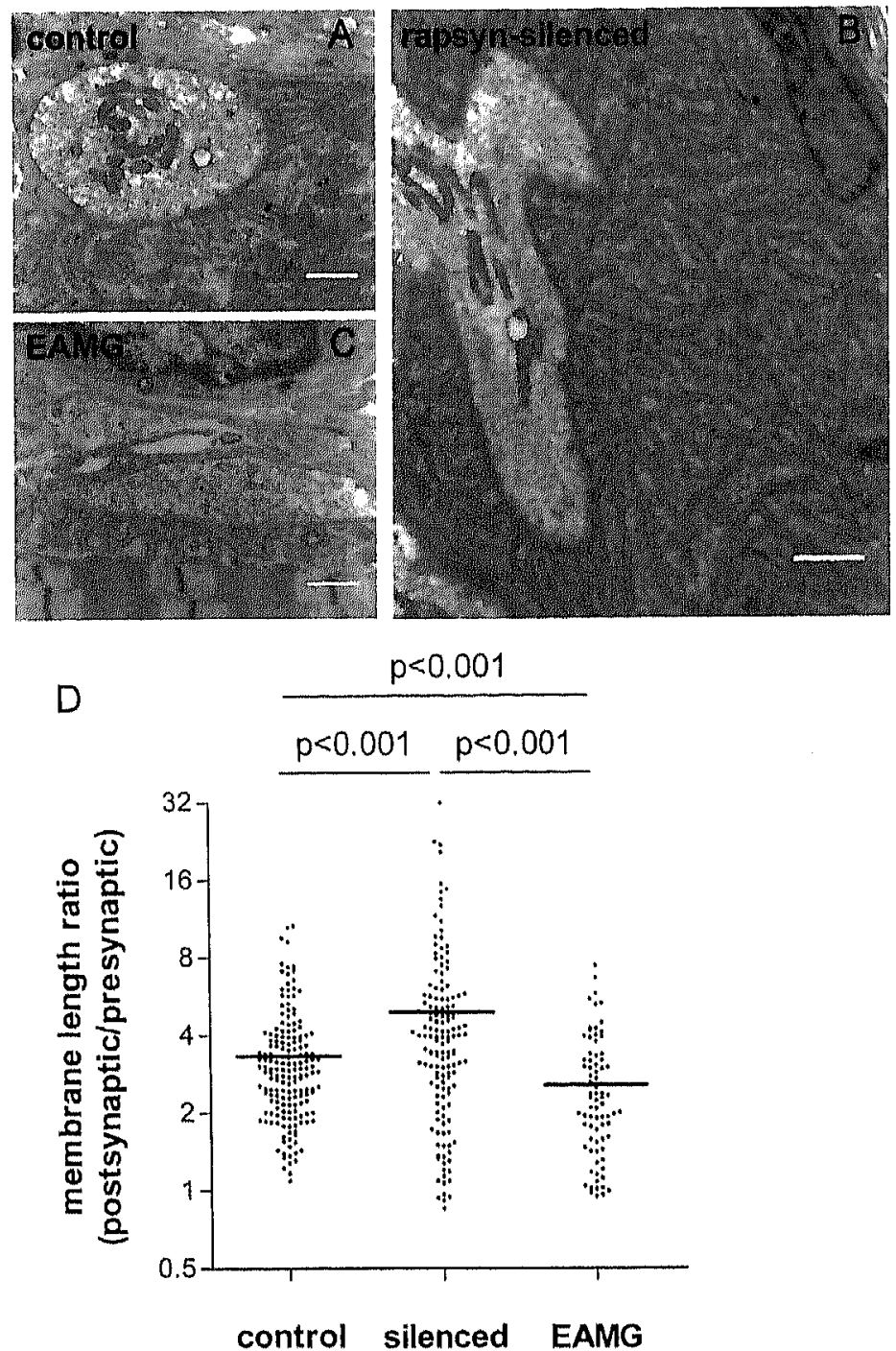

Figure 4. Electron microscopic analysis of endplate morphology (scale bar $1 \mu \mathrm{m}$ ). (A) Normal endplate region in a control muscle. (B) Endplates in the contralateral rapsyn-silenced muscle of the same animal showed varying degrees of increased secondary folds. Shown is a conspicuous example. (C) Passive transfer of anti-AChR antibodies causes widening of the synaptic cleft and a reduction of postsynaptic folding. (D) Quantitative morphometric analysis of the postsynaptic folding index. Each data point represents the ratio of the total postsynaptic membrane length (including primary gutter and secondary clefts) and the presynaptic membrane of one or two nerve corresponding nerve boutons (folding index). Note that the ordinate is a logarithmic scale. Other parameters of the quantitative morphometric analysis are presented in Table 2. 

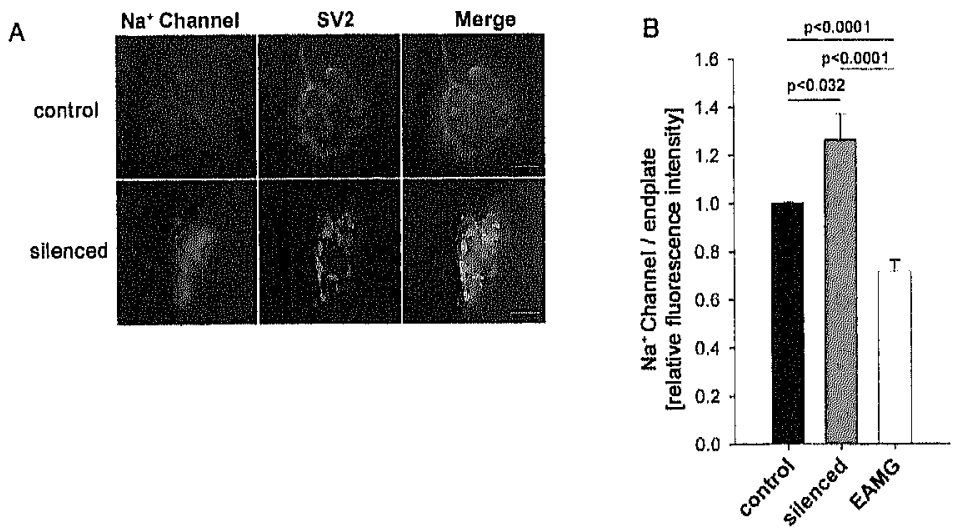

Figure 5. Analysis of postsynaptic VGSC expression. (A) Confocal microscopy images of representative endplates. Muscle sections were stained for sodium channel (red), and the presynaptic vesicle protein 2 (SV-2; green) as a reference. In rapsyn-silenced muscles most endplates showed increased sodium channel levels compared to control endplates. Scale bar is $10 \mu \mathrm{m}$. (B) Measurement of fluorescence intensities of VGSCs relative to presynaptic SV-2 staining in control, rapsyn-silenced and EAMG muscles. Error bars correspond to the standard deviations. Staining intensities were normalized to the average intensities of contral endplates.
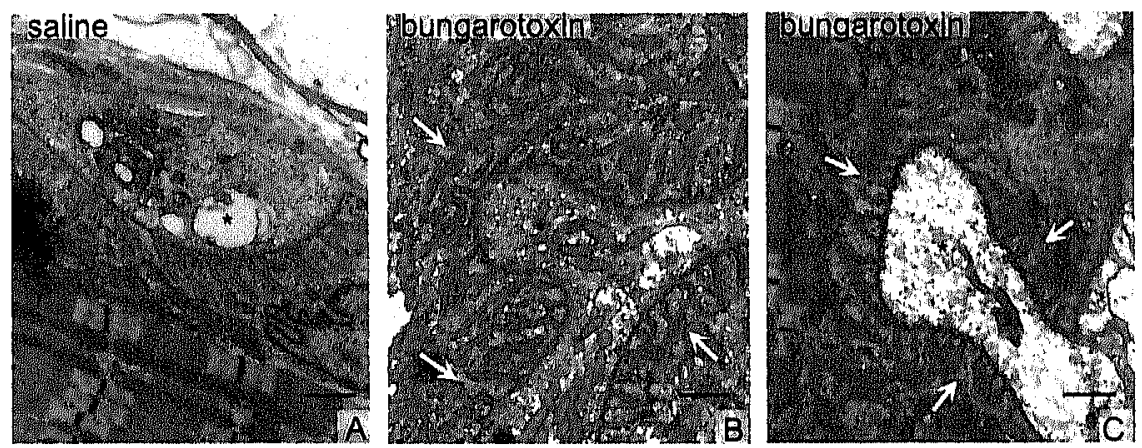

Figure 6. Electron microscopic examination of neuromuscular junctions in saline-treated (A) and $\alpha$-BT treated ( $B$ and $C$ ) tibialis anterior muscles. Arrows indicate an enlarged contact area between the preand the postsynaptic membrane; stars indicate the nerve boutons; scale bars are $1 \mu \mathrm{m}$. 
RADSYA SHENCING UNO VIVO

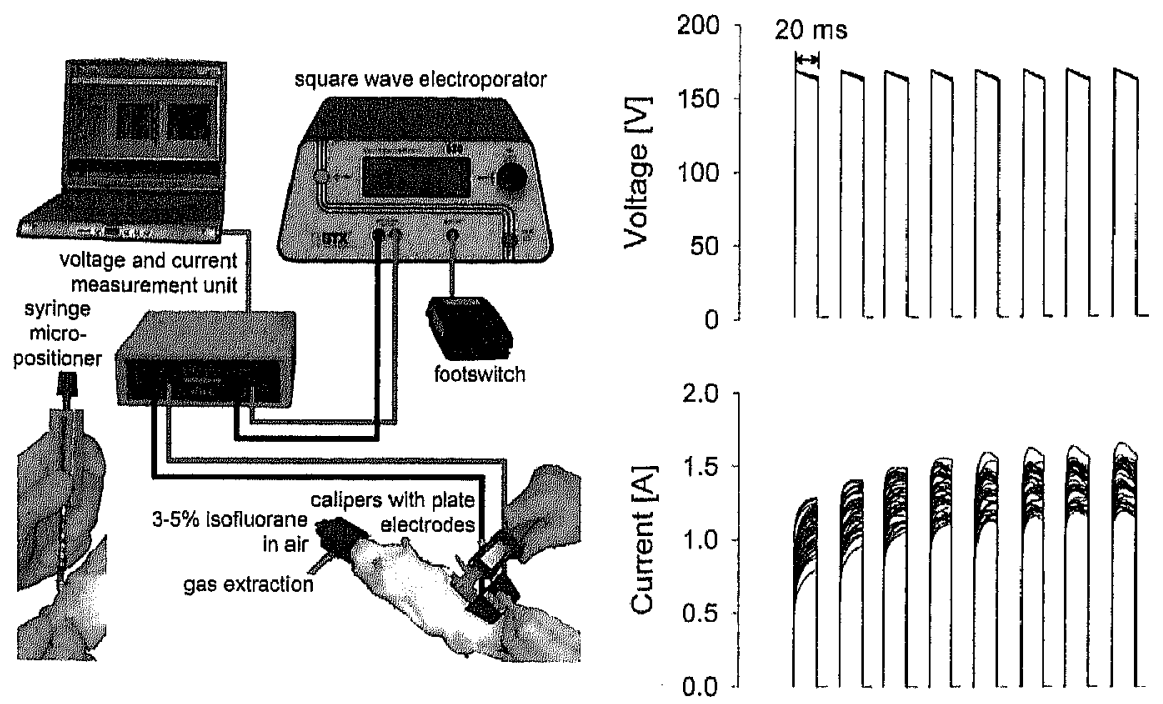

Figure S1. In vivo electroporation scheme. Scheme of the electroporation set up. In each electroporation the voltage and the current were recorded. 
A PSUPER

\section{S-1}

S-2

S-3

S-4

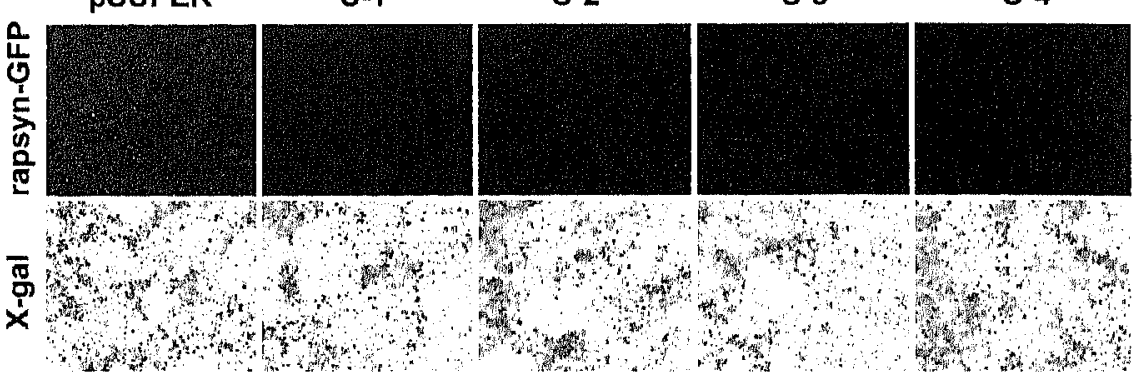

B

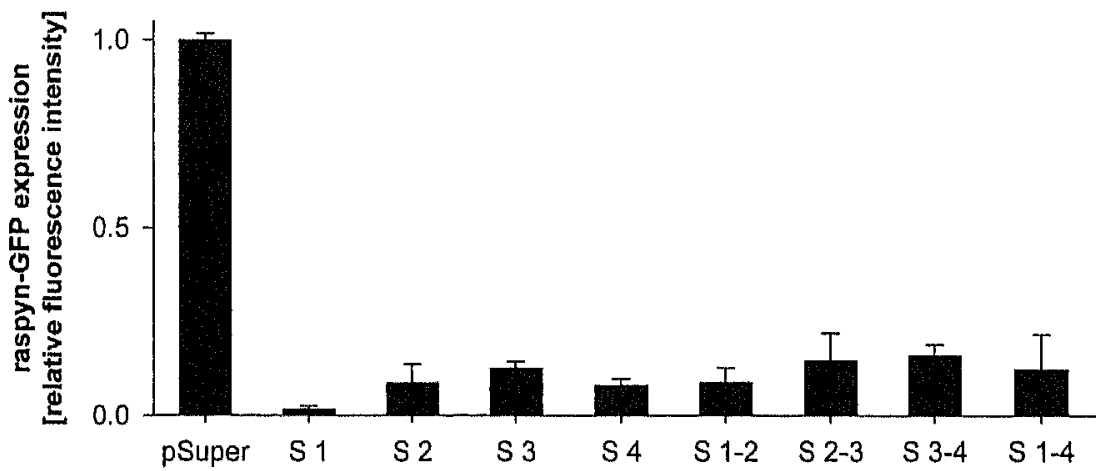

Figure 52. In vitro analysis of shRNA efficiency. (A) HEK 293 cells were co-transfected with plasmids for the expression of rapsyn-GFP, $\beta$-galactosidase and anti-rapsyn shRNAs (S-1, S-2, S-3, S-4) or the empty shRNA expression plasmid PSUPER. Co-transfection of rapsyn-GFP with anti-rapsyn shRNA strongly reduced rapsyn expression compared to cells transfected with the empty PSUPER plasmid. The $\beta$-gal expression shows that the transfection efficiency of HEK cells was similar in all tests. (B) The average GFP expression in the cells of 4 transfected wells was quantified and normalized relative to GFP expression in cells transfected with the empty pSUPER. Error bars indicate the standard error of the means of two independent experiments. 


\section{VAChT}

Rapsyn

Merge

\section{Control}

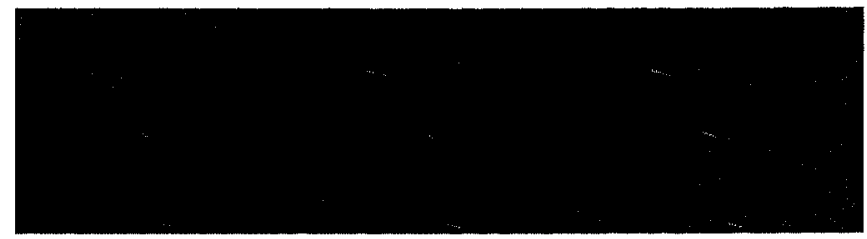

\section{Silencing}

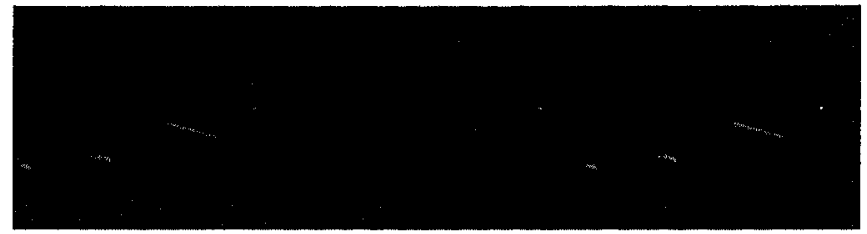

Silencing

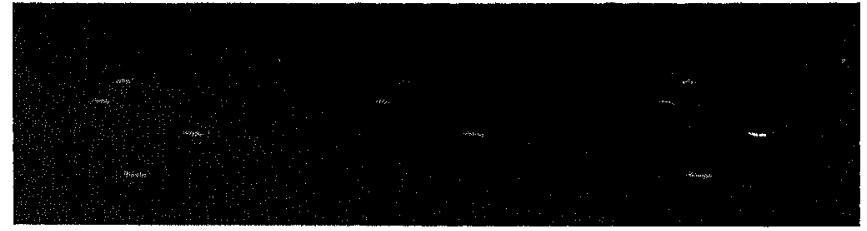

Silencing

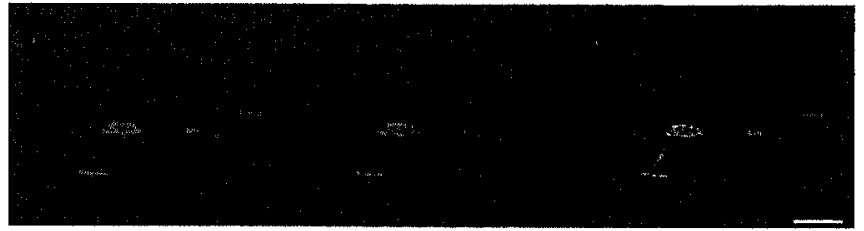

\section{Supplemental Figure S3}

Figure \$3. In vivo experiments showing silencing efficiency of rapsyn p5UPER constructs in single electroporated muscles. The pictures show a double staining of VAChT (red) a presynaptic protein and rapsyn (green). The first panel contains endplates from a tiblalis anterior muscle electroporated with pSUPER empty vector, not showing any decrease in rapsyn. The lower 3 panels show endplates from tiblalis anterior muscles electroporated with silencing vectors (S-1, S-2, S-3, S-4) where the rapsyn levels decreased or disappeared (see merge). 
CWARER

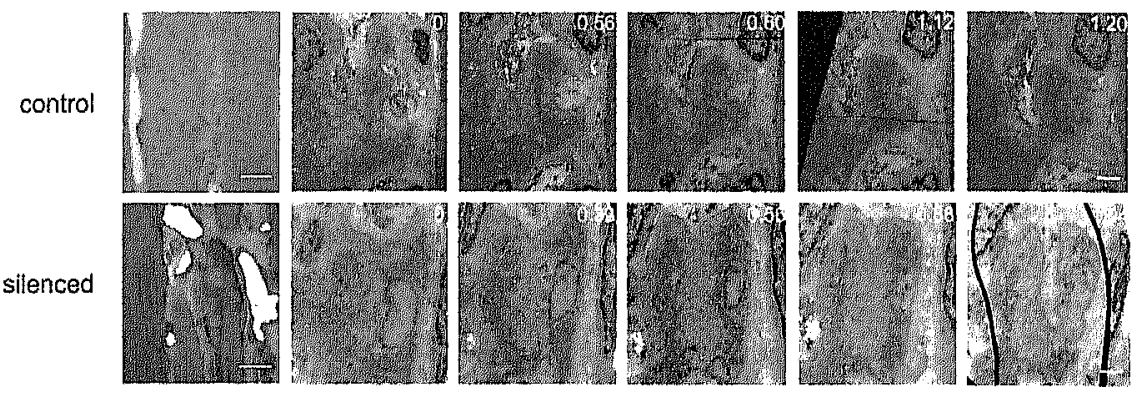

Figure S4. Study of endplate morphology from control and silenced muscles in consecutive sections. The most left figures show Toluidine Blue stained light microscopic slices $(0.3 \mu \mathrm{m}$, magn. 100x), the other pictures are electron microscopic (EM) slices $(80 \mathrm{~nm})$. Scale bars are $2 \mu \mathrm{m}$. The numbers at the pictures give an indication of the distance to the first EM-slice in $\mu \mathrm{m}$ (Z-axis). 


\section{Chapter 5}

\section{Prevention of acetylcholine receptor modulation in myasthenia gravis}

Mario Losen, Pilar Martínez-Martinez, Marko Phernambucq, Janine Schuurman,

Paul W.H.I. Parren and Marc De Baets 
CHAPTER

\section{Introduction}

\section{Effector mechanisms of autoantibodies in myasthenia gravis}

The immune system protects the body against pathogens by eliminating non-self antigens. Immune responses are highly regulated to avoid hypersensitivity and wasted resources when the pathogens are eliminated. In spite of this regulation and mechanisms for clonal deletion of many self-reactive lymphocytes, the immune system occasionally attacks self-tissues and produces autoimmunity. Since the discovery of the autoimmune mechanism of myasthenia gravis by Patrick and Lindstrom in 1973 (Patrick and Lindstrom, 1973) (which confirmed a hypothesis that had already been proposed by Simpson in 1960 (Simpson, 1960) the role of the acetylcholine receptor (AChR) as an autoantigen, and the effect of anti-AChR autoantibodies have been analyzed in detail. More recently, the muscle-specific kinase (MUSK) has been discovered as a second auto-antigen in a subgroup of MG patients without anti-AChR antibodies (Hoch et al., 2001). In contrast to AChR-MG patients, the majority of MuSK-MG patients have prevalent involvement of facial and bulbar muscles (Farrugia et al., 2006; Lavrnic et al., 2005), which possibly reflects a different composition of the neuromuscular junction (NMJ) in these muscles. More autoantigens might exist in the postsynaptic membrane of the NMJ, because in some MG patients neither anti-AChR antibodies, nor anti-MuSK antibodies are detectable by immunoprecipitation of radiolabeled antigens. Following the example of MG, surface autoantigens have also been identified in other autoimmune-diseases of the peripheral nervous system such as the Lambert-Eaton myasthenic syndrome and the GuillainBarré syndrome. Moreover, there is accumulating evidence that autoantibodies can also cause or aggravate disorders of the central nervous system (Irani and Lang, 2008).

Anti-AChR antibodies are the cause of the characteristic chronic muscle weakness in $85 \%$ MG patients. The antibodies result in the destruction of the postsynaptic membrane of the NMJ and functional denervation. Anti-AChR antibodies of all IgG subclasses have been found in MG patients, but the only isotype that is always present is IgG1 (Rodgaard et al., 1987). Pathogenic mechanisms may include damaging the NMJ by focal lysis of the postsynaptic membrane due to complement activation (Chamberlain-Banoub et al., 2006; Lennon et al., 1978; Tuzun et al., 2003), cross-linking of AChRs, leading to increased internalization and degradation of the receptors (antigenic modulation) (Heinemann et al., 1977; Kao and Drachman, 1977; Loutrari et al., 1992), loss of receptor associated proteins (Martinez-Martinez et al., 2007), inhibition of ion channel function (Lang et al., 1988) and blocking of the ACh binding site (Almon et al., 1974; Gomez and Richman, 1983). The extracellular domain of the $\alpha 1$ subunit contains the main immunogenic region (MIR), to which a major part of the pathogenic EAMG antibodies and possibly also a major part of MG 
auto-antibodies is directed (Tzartos et al., 1998; Tzartos et al., 1991; Tzartos and Lindstrom, 1980; Tzartos et al., 1982). Anti-MIR antibodies are also very effective in antigenic modulation.

The effects of auto-antibodies directed to the proteins of the NMJ can be studied in an animal model of $M G$, termed experimental autoimmune myasthenia gravis (EAMG) (De Baets et al., 2003). The original experimental model, which led to the discovery of the cause of MG, is the immunization of rabbits with the AChR from the electric organ of Electrophorus electricus (chronic EAMG) (Patrick and Lindstrom, 1973). Subsequently, the similarity to human MG was demonstrated by immunizing rhesus monkeys (Macaca mulatta) with repeated doses of Torpedo californica AChR (Tarrab-Hazdai et al., 1975). In a rodent chronic EAMG model, a sub-population of antibodies against the Torpedo or Electrophorus AChR that cross-react with the $A C h R$ of immunized animal were identified as the cause of the damage to the NMJ, leading to a long-lasting disease (Lindstrom et al., 1976b). Sera from MG patients (Toyka et al., 1975; Toyka et al., 1977), AChR-immunized animals (Lindstrom et al., 1976a) and monoclonal anti-AChR antibodies (Tzartos and Lindstrom, 1980) have also been shown to induce MG symptoms when injected in naïve animals (passive transfer EAMG). Passive transfer causes transient muscular weakness that can last for several days.

The NMJ responds to the autoantibody attack by changing the expression of a number of proteins. The AChR and complement regulatory proteins are upregulated to compensate for receptor loss and limit further damage to the NMJ(Guyon et al., 1998; Kaminski et al., 2004). Many changes however are a consequence of functional denervation of the muscle with concomitant loss of postsynaptic specialization. Thus, the study of the underlying mechanisms of maintenance of postsynaptic organization is important for understanding the susceptibility to the autoantibody attack and the recovery of the damaged postsynaptic membrane.

\section{Antigen specific therapies for protection against autoantibodies}

Current therapies for autoimmune diseases aim at suppressing the immune system by removal of antibodies using plasmapheresis, or by pharmacological inhibition of lymphocyte proliferation. However, these therapies are not specific for the autoimmune response, and have to be carefully balanced to prevent an unacceptable increase of susceptibility to infections and cancer. For this reason complete remission of autoimmune diseases is difficult to achieve by general immunosuppression. To avoid this intrinsic dilemma, antigen specific therapies are required. These can target the $\mathrm{T}$ - and $\mathrm{B}$-cell clones that mount the immune response, the autoantigenspecific antibodies or the target tissue. Several specific immunotherapy approaches have been tested in EAMG models, including anti-idiotypic antibodies (Souroujon et al., 1986; Verschuuren et al., 1991), a peptide that competes with a pathogenic mAb 
for binding with AChR (Luo et al., 2001), induction of tolerance by administration of AChR (Wang et al., 1993) or AChR-derived synthetic peptides (Im et al., 2001), and elimination of AChR-specific $T$ cells by genetically engineered antigen-presenting cells (Wu et al,, 2001). None of these therapeutic approaches have led to an efficient MG therapy so far.

Gene therapy of the target tissue is a promising therapeutic approach for protecting the autoantigen. Possible protective molecules include anti-inflammatory cytokines and complement regulatory proteins. 'Regenerative gene therapy' aims at supplying critical proteins required for the protection and recovery of the target tissue, e.g. rapsyn transfection in muscles discussed below. However, a critical limitation of gene therapy is currently the lack of safe and efficient vectors. Conversely, immunotherapy with monoclonal human antibodies has been proven to be efficacious and side effects are usually mild. Current treatments using monoclonal antibodies in autoimmunity are not antigen specific, but have a general immunosuppressive effect. Autoantigen-specific immunoglobulins without pathogenic properties could specifically block important epitopes on the target tissue and thereby prevent auto-antibody binding.

\section{AChR specific lgG4 immunotherapy}

Passive transfer studies in EAMG in rats and mice have shown promise for the use of Fab fragments of anti-AChR antibodies that compete with pathogenic IgG in protection against disease (Loutrari et al., 1992; Papanastasiou et al., 2000; Richman et al., 1998; Toyka et al., 1980). The antibody fragments exert their action through monovalent binding (Figure $1 \mathrm{C}$ ), thus preventing cross-linking of the AChR (Figure 1B). Treatments with antibody fragments, however, are not practical because of their very short half-life in vivo. Monovalent binding to antigens is not limited to Fab fragments, but also IgG4 antibodies are functionally monovalent. IgG4 antibodies become unable to crosslink identical antigens in vivo by IgG4 Fab arm exchange (van der Neut Kolfschoten et al., 2007). IgG4s undergo Fab arm exchange by replacing an IgG heavy chain and attached light chain (half-molecule) for a heavy-light chain pair from another IgG4 molecule (Figure 1A). IgG4 molecules can thereby acquire two distinct Fab arms recognizing two distinct antigens and therefore do not crosslink under most conditions with only one Fab arm recognizing a specific antigen (while the other arm, derived for the polyclonal pool of IgG4 in plasma, is directed to a different and, in most instances, irrelevant antigen).

Similar to Fab fragments, Fab arm exchanged antibodies may interfere with antibody clustering and thus inhibit antigen internalization. Since antigenic modulation is an important pathogenic mechanism in myasthenia gravis we investigated whether Fab arm exchanged IgG4 antibodies could be used therapeutically. We 
produced human $\operatorname{IgG} 1$ and $\operatorname{IgG} 4$ isotypes of a patient-derived anti-AChR antibody and analyzed their properties both in vitro and in vivo.

IgG1-637 and IgG4-637 were produced from Fab-637, which binds to the main immunogenic region (MIR) of human AChR. Fab-637 was previously isolated from a phage display library prepared from the thymus of an MG patient (Graus et al., 1997) and was found to compete with patient sera for binding to the MIR without interfering with the ion channel function.

Because crosslinking of $A C h R$ by antibody causes antigenic modulation and degradation of AChR in cell culture, we tested the effect of IgG1-637 and IgG4-637 on AChR expressing thabdomyosarcoma TE671 cells. IgG1-637 and IgG4-637 were found to bind AChR with similar affinity and reduced the cell surface AChR levels to the same extent, indicating that both recombinant antibodies caused antigenic modulation by cross-linking AChR in vitro (van der Neut Kolfschoten et al., 2007).

In a passive transfer MG model using rhesus monkeys we showed that the IgG4 antibody is non-pathogenic and protects against $\lg G 1$-induced disease. To assess whether IgG4 Fab arm exchange may be responsible for protecting the NMJ in our monkey model, we assessed the cross-linking capacity of anti-AChR antibodies in serum drawn from monkeys at different time points. Consistent with in vivo IgG4 Fab arm exchange, however, the serum from a monkey injected with IgG4-637 caused almost no antigenic modulation of $A C h R$, in contrast to the serum from a monkey injected with IgG1-637. Receptor modulation by serum of an animal injected with both IgG1-637 and lgG4-637 was also reduced. Because AChR degradation is dependent on cross-linking, and the IgG4-637 antibody was able to induce severe AChR down modulation prior to injection, this confirms that the IgG4 antibody acquired its non-crosslinking behavior by Fab arm exchange in vivo.

\section{The role of rapsyn in antigenic modulation}

The AChR is clustered and anchored in the postsynaptic membrane of the NMJ by the receptor associated protein of the synapse, rapsyn. Rapsyn metabolically stabilizes the AChR, as shown by cotransfection of rapsyn and AChR expression plasmids (Phillips et al., 1997; Wang et al., 1999), and reduces the antigenic modulation of AChRs induced by the AChR monoclonal antibody (mAb)-35 in transfected fibroblasts (Phillips et al., 1997). We hypothesized that increased rapsyn expression might stabilize the AChR and prevent antigenic modulation by anti-AChR autoantibodies also in vivo. For this purpose we used an experimental autoimmune myasthenia gravis (EAMG) model using rats. In rats, EAMG can be induced by passive transfer of AChR mAbs, eg. mAb 35, as well as by active immunization using Torpedo AChR. Resistance to experimental autoimmune MG (EAMG) in aged rats correlates with increased rapsyn concentration at the NMJ (Gervasio et al., 2007; Gervasio and Phillips, 2005; Hoedemaekers et al., 1998). The role of rapsyn in EAMG 
was first tested by transfecting tibialis anterior muscles with a rapsyn expression plasmid in young rats that are susceptible to the disease (Losen et al., 2005). We used in vivo electroporation to over-express rapsyn unilaterally in one tibialis anterior and subsequently induced acute EAMG in voung rats by passive transfer of the anti-AChR antibody $\mathrm{mAb} 35$. In healthy rats transfected muscle fibers had extrasynaptic rapsyn aggregates, as well as slightly increased rapsyn and AChR concentrations at the NMJ. In EAMG rats, despite deposits of the membrane attack complex, the rapsyn-overexpressing muscles showed no decrement in the compound muscle action potentials, no loss of $A C h R$, and the majority had normal postsynaptic folds, whereas endplates of untreated muscles showed typical AChR loss and morphological damage.

We next investigated the therapeutic potential of rapsyn-overexpression, by first inducing chronic EAMG with Torpedo AChR in susceptible rats and then used electroporation when the endplates were damaged by cross-reacting anti-AChR antibodies. This treatment aggravated the destruction of the endplates, because of an increased turnover of rapsyn-AChR clusters in the damaged and simplified muscle membrane, that lacked other essential anchoring proteins such as utrophin (Martinez-Martinez et al., 2007).

\section{Discussion}

The prevention of antigenic modulation of the $A C h R$ is a possible therapy for MG. The importance of antigenic modulation in the disease was demonstrated in a rat EAMG model using the AChR clustering protein rapsyn. Overexpression of rapsyn was able to prevent $A C h R$ modulation by bivalent antibodies, despite of complement activation. The stabilization of AChR with rapsyn was functional in an intact postsynaptic membrane, but not in damaged endplates lacking utrophin and other AChR anchoring proteins. Although unregulated rapsyn-overexpression can therefore not be used therapeutically these results have clearly shown the key role of AChR-modulation in MG.

Interestingly, the human immune system has a natural mechanism to prevent antigenic modulation by antibodies: Fab arm exchange equips an IgG4 anti-AChR antibody with the ability to inhibit IgG1-mediated receptor down modulation and thereby preventing autoimmune myasthenia gravis. Indeed, the ability of IgG4-AChRtreated monkey sera to inhibit antigenic modulation of AChR correlates well with its ability to prevent disease. It has been previously suggested that antigenic modulation is not sufficient for the induction of $M G$, and that complement activation may also be required (Berman and Heinemann, 1984; Lennon et al,, 1978). Here we demonstrate the importance of antigenic modulation and the potential in vivo consequences of IgG4 Fab arm exchange. We show that IgG4 Fab arm exchange may 
result in the formation of non-crosslinking antibodies, which inhibit the pathogenic activity of an IgG1 antibody. Fab arm exchange therefore provides IgG4 antibodies with the ability to dampen inflammation induced by other antibody isotypes. The concept of disease-blocking IgG4 antibodies provides a basis for the development of immunotherapy for MG as well as other antibody mediated autoimmune diseases, allergies and inflammatory diseases.

\section{References}

Almon, R.R., Andrew, C.G., Appel, S.H., 1974. Serum globulin in myasthenia gravis: inhibition of alphabungarotoxin binding to acetylcholine receptors. Science $186,55+57$.

Berman, P.W., Heinemann, S.F., 1984. Antigenic modulation of junctional acetylcholine receptor is not sufficient to account for the development of myasthenia gravis in receptor immunized mice. J Immunol 132, 711-717.

Chamberlain-Banoub, J., Neal, J.W., Mizuno, M., Harris, C.L., Morgan, B.P., 2006. Complement membrane attack is required for endplate damage and clinical disease in passive experimental myasthenia gravis in Lewis rats. Clin Exp Immunol 146, 278-286.

De Baets, M., Stassen, M., Losen, M., Zhang, X., Machiels, B., 2003. Immunoregulation in experimental autoimmune myasthenia gravis-about T cells, antibodies, and endplates. Ann N Y Acad Sci 998 308-317.

Farrugia, M.E., Robson, M.D., Clover, L., Anslow, P., Newsom-Davis, J., Kennett, R., Hilton-Jones, D. Matthews, P.M., Vincent, A., 2006. MRI and clinical studies of facial and bulbar muscle involvement in MuSK antibody-associated myasthenia gravis. Brain 129, 1481-1492.

Gervasio, O.L., Armson, P.F., Plillips, W.D., 2007. Developmental increase in the amount of rapsyn per acetylcholine receptor promotes postsynaptic receptor packing and stability. Dev Biol 305, 262-275.

Gervasio, O.L., Phillips, W.D., 2005. Increased ratio of rapsyn to ACh receptor stabilizes postsynaptic receptors at the mouse neuromuscular synapse. J Physiol 562, 673.685.

Gomez, C.M., Richman, D.P., 1983. Anti-acetylcholine receptor antibodies directed against the alphabungarotoxin binding site induce a unique form of experimental myasthenia. Proc Natl Acad Sci U 5 A $80,4089-4093$.

Graus, Y.F., de Baets, M.H., van Breda Vriesman, P.J., Burton, D.R., 1997. Anti-acetylcholine receptor Fab fragments isolated from thymus-derived phage display libraries from myasthenia gravis patients reflect predominant specificities in serum and block the action of pathogenic serum antibodies. Immunol Lett $57,59-62$

Guyon, T., Wakkach, A., Poea, S., Mouly, V., Klingel-Schmitt, I., Levasseur, P., Beeson, D., Asher, O., Tzartos, S., Berrih-Aknin, S., 1998. Regulation of acetylcholine receptor gene expression in human myasthenia gravis muscles. Evidences for a compensatory mechanism triggered by receptor loss. I Clin Invest $102,249-263$.

Heinemann, S., Bevan, S., Kullberg, R., L.'ndstrom, J., Rice, J., 1977. Modulation of acetylcholine receptor by antibody against the receptor. Proc Natl Acad Sci U S A 74, 3090-3094.

Hoch, W., McConville, J., Helms, S., Newsom-Davis, J., Melms, A., Vincent, A., 2001. Auto-antibodies to the receptor tyrosine kinase MuSK in patients with myasthenia gravis without acetylcholine receptor antibodies. Nat Med 7, 365-368.

Hoedemaekers, A., Bessereau, J.L., Graus, Y., Guyon, T., Changeux, J.P., Berrih-Aknin, S., van Breda Vriesman, P., De Baets, M.H., 1998. Role of the target organ in determining susceptibility to experimental autoimmune myasthenia gravis. J Neuroimmunol 89, 131-141. 
Im, S.H., Barchan, D., Maiti, P.K., Raveh, L., Souroujon, M.C., Fuchs, S., 2001. Suppression of experimental myasthenia gravis, a B cell-mediated autoimmune disease, by blockade of IL-18. Faseb J 15, 21402148.

Irani, S., Lang, 8., 2008. Autoantibody-mediated disorders of the central nervous system. Autolmmunity $41,55-65$

Kaminski, H.J., Li, Z., Richmonds, C., Lin, F., Medof, M.E., 2004. Complement regulators in extraocular muscle and experimental autoimmune myasthenia gravis. Exp Neurol 189, 333-342.

Kao, I., Drachman, D.B., 1977. Myasthenic immunoglobulin accelerates acetylcholine receptor degradation. Science 196, 527-529.

Lang, B., Richardson, G., Rees, J., Vincent, A., Newsom-Davis, J., 1988. Plasma from myasthenia gravis patients reduces acetylcholine receptor agonist-induced Na+ flux into TE671 cell line. J Neuroimmunol 19, 141-148.

Lavrnic, D., Losen, M., Vujic, A., De Baets, M., Hajdukovic, L.J., Stojanovic, V., Trikic, R., Djukic, P., Apostolski, S., 2005. The features of myasthenia gravis with autoantibodies to MuSK. J Neurol Neurosurg Psychiatry 76, 1099-1102.

Lennon, V.A., Seybold, M.E., Lindstrom, J.M., Cochrane, C., Ulevitch, R., 1978, Role of complement in the pathogenesis of experimental autoimmune myasthenia gravis. J Exp Med 147, 973-983.

Lindstrom, J.M., Engel, A.G., Seybold, M.E., Lennon, V.A., Lambert, E.H., 1976a. Pathological mechanisms in experimental autoimmune myasthenia gravis. I1. Passive transfer of experimental autoimmune myasthenia gravis in rats with anti-acetylcholine recepotr antibodies. J Exp Med 144, 739-753.

Lindstrom, J.M., Lennon, V.A., Seybold, M.E., Whittingham, S., 1976b. Experimental autoimmune myasthenia gravis and myasthenia gravis: biochemical and immunochemical aspects. Ann N Y Acad Sci 274, 254-274.

Losen, M., Stassen, M.H., Martinez-Martinez, P., Machiels, B.M., Duimel, H., Frederik, P., Veldman, H., Wokke, J.H., Spaans, F, Vincent, A., De Baets, M.H., 2005. Increased expression of rapsyn in muscles prevents acetylcholine receptor loss in experimental autoimmune myasthenia gravis. Brain 128, 2327-2337.

Loutrari, H., Kokla, A., Tzartos, S.J., 1992. Passive transfer of experimental myasthenia gravis via antigenic modulation of acetylcholine receptor. Eur J Immunol 22, 2449-2452.

Luo, G.X., Victor, K., Chong, K., McNeeley, P., Ramirez, D., Preclaro, J., Linnik, M.D., Campbell, M.A., 2001. Identification of a peptide that protects the human acetylcholine receptor against antigenic modulation. J Immunol Methods 251, 177-186.

Martinez-Martinez, P., Losen, M., Duimel, H., Frederik, P., Spaans, F., Molenaar, P., Vincent, A., De Baets, M.H., 2007. Overexpression of rapsyn in rat muscle increases acetylcholine receptor levels in chronic experimental autoimmune myasthenia gravis. Am J Pathol 170, 644-657.

Papanastasiou, D., Poulas, K., Kokla, A., Tzartos, S.J., 2000. Prevention of passively transferred experimental autoimmune myasthenia gravis by Fab fragments of monoclonal antibodies directed against the main immunogenic region of the acetylcholine receptor. J Neuroimmunol 104, 124-132.

Patrick, J., Lindstrom, J., 1973. Autoimmune response to acetylcholine receptor. Science 180, 871-872.

Phillips, W.D., Vladeta, D., Han, H., Noakes, P.G., 1997. Rapsyn and agrin slow the metabolic degradation of the acetylcholine receptor. Mol Cell Neurosci 10, 16-26.

Richman, D.P., Agius, M.A., Kirvan, C.A., Gomez, C.M., Fairclough, R.H., Dupont, B.L., Maselli, R.A., 1998. Antibody effector mechanisms in myasthenia gravis. The complement hypothesis. Ann $N$ Y Acad Sci 841, 450-465.

Rodgaard, A., Nielsen, F.C., Djurup, R., Somnier, F., Gammeltoft, 5., 1987. Acetylcholine receptor antibody in myasthenia gravis: predominance of IgG subclasses 1 and 3. Clin Exp Immunol 67, 82-88.

Simpson, J.A., 1960. Myathenia gravis: a new hypothesis. Scottish medical journal 5, 419-436.

Souroujon, M.C., Pachner, A.R., Fuchs, S., 1986. The treatment of passively transferred experimental myasthenia with anti-idiotypic antibodies. Neurology 36, 622-625.

Tarrab-Hazdai, R., Aharonov, A., Silman, I., Fuchs, S., Abramsky, 0., 1975. Experimental autoimmune myasthenia induced in monkeys by purified acetylcholine receptor. Nature 256, 128-130. 
Toyka, K.V., Brachman, D.B., Pestronk, A, Kao, 1., 1975. Myasthenia gravis: passive transfer from man to mouse. Science 190, 397-399.

Toyka, K.V., Drachman, D.B., Griffin, D.E., Pestronk, A., Winkelstein, J.A., Fishbeck, K.H., Kao, I., 1977. Myasthenia gravis. Study of humoral immune mechanisms by passive transfer to mice. $N$ Engl J Med 296, 125-131.

Toyka, K.V., Lowenadler, B., Heininger, K., Besinger, U.A., Birnberger, K.L., Fateh-Moghadam, A., Heilbronn, E., 1980. Passively transferred myasthenia gravis: protection of mouse endplates by Fab fragments from human myasthenic IgG. J Neurol Neurosurg Psychiatry 43, 836-840.

Tuzun, E., Scott, B.G., Goluszko, E., Higgs, S., Christadoss, P., 2003. Genetic evidence for involvement of classical complement pathway in induction of experimental autoimmune myasthenia gravis. $\mathrm{J} / \mathrm{m}$. munol 171, 3847-3854.

Tzartos, S.J., Barkas, T., Cung, M.T., Mamalaki, A., Marraud, M., Orlewski, P., Papanastasiou, D., Sakarellos, C., Sakarellos-Daitsiotis, M., Tsantili, P., Tsikaris, V., 1998. Anatomy of the antigenic structure of a large membrane autoantigen, the muscle-type nicotinic acetylcholine receptor. Immunol Rev 163 , 89-120.

Tzartos, S.J., Cung, M.T., Demange, P., Loutrari, H., Mamalaki, A., Marraud, M., Papadouli, I., Sakarellos, C., Tsikaris, $V_{.}, 1991$. The main immunogenic region (MIR) of the nicotinic acetylcholine receptor and the anti-MIR antibodies. Mol Neurobiol 5, 1-29.

Tzartos, S.J., Lindstrom, J.M., 1980. Monoclonal antibodies used to probe acetylcholine receptor structure: localization of the main immunogenic region and detection of similarities between subunits. Proc Natl Acad Sci U SA 77, 755-759.

Tzartos, S.J., Seybold, M.E., Lindstrom, J.M., 1982. Specificities of antibodies to acetylcholine receptors in sera from myasthenia gravis patients measured by monoclonal antibodies. Proc Natl Acad Sci U S A $79,188-192$.

van der Neut Kolfschoten, M., Schuurman, J., Losen, M., Bleeker, W.K., Martinez-Martinez, P., Vermeulen, E., den Bleker, T.H., Wiegman, L., Vink, T., Aarden, L.A., De Baets, M.H., van de Winkel, J.G., Aalberse, R.C., Parren, P.W., 2007. Anti-Inflammatory Activity of Human IgG4 Antibodies by Dynamic Fab Arm Exchange. Science 317, 1554-1557.

Verschuuren, J.J., Graus, Y.M., Tzartos, S.J., van Breda Vriesman, P.J., De Baets, M.H., 1991. Paratope- and framework-related cross-reactive idiotopes on anti-acetylcholine receptor antibodies. $J$ Immunol 146, 941-948.

Wang, Z.Y., Qiao, J., Link, H., 1993. Suppression of experimental autoimmune myasthenia gravis by oral administration of acetylcholine receptor. J Neuroimmunal 44, 209-214.

Wang, Z.Z., Mathias, A., Gautam, M., Hall, Z.W., 1999. Metabolic stabillzation of muscle nicotinic acetylcholine receptor by rapsyn. J Neurosci 19, 1998-2007.

Wu, J.M., Wu, B., Miagkov, A., Adamı, R.N., Drachman, D.B., 2001. Specific immunotherapy of experimental myasthenia gravis in vitro: the "guided missile" strategy. Cell Immunol 208, 137-147. 
CHAPTERS

Table 1: Myasthenia gravis disease symptoms result from complement activation and antigenic modulation

\begin{tabular}{lll}
\hline Complement activation & Antigenic modulation & disease \\
\hline Yes & Yes & Yes \\
Yes & No & No \\
& Rapsyn overexpression & \\
& Monovalent lgG4 & No \\
No & Yes & \\
Complement depletion & & \\
Complement deficiency & & \\
\hline
\end{tabular}




$\begin{array}{cc}\text { IgG4 anti-AChR } & \text { IgG4 anti-X } \\ \text { monospociflc } & \text { momospoclfie } \\ \text { functionally bivalent } & \text { fanctionally bivalent }\end{array}$
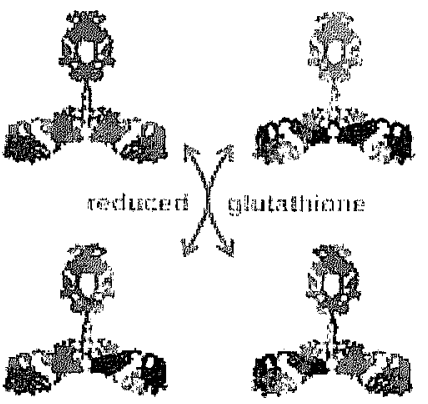

IgG4 anti-AChR / anti-X

bispecifle

functionally monovalent

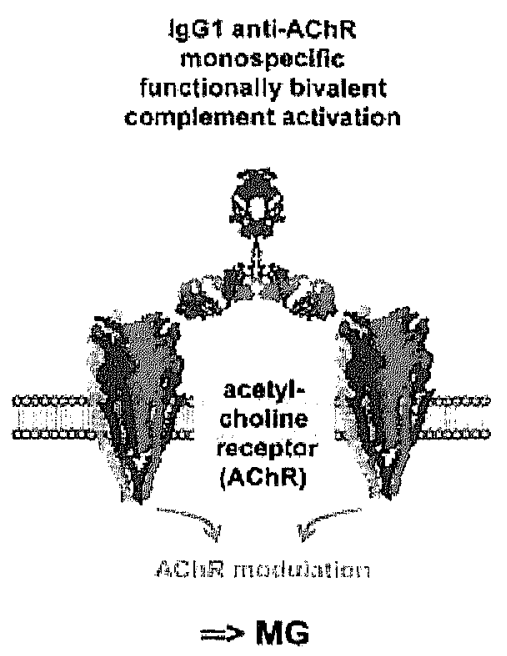

$\mathbf{E}$

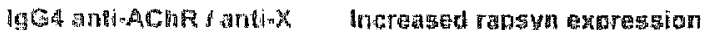
bispecific

functionally monovalent no complement activation

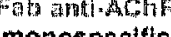
monovalent no complement activation

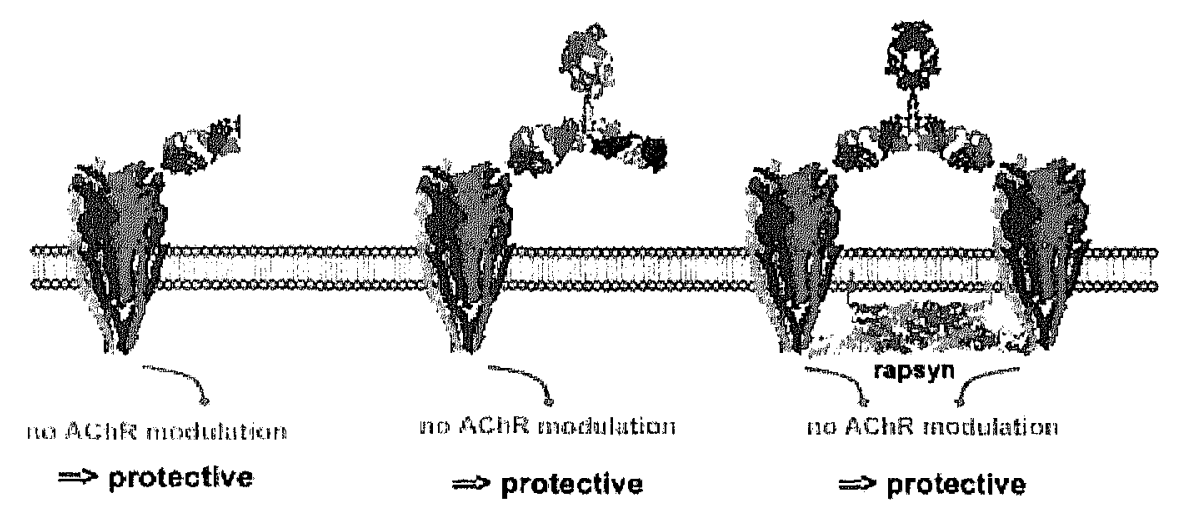

Figure 1. The role of complement and antigenic modulation in MG. (A) Two IgG4 molecules with different specificity interchange half molecules (one heavy and one light chain) resulting in bispecific antibodies. (B) effector mechanisms of lgG1 anti-AChR antibodies cause MG: bivalent and monospecific binding of IgG1 to the AChR leads to complement activation and cross-linking of two receptors. This results in antigenic modulation and internalization of the AChR. The MIR is shown in red. (C) Fab antibody fragments of anti-AChR antibodies can bind to the MIR and thereby prevent binding of full size anti-AChR antibodies. Fab antibody fragments do not activate complement and do not cross-link the AChR. (D) monovalent lgG4 molecules do not cross-link the AChR and can protect against IgG1 anti-AChR antibodies. (E) rapsyn anchors the AChR to the membrane and the cytoskeleton (not shown). Anchored AChRs are resistant to modulation by bivalent antibodies, even in the presence of activated complement. 


\section{Chapter 6}

\section{General Discussion}

Myasthenia gravis is an autoimmune disease caused by the failure of neuromuscular transmission as a result of antibody binding to mainly the acetylcholine receptor (AChR). Anti-AChR antibodies affect the neuromuscular transmission by three different mechanisms. The probably most important mechanism is the binding of antibodies which are able to activate the complement system and the formation of the membrane attack complex. Multiple studies suggest that complement activation at the NMJ might be the primary cause of AChR loss and failure of neuromuscular transmission. The second mechanism is antigenic modulation. Anti-AChR antibodies bind and cross-link AChRs at the NMJ. This leads to endocytosis of the receptors and their degradation. This results in a reduced number of AChRs and thus impaired neuromuscular transmission. The last effector mechanism of anti-AChR antibodies is binding to the acetylcholine binding site of the AChR causing a functional blockade. In chapter 1 we focus on a immunosuppressant drug which inhibits the production of AChR antibodies. Mycophenolate mofetil is a specific immunosuppressant which is able to inhibit the proliferation of lymphocytes. In chapter 2 we test another drug. The altered peptide ligand (APL) based on the $\alpha$-subunit of the acetylcholine receptor is not a classical suppressor of the immune system. Instead of inhibiting the immune response APL induces a Th1/Th2 shift resulting is a shift in IgG isotypes. This method has our particular interest because immunemodulation, in contrary to immunosuppression could promise a whole new strategy for the treatment of MG.

Chapter 3 focuses on CTLA-4 polymorphisms and their association with MG. CTLA-4 plays a key role function in the regulation of the immune response, probably by antagonism of CD28/B7-dependent stimulation of T-cells. Elucidation of the possible role of CTLA-4 in MG and how it influences the immune response might give us clues about how to manipulate these responses for a better treatment. 
In the first two chapters the role of the immune system in MG is discussed. In chapter 4 however, the focus lies on the response of the muscle on the immune response. The interaction of the AChR with the receptor-associated protein of the synapse (rapsyn) is pivotal for the integrity of the postsynaptic membrane. Gene therapy which increased rapsyn expression on the NMJ in vivo facilitated an increased resistance to EAMG. In chapter 4 the role of rapsyn in the maintenance of the adult NMJ by reducing rapsyn expression levels with short hairpin RNA (shRNA) was studied. We show that this results in a loss of AChR at the postsynaptic membrane. Surprisingly the muscle adapted to this reduction by rapidly producing postsynaptic folds to compensate for the AChR and rapsyn loss. The eminent role which rapsyn has for the integrity of the postsynaptic membrane is also studied in the last chapter. Increased expression of rapsyn prevents damage of the postsynaptic membrame by preventing antigenic modulation, even in the presence of the complement membrane attack complex.

Chapter 1 reviews the use of mycophenolate mofetil (MMF) in EAMG. Currently used non-specific immunosuppressive drugs often require intervention in myasthenia gravis (MG) and clinical improvement varies widely. To analyze the therapeutic effect of mycophenolate mofetil (MMF) in experimental autoimmune MG (EAMG), rats were immunized with acetylcholine receptors (AChRs) and subsequently treated with MMF or vehicle. MMF treatment resulted in a significant suppression of anti-rat AChR antibody titers. Interestingly, no abnormalities of neuromuscular transmission and adverse side effects were detected in MMF-treated EAMG animals. Moreover, anti-rat AChR antibody titers correlated to an improvement of clinical outcome. The data suggest that that MMF acts as a potent immunosuppressant drug in EAMG.

Chapter 2 describes the use an altered peptide ligand based on the $\alpha$-subunit of the acetylcholine receptor. Antibodies in $M G$ and in its animal model, experimental autoimmune myasthenia gravis (EAMG) are generally directed against the acetylcholine receptor. The $\alpha$-subunit of the acetylcholine receptor contains the immunodominant $T$ cell epitopes. We investigated if and by which mechanism an altered analog of two myasthenogenic peptides, p195-212 and p259-271, representing sequences of the acetylcholine receptor $\alpha$-subunit is able to modulate the autoimmune response in EAMG rats. The production of anti-acetylcholine receptorspecific antibodies was not affected by PTR262 in EAMG rats. Instead, PTR262 changed the isotype profile of the anti-acetylcholine antibodies; IgG1 autoantibodies were moderately increased, while lgG2b autoantibody levels were significantly decreased in PTR262-treated EAMG rats compared to untreated rats. Since all rat IgG antibody isotypes activate the complement system, the decrease of acetylcholine receptor in the muscles and the clinical EAMG symptoms were unaffected by the isotype shift. The results suggest that the mechanism by which PTR262 functions is by inducing a shift from a Th1 type immune response towards a 
Th2 type. In conclusion, these results indicate that PTR262 functions as an immune modulator with the capacity to alter the MG specific autoreactive immune response.

Chapter 3 reviews the association of CTLA-4 polymorphisms in myasthenia gravis patients. The CTLA-4 (CD152) gene at chromosome $2 q 33$ is expressed on the surface of activated T-cells. It plays an important role in the regulation of the immune response (Krummel and Allison, 1995). One proposed mechanism is antagonism of CD28/B7-dependent stimulation of T-cells. B7, which is presented on the surface of antigen presenting cells has a higher affinity for CTLA-4 than for CD28. A second mechanism is the negative signaling upon TCR activation, which leads to anergy of the T cells. The CTLA-4 gene displays several polymorphisms in the promoter region, i.e. $-1722 \mathrm{C} / \mathrm{T},-1661 \mathrm{~A} / \mathrm{G}$ and, (Hudson et al., 2002)-318 C/T (Deichmann et al., 1996), and a +49 A/G (Harper et al., 1991) polymorphism at exon 1. Polymorphisms in the CTLA-4 promoter region and in exon 1 influence surface expression of the receptor. Previous studies have shown CTLA-4 polymorphisms to be associated with several autoimmune diseases, including insulin dependent diabetes mellitus (IDDM), Graves' disease, Hashimoto's thyroiditis and rheumatoid arthritis (RA)

Wang and colleagues (Wang et al., 2002b) have shown a weak association of the $+49 \mathrm{~A} / \mathrm{G}$ genotype and $M G$ in a Swedish cohort of Swedish Caucasian patients. Another study reported an association of the $+49 \mathrm{~A} / \mathrm{G}$ genotypes and the occurrence of $M G$ in patients with thymoma. To study the association of genetic heterogeneity of the CTLA-4 gene in more detail, we determined $-1722 \mathrm{C} / \mathrm{T},-1661 \mathrm{~A} / \mathrm{G},-318 \mathrm{C} / \mathrm{T}$, and +49 A/G genotypes of 97 Dutch patients with serpositive MG and 168 healthy controls. In this study we found no association of any of the known CTLA-4 polymorphisms with $M G$.

In chapter 4 we investigated the effect of silencing rapsyn in vivo. Rapsyn is required for anchoring and stabilizing the nicotinic acetylcholine receptor (AChR) in the postsynaptic membrane of the neuromuscular junction (NMJ) during development. Here we studied the role of rapsyn in the maintenance of the adult NMJ by reducing rapsyn expression levels with short hairpin RNA (shRNA). Silencing rapsyn led to the average reduction of the protein levels of rapsyn (31\% loss) and AChR (36\% loss) at the NMJ within 2 weeks, corresponding to previously reported half life of these proteins. On the other hand, the sodium channel protein expression was augmented $(66 \%)$ in rapsyn-silenced muscles. Unexpectedly, at the ultrastructural level a significant increase in the amount of secondary folds of the postsynaptic membrane in silenced muscles was observed. The neuromuscular transmission in rapsyn-silenced muscles was mildly impaired. The results suggest that the adult NMJ can rapidly produce postsynaptic folds to compensate for AChR and rapsyn loss.

In chapter 5 we focus on the prevention of acetylcholine receptor modulation in myasthenia gravis. In myasthenia gravis antibodies directly bind to the acetylcho- 
CHates is

line receptor of the neuromuscular junction. The antibodies reduce the number of receptors by antigenic modulation and complement activation. These interdependent effector mechanisms lead to ultrastructural damage of the postsynaptic membrane and loss of receptor associated proteins. Functionally monovalent IgG4 antiacetylcholine receptor antibodies and increased expression of the receptor associated protein rapsyn prevent damage of the postsynaptic membrane by preventing antigenic modulation, even in the presence of the complement membrane attack complex. Therefore, the prevention of antigenic modulation can be used as a therapeutic strategy for the treatment of MG.

\section{References}

Deichmann, K., Heinzmann, A., Bruggenolte, E., Forster, J., Kuehr, J., 1996. An Mse I RF..P in the human CTLA4 promotor. Blochem Biophys Res Commun 225, 817-818.

Harper, K., Balzano, C., Rouvier, E., Mattei, M.G., Luciani, M.F., Golstein, P., 1991. CTLA-4 and CD28 actlvated lymphocyte molecules are closely related in both mouse and human as to sequence, message expression, gene structure, and chromosomal location. I Imnunol 147, 1037-1.044.

Hudson, L.L., Rocca, K., Song, Y.W., Pandey, J.P., 2002. CTLA-4 gene polymorphisms in systemic lupus erythematosus: a highly significant association with a determinant in the promoter region. Hum Genet $111,452-455$.

Krummel, M.F., Allison, J.P., 1995. CD28 and CTLA-4 have opposing effects on the response of $T$ cells to stimulation. J Exp Med 182, 459-465

Wang, X.B., Kakouliclou, M., Qiu, Q., Giscombe, R., Huang, D., Pirskanen, R., Lefvert, A.K., 2002. COS1 and promoter single nucleotide polymorphisms of the CTLA-4 gene in human myasthenia gravis. Genes Immun 3, 46-49. 


\section{List of publicators}

Published articles

Phernambucq, M., Janssen, S.P., Martinez-Martinez, P., De Baets, M.H., Losen, M., 2008. Immunosuppression of experimental autoimmune myasthenia gravis by mycophenolate mofetil. J Neuroimmunol 201-202, 111-120.

Losen, M., Martinez-Martinez, P., Phernambucq, M., Schuurman, J,, Parren, P.W., De Baets, M.H., 2008. Treatment of myasthenia gravis by preventing acetylcholine receptor modulation. Ann N Y Acad Sci 1132, 174-179.

Martinez-Martinez, P., Phernambucq, M., Steinbusch, L., Schaeffer, L., Berrih-Aknin, S., Duimel, H., Frederik, P., Molenaar, P., De Baets, M.H., Losen, M., 2009. Silencing rapsyn in vivo decreases acetylcholine receptors and augments sodium channels and secondary postsynaptic membrane folding. Neurobiol Dis 35, 14-23.

\section{Articles in Preparation}

Phernambucq M., Hamming A., Losen M., Martinez-Martínez P. Damoiseaux J., Losen M., Janssen S.P.M., van der Pol L., De Baets M.H. CTLA-4 polymorphisms are not associated with autoimmune myasthenia gravis in rats.

Phernambucq M., Janssen S. P.M., Martinez-Martinez P., De Baets M.H. and Mario Losen., Subcutaneous administration of an analog of two myasthenogenic peptides does not prevent experimental autoimmune myasthenia gravis in rats. 


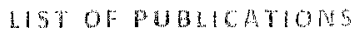

Abstracts and Poster presentations

M.Phernambucq, M. Losen, P.Martinez-Martinez, M.H.De Baets. The role of CTLA-4 polymorphisms in myasthenia gravis, 5 th Institutes day department Brain and Behaviour, University of Maastricht. January 2006 Maastricht, The Netherlands.

M.Phernambucq, Janssen S.P,M., M.Losen, P.Martinez-Martinez, M.H.De Baets. The effect on PTR262 on rats with Experimental Autoimmune Myasthenia Gravis. The $11^{\text {th }}$ International Conference on Myasthania Gravis and related disorders. May 2007, Chicago, USA.

M.Phernambucq, Janssen S.P,M., M.Losen, P.Martinez-Martinez, M.H.De Baets. The effect on PTR262 on rats with Experimental Autoimmune Myasthenia Gravis. Joint annual meeting of the Dutch society for immunology (NVVI), December 2007, Noordwijkerhout, The Netherlands.

M.Phernambucq, Janssen S.P,M., M.Losen, P.Martinez-Martinez, M.H.De Baets. The effect on PTR262 on rats with Experimental Autoimmune Myasthenia Gravis. $11^{111}$ Euron phD student meeting of the European Graduate school of neuroscience. Louvain, Belgum.

Pilar Martinez-Martinez, Losen, M., Phernambucq, M., Duimel, H., Frederik, P., Berrih-Aknin, S, Molemaar, P., Schaeffer, L., De Baets, M.H., Silencing Rapsyn in vivo decreases levels of AChR and causes hypertrophy of secondary membrane folding. The $11^{\text {th }}$ International Conference on Myasthania Gravis and related disorders. May 2007, Chicago, USA.

Janssen S.P,M., M.Phernambucq, M.Losen, P.Martinez-Martinez, M.H.De Baets. Mycophenolate mofetil suppresses the onset of experimental autoimmune myasthenia gravis. Belgian-Dutch Neuromuscular Study Club \& German Reference Center for Neuromuscular Disease of the DGNN, March 2007, Vaals, The Netherlands. 


\section{Achnowledsements}

Op het proefschrift dat nu voor u ligt staat slechts 1 naam vermeld. Die van ondertekende. Zoals $u$ wel begrijpen kunt doet dit geweld aan de werkelijkheid. Zoals ieder proefschrift, is ook dit proefschrift het resultaat van bloed, zweet, tranen, en een heleboel hulp van anderen. In wil hen hierbij dan ook bedanken want zonder hen had dit proefschrift nooit het levenlicht gezien.

Ik wil beginnen mijn promotor Marc De Baets te bedanken. Marc, zonder jou leiding, geduld en kennis was dit proefschrift er zeker niet geweest.

Ook mijn co-promotoren verdienen een prominente plek op deze bladzijde. Mario Losen wil ik bedanken voor de vele praktische zaken die hij mij geleerd heeft. Hij heeft mij ingewerkt op het lab en door de jaren heen heeft hij mij talloze technieken bijgebracht. Vooral zijn voorliefde voor technische uitdagingen op technisch en wetenschappelijk vlak zijn indrukwekkende kwaliteiten. Pilar Martinez wil ik bedanken voor haar hulp inzet en brede wetenschappelijke kennis die ze bereid was met mij te delen.

Harry Steinbusch, al weer 4 jaar terug waren jij en Marc degenen die mij een kans hebben gegeven om mij te bewijzen. Ik wil je voor die kans bedanken en voor het feit dat ik op een bruisende en steeds verder groeiende afdeling heb mogen werken die onder jou leiding zeker een mooie toekomst tegemoet gaat.

Sofie Janssen, ook jij verdiend hier zeker een plek. Hoewel het waarschijnlijk moeilijk is twee mensen te vinden met een karakter dat meer verschilt dan de onze ben ik blij met je te hebben samengewerkt. Af en toe werkte je me aardig op de zenuwen, maar altijd heb ik je directe eerlijkheid en resultaatgerichte manier van werken kunnen waarderen.

Verder wil ik mijn collega-AIO's en de masterstudenten in mijn vakgroep bedanken. Alejandro, Caroline, Chiara, Joost, Gerard, Kathleen. Bedankt voor jullie hulp, koffie en gezellige uurtjes. Zonder jullie allen waren de afgelopen jaren niet zo fijn geweest als dat ze nu waren. Ik zal onze "wetenschappelijke excursies" naar Newcastle en "Blankenberge" niet snel vergeten. Uiteraard wil ik jullie daarvoor bedanken, maar ook wil ik jullie bedanken voor jullie watenschappelijke input. Het was namelijk ontzettend plezierig om met jullie samen te werken. Caroline verdiend in deze nog een speciale vermelding als mijn gids in de Belgische cultuur en als "favoriete kamergenoot". Dat laatste is overigens een titel die ze moet delen met mijn andere 
kamergenoten; Tim, Mayienne, Gerard en Danielle. Jullie zorgden ervoor dat onze kamer op zijn minst een van de gezelligste van de afdeling was. Met veel plezier heb ik jusliie verhalen gehoord over jullie priveleven en wetenschappelijke beslommeringen.

Graag wil ik ook alle analisten bedanken met wie ik de afgelopen jaren heb mogen samenwerken. Marjo, Barbie, Jorike, Nicole, Hellen, Marianne. Jullie hebben als de smeerolie van ons lab geweldig werk verricht.

Verder gaat mijn dank uit naar mijn studiegenoten in de biomedische wetenschappen. Wendy, MJ, Martine, Josse ik vond het de afgelopen jaren heerlijk om in een ontspannen setting met jullie over wetenschap te kunnen discussiëren buiten mijn eigen vakgebied om. Door onze gesprekken kreeg ik altijd weer een nieuwe frisse kijk op mijn eigen onderzoek.

Mijn ouders verdienen hier natuurlijk ook een prominente plek. Zij zagen mij groeien van een klein jongetje dat in zijn Kwadendamse achtertuin zijn eigen experimenten bedacht tot de wetenschapper die ik nu ben. Een proces waarbij zij altijd voor honderd procent achter mijn zijn blijven staan en mij alle ruimte gaven om mezelf te kunnen ontwikkelen.

Verder wil ik eenieder bedanken die ik hier nog niet is vernoemd. Dat dat zijn op de eerste plaats al mijn collega's van de afdeling Neuroscience, maar ook iedereen buiten onze afdeling met wie ik ooit heb samengewerkt. Ik zal jullie allen erg missen nu ik mijn carrière op een andere plek voortzet.

Als laatste wil ik Rianne bedanken. Rianne, zonder jou was het mij niet gelukt. Je bent de afgelopen jaren mijn steun en toeverlaat geweest. Je hebt mij altijd aangemoedigd en vertrouwen gegeven. Misschien heb je soms gebaald in periodes dat ik lange dagen werkte en ik thuis te moe was om boe of bah te zeggen, maar altijd heb je begrip ervoor getoond. Samen met jou in Limburg wonen en werken was een superervaring. Ik hoop dat, nu we weer uit emigreren, onze volgende stap weer net zo'n mooie ervaring zal worden. 


\section{Curpriculum Witae}

Marko Alexander Phernambucq werd op 10 augustus 1979 geboren in Goes. Hij volgde het VWO op het Sint Willibrordcollege in Goes en haalde daar in 1997 zijn diploma. Na het VWO studeerde medische biologie hij aan de Universiteit Utrecht, waar hij in 2003 afstudeerde. Gedurende zijn studie volgde hij een stage op de afdeling pediatrische immunologie op het Wilhelmina Kinder Ziekenhuis (WKZ). Onder leiding van Dr. Ger Rijkers werkte hij daar aan een vaccin tegen longontsteking bij jonge kinderen. Dit vaccin is gebaseerd op het in vitro opnemen van bacteriële polysachariden door antigen-presenterende dendritische cellen. De presentatie van polysacharide fragmenten door dendritische cellen in de thymus zou zal bij jonge kinderen moeten leiden tot resistentie tegen longontsteking veroorzakende bacteriën.

Tijdens zijn studie deed hij verder een stage aan het Hubrecht Laboratorium in Utrecht (Nederlands Instituut voor Ontwikkelings Biologie). Onder leiding van Dr. Dana Jongejan-Zivkovic bestudeerde hij daar de rol van Wht genen in zebravissen met mutaties in het Wnt-pathway.

$\mathrm{Na}$ zijn afstuderen aan de Universiteit Utrecht werkte hij gedurende een jaar als onderzoeker aan de Universiteit van Amsterdam op de afdeling fysiologie. Hij deed daar electrofysiologisch onderzoek en analyseerde daar verschillende ion-stromen in SA-knoop cellen van de muis.

In 2005 begon hij als AIO aan de Universiteit Maastricht, waar hij 2 verschillende therapeutische behandelingen van myasthenia gravis bestudeerde in een ratmodel voor myasthenia gravis. Beide methodes zijn gebaseerd op immuunmodulatie van de immuunrespons die een rol speel bij myasthenia gravis. In een geval werd het peptide PTR262 getest in ratten met experimenteel geinduceerde myasthenia gravis. PTR262 induceert een verschuiving in het isotype antilichaam wat geproduceerd wordt. Hierdoor worden er minder complement bindende antilichamen aangemaakt die een pathologische immuunrespons of de neuromusculaire junctie veroorzaken. Het andere geteste medicijn, mycophenolaat mofetil remt specifiek de deling van lymfocyten. Hierdoor ontstaan er minder antilichaam producerende plasmacellen. Eveneens onderzocht hij tijdens zijn AlO periode het verband tussen SNP's in het CTLA-4 gen en myasthenia gravis. 


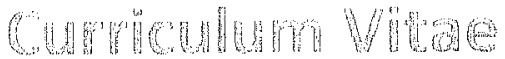

Marko Alexander Phernambucq was born in Goes, The Netherlands on August 10, 1979. He followed the VWO Sint Willibrordcollege in Goes where he graduated in 1997. After his secondary education he studied Medical Biology at the University of Utrecht were he graduated in February 2003. During his study he followed an internship in immunology at the Wilhelmina Pediatric Hospital (WKZ), were he under supervision of Dr. Ger Rijkers worked on a vaccine against pneunococcal bacteria which causes pneumoniae in young children. This vaccine is based on the in vitro loading of antigen presenting dendritic cells, with bacterial polysaccharides, If these dendritic cells are injected in vivo, they can induce resistance against pneumococcae in young children.

Furthermore he did a 9 months internship at the Hubrecht Laboratory in Utrecht (Dutch Institute for Developmental Biology) were he analysed the role of Wnt genes in zebrafish with mutations in the Wnt-pathway.

After his graduation at the University of Utrecht he worked for 1 year at the University of Amsterdam as a researcher at the department of Physiology. There he performed an electrophysiological analysis of mice sinoatrial node cells.

In 2005 he obtained a PhD position at the department of neuroscience in the Maastricht University were he studied 2 novel therapeutic drugs approaches for Myasthenia Gravis in an experimental rat model for myasthenia gravis. These potential treatments are based on immunomodulation of the immunerespons, which is responsible for the clinical manifestation of myasthenia gravis. One of these new drugs, PTR262 induces a shift in antibody isotype production, thus preventing a complement activated pathological immuneresponse at the neuromuscular junction. The other drug, mycophenolate mofetil specificly inhibits the proliferation of lymphocytes, and thus preventing the creation of antibody producing plasmacells. Furthermore he studied connection between between SNPS in the CTLA.4 gene and myasthenia gravis. 